\title{
First Year Student Expectations: General Education Goals at a Multi-Campus Community College
}

\author{
Sherri Anna Robinson \\ West Virginia University
}

Follow this and additional works at: https://researchrepository.wvu.edu/etd

\section{Recommended Citation}

Robinson, Sherri Anna, "First Year Student Expectations: General Education Goals at a Multi-Campus Community College" (2011). Graduate Theses, Dissertations, and Problem Reports. 3553.

https://researchrepository.wvu.edu/etd/3553

This Dissertation is protected by copyright and/or related rights. It has been brought to you by the The Research Repository @ WVU with permission from the rights-holder(s). You are free to use this Dissertation in any way that is permitted by the copyright and related rights legislation that applies to your use. For other uses you must obtain permission from the rights-holder(s) directly, unless additional rights are indicated by a Creative Commons license in the record and/ or on the work itself. This Dissertation has been accepted for inclusion in WVU Graduate Theses, Dissertations, and Problem Reports collection by an authorized administrator of The Research Repository @ WVU.

For more information, please contact researchrepository@mail.wvu.edu. 
First Year Student Expectations:

General Education Goals at a Multi-Campus Community College

\author{
Sherri Anna Robinson
}

Dissertation submitted to the

College of Human Resources and Education at

West Virginia University

in partial fulfillment of the requirements

for the degree of

Doctor of Education in

Educational Leadership

Elizabeth Jones, Ph.D., Chair

Ernest Goeres, Ph.D.

Richard Walls, Ph.D.

Patricia Obenauf, Ed.D.

Susan Aloi, Ed.D.

Department of Educational Leadership Studies 


\section{ABSTRACT \\ First Year Student Expectations: \\ General Education Goals at a Multi-Campus Community College \\ Sherri Anna Robinson}

In recent years, there has been a focus on the importance of general education in colleges and universities as a means of delivering a quality liberal education. Completion of a general education curriculum in the community college is required for successful completion in all associate degree programs. As more students are choosing community colleges to begin their studies, their general education experiences may affect their successful transfer to the baccalaureate, performance in the future workforce and participation as educated citizens.

Unfortunately, students have described general education as "a barrier" to their major or courses to "get of the way." At the same time, research has also shown that students value college outcomes (connected to study in general education) as being important. However, most research has been inclusive of students only at baccalaureate colleges and universities.

In this study, the College Student Expectations Questionnaire (CSXQ) was administered to first time students enrolled in Student Development courses at five campuses of a large suburban community college. Students expected the community college to moderately emphasize college activities that develop general education goals. They expected to participate often in college activities pertaining to Information Literacy, Communication, and Critical Thinking. They expected to occasionally participate in activities related to Cultural and Social Understanding, Quantitative Reasoning, and Scientific Reasoning. Significant differences in expected quality of effort were found based on College Opinion, Academic Major, Parents' Education, and Employment. 


\section{ACKNOWLEDGEMENTS}

I would like to dedicate this dissertation to my parents, the late Shirley Martin, Sr. and the late Anna Saunders Martin. You always encouraged me to do my best, supported my interests, and gave me the confidence that I could succeed not only in education but in life. My daughter, Anna, has been my biggest cheerleader throughout this process. I look forward to spending more time with you now that my dissertation journey is ending! I would also sincerely like to thank and acknowledge my family and friends for their support. When I needed to travel to class or conduct my research, it was a great comfort to know that she was with family and close friends that cared about her and as well as my success as a doctoral student. I would particularly like to thank: Joanne Martin, Rochelle Martin, Jerome Martin, Shirley Martin, Sr., Kimberly Wright and Schyla Pondexter-Moore.

I would especially like to thank my current WVU Educational Leadership Cohort family: Twyla Jones, Michael Turner, Michelle Ellis-Young, Trina Yearwood, Joyce Herold and Gabrielle St. Leger. Our travels through West Virginia I will never forget! Your support as colleagues and friends made this dissertation journey special and memorable. I would also like to sincerely thank Jennifer McIntosh in the WVU Office of Social Justice for encouraging me to come to WVU and your continued support throughout the program.

I would like to thank Dr. Cynthia Greer, my former faculty advisor and professor at Trinity Washington University. You provided my introduction to student affairs and higher education leadership. You have also been a wonderful mentor and supportive in all of my endeavors.

The encouragement of my colleagues at Northern Virginia Community College was very instrumental throughout my doctoral program and the success of my dissertation research. 
Kimberly Ellis and Raymond Jones, thanks for your support and friendship throughout this process! Kerin Hilker and Tanya Ingram, thanks for your cooperation and assistance with the students and faculty involved in this study. I would also like acknowledge Dr. John Thrash, Jr., former Dean of Students (Annandale Campus), Dr. Sharon (Sheri) Robertson, Associate Vice President for Academic Services, and Dr. George Gabriel, Vice President of the Office of Research, Assessment, and Planning for their guidance in developing my interests into this research study. I would especially like to thank Dr. John Dever, Executive Vice President for Academic and Student Services, Dr. Robert Templin, Jr., President of Northern Virginia Community College and Dr. Glenn DuBois, Chancellor of the Virginia Community College System (VCCS) for their recommendation and selection as a VCCS Faculty Fellow for the 20102011 academic year. The educational leave and stipend provided by this wonderful professional development opportunity was extremely instrumental in my ability to complete my doctorate program this semester.

Finally, I would like to thank my committee for your guidance in my dissertation journey. The advice and support of my advisor, Dr. Elizabeth Jones has been invaluable not only as a doctoral student but as a higher education professional. I appreciate Dr. Ernest Goeres for always lending a helping hand with dissertation advice as well as with administrative support on campus. I would like to thank Dr. Richard Walls for being so prompt with feedback and always taking what I presented and making it better. Dr. Patricia Obenauf, thank you for being so thoughtful and making what initially seemed to be an intimidating dissertation process more of a supportive relationship. Dr. Susan Aloi, thanks for being one of my best graduate school instructors ever! The knowledge that I gained from your courses in Assessment and Assessment Research definitely shaped my professional interests! 


\section{TABLE OF CONTENTS}

Acknowledgements......................................................

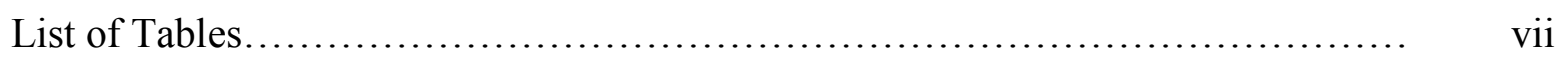

Table of Figures..................................................... xii

CHAPTER ONE: Statement of the Problem................................ 1

Purpose Statement.................................................. 3

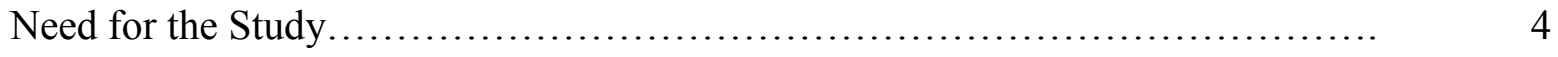

Delimitations..................................................... 10

Organization of the Dissertation....................................... 10

Definitions of Terms.................................................... 11

CHAPTER TWO: Review of the Literature.................................. 13

Theoretical Models Related to Student Effort and Persistence................... 13

Community College Student Expectations............................... 22

Essential College Outcomes............................................ 24

Community Colleges and General Education.............................. 38

College Student General Education Experience............................ 40

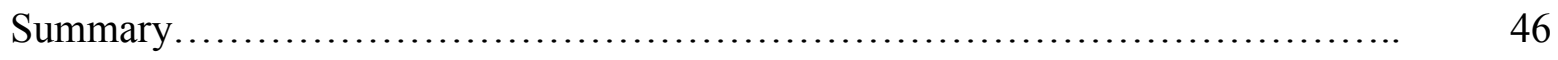

CHAPTER THREE: Research Design and Methods.......................... 48

Introduction........................................................ 48

Method: Qualitative Research Design.................................... 48

Data Collection Procedures............................................ 53

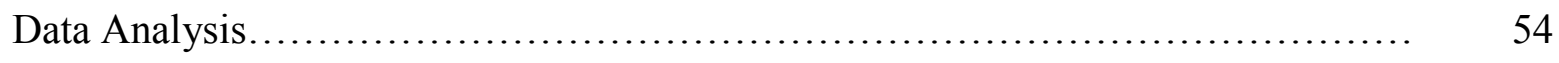

Limitations......................................................... 61 
CHAPTER FOUR: Results........................................... 62

Overview......................................................... 62

Survey Process ................................................... 62

Respondent Characteristics............................................ 62

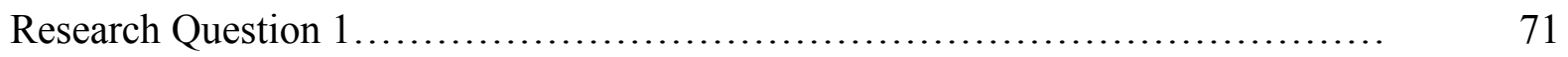

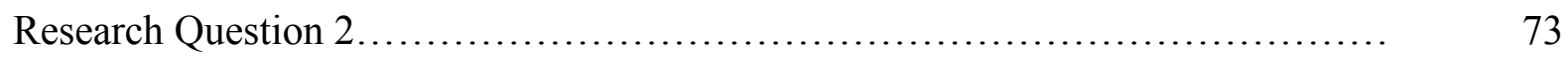

Research Question 2A Parents' Education................................ 76

Research Question 2B: Employment.................................. 84

Research Question 2C: College Opinion................................. 91

Research Question 2D: Academic Major................................ 110

CHAPTER FIVE: Summary, Conclusions, and Recommendations................ 129

Overview........................................................ 129

Summary of Results.............................................. 129

Conclusions......................................................... 141

Environmental Emphasis.............................................. 141

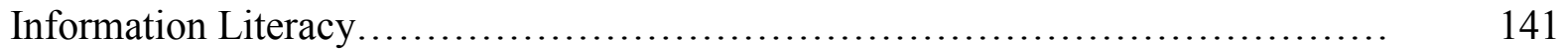

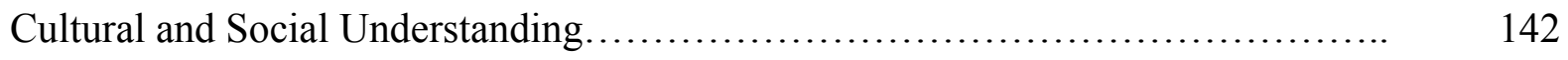

Quantitative and Scientific Reasoning................................... 143

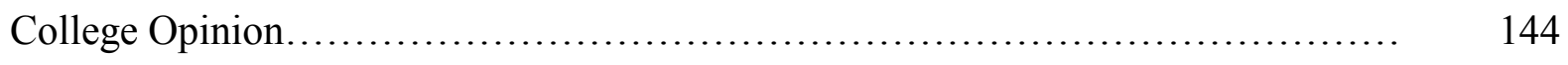

Recommendations for Practice........................................ 144

Enhancing College Marketing Materials................................... 144

Coordinating First Year Experience Programs................................ 145

Enhancing Academic Advising Services.................................... 147 
Making Science and Mathematics Relevant................................. 148

Recommendations for Research........................................ 149

Investigating Significant Differences by Race and Ethnicity..................... 149

Conducting Qualitative Research on College Opinion............................ 150

Studying the Quality of Effort on Community College Students................... 151

Investigating Community College Student Expectations and Experiences............ 152

Conducting Qualitative Research on General Education in Community Colleges........ 152

References............................................................ 153

APPENDIX A: College Student Expectations Questionnaire (CSXQ)............... 165

APPENDIX B: Approval for Dissertation Research Study by Participating Institution... 169

APPENDIX C: Cover Letter to Participants................................... 170 


\section{LIST OF TABLES}

Table 1: The AAC\&U LEAP Initiative's Essential Learning Outcomes (2002)........ 25

Table 2: Areas of Knowledge and Intellectual Skills/Ability Identified by AAC\&U Member

Institutions as Common Learning Goals....................................... 26

Table 3: Shared Highest and Lowest Ratings of HBCU and Non-HBCU Students from the

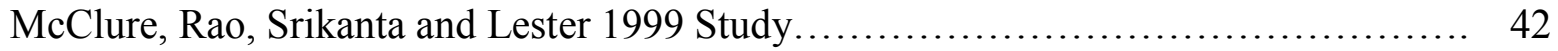

Table 4: Top Tier College Outcomes of Wisconsin (2005) and Indiana, Oregon \& Virginia

(2004) Focus Group Participants......................................... 43

Table 5: Participating Sections of Student Development (SDV) in Dissertation Study... 50

Table 6: MCC's General Education Goals and Related CSXQ

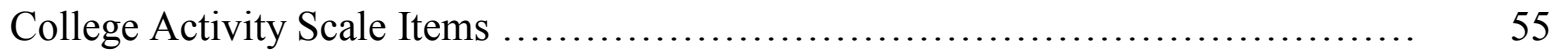

Table 7: Research Questions 2A-D Variables and Analysis..................... 60

Table 8: Age of Participating Students.................................... 63

Table 9: Gender of Participating Students.................................. 63

Table 10: Response to Student Characteristics: Racial/Ethnic Identification.......... 64

Table 11: Parents' Education for Participating Students........................ 65

Table 12: Residence of Participating Students............................... 65

Table 13: Enrollment Characteristics for Participating Students.................... 66

Table 14: Semester Credit Hour Enrollments of Participating Students............. 66

Table 15: Work Hours On-Campus of Participating Students.................... 67

Table 16: Work Hours Off-Campus of Part-time Students........................ 67

Table 17: College Funding of Participating Students........................... 68

Table 18: Intended Academic Major of Participating Students..................... 69 
Table 19: Expected Hours Spent on Outside Class Activities......................... 70

Table 20: Expected Grade Point Average of Participating Students.................... 71

Table 21: Interest in Advanced Degree of Participating Students...................... 71

Table 22: Environmental Emphasis on General Education Goals....................... 72

Table 23: CSXQ Means: Environmental Emphasis on General Education Goals......... 73

Table 24: CSXQ Means of the College Activity Items Related to

General Education Goals........................................................ 74

Table 25: Means, Standard Deviations, and One-Way Analysis of Variance for the Effects of Parents' Education on Information Literacy CSXQ Variables........................... 77

Table 26: Means, Standard Deviations, and One-Way Analysis of Variance for the Effects of Parents' Education on Communication CSXQ Variables............................. 78

Table 27: Means, Standard Deviations, and One-Way Analysis of Variance for the Effects of Parents' Education on Critical Thinking CSXQ Variables............................. 79

Table 28: Means, Standard Deviations, and One-Way Analysis of Variance for the Effects of Parents' Education on Cultural and Social Understanding CSXQ Variables.............. 80

Table 29: Means, Standard Deviations, and One-Way Analysis of Variance for the Effects of Parents' Education on Quantitative Reasoning CSXQ Variables...................... 82

Table 30: Means, Standard Deviations, and One-Way Analysis of Variance for the Effects of Parents' Education on Scientific Reasoning CSXQ Variables......................... 83

Table 31: Means, Standard Deviations, and One-Way Analysis of Variance for the Effects of Parents' Education on Quantitative/Scientific Reasoning CSXQ Variables............. 84

Table 32: Means, Standard Deviations, and One-Way Analysis of Variance for the Effects of Off-Campus Employment on Information Literacy CSXQ Variables................... 85 
Table 33: Means, Standard Deviations, and One-Way Analysis of Variance for the Effects of Off-Campus Employment on Communication CSXQ Variables 86

Table 34: Means, Standard Deviations, and One-Way Analysis of Variance for the Effects of Off-Campus Employment on Critical Thinking CSXQ Variables 87

Table 35: Means, Standard Deviations, and One-Way Analysis of Variance for the Effects of Off-Campus Employment on Cultural and Social CSXQ Variables. 88

Table 36: Means, Standard Deviations, and One-Way Analysis of Variance for the Effects of Off-Campus Employment on Quantitative Reasoning CSXQ Variables.... 90

Table 37: Means, Standard Deviations, and One-Way Analysis of Variance for the Effects of Off-Campus Employment on Scientific Reasoning CSXQ Variables. ... 90

Table 38: Means, Standard Deviations, and One-Way Analysis of Variance for the Effects of Off-Campus Employment on Quantitative/Scientific Reasoning CSXQ Variables.... 91

Table 39: Means, Standard Deviations, and One-Way Analysis of Variance for the Effects of College Opinion on Information Literacy CSXQ Variables 94

Table 40: Means, Standard Deviations, and One-Way Analyses of Variance for the Effects of College Opinion on Communication CSXQ Variables 96

Table 41: Means, Standard Deviations, and One-Way Analysis of Variance for the Effects of College Opinion on Critical Thinking CSXQ Variables. 99

Table 42: Means, Standard Deviations, and One-Way Analysis of Variance for the Effects of College Opinion on Cultural and Social Understanding CSXQ Variables 105

Table 43: Means, Standard Deviations, and One-Way Analysis of Variance for the Effects of College Opinion on Quantitative Reasoning CSXQ Variables 107 
Table 44: Means, Standard Deviations, and One-Way Analysis of Variance for the Effects of College Opinion on Scientific Reasoning CSXQ Variables.

Table 45: Means, Standard Deviations, and One-Way Analysis of Variance for the Effects of College Opinion on Quantitative/Scientific Reasoning CSXQ Variables. ... 110

Table 46: Means, Standard Deviations, and One-Way Analysis of Variance for the Effects of Academic Major on Information Literacy CSXQ Variables. 112

Table 47: Means, Standard Deviations, and One-Way Analysis of Variance for the Effects of Academic Major on Communication CSXQ Variables

Table 48: Means, Standard Deviations, and One-Way Analysis of Variance for the Effects of Academic Major on Critical Thinking CSXQ Variables.

Table 49: Means, Standard Deviations, and One-Way Analysis of Variance for the Effects of Academic Major on Cultural and Social Understanding CSXQ Variables. 118

Table 50: Means, Standard Deviations, and One-Way Analysis of Variance for the Effects of Academic Major on Quantitative Reasoning CSXQ Variables. 122

Table 51: Means, Standard Deviations, and One-Way Analysis of Variance for the Effects of Academic Major on Scientific Reasoning CSXQ Variables. 125

Table 52: Means, Standard Deviations, and One-Way Analysis of Variance for the Effects of Academic Major on Quantitative/Scientific Reasoning CSXQ Variables.

Table 53: Total General Education CSXQ Items with Significant

Differences in Group Means.

Table 54: CSXQ General Education Items Indicating Significant Differences or Strong Trends in Group Means Based on Parents' Education, Employment, College Opinion and Academic Major 134 


\section{TABLE OF FIGURES}

Figure 1. Employers' Top Priorities for Student Learning in College ................... 9

Figure 2. Path for a Student Development and College Impress Model................ 16 


\section{CHAPTER ONE}

\section{Statement of the Problem}

More than 35\% of our nation's undergraduates chose to enroll in community colleges during the fall of 2006 (Provasnik \& Planty, 2008). Considering the current challenging economic times for our country, students and their families are realizing the lowered tuition rates and overall savings in completing an associate's degree and then transferring for the completion of a bachelor's degree. Also, students with financial and family responsibilities consider the flexibility of scheduling in community colleges to be an attractive option for pursuing their higher education goals while they remain employed.

Historically, community colleges provide open access to all who are interested in pursuing an education. They have also been the gateway for students who were academically underprepared to have a place in higher education or were denied access to their university of choice. Approximately $29 \%$ of beginning students who enter community colleges reported that they have enrolled in developmental writing, reading, and mathematics in their first year of coursework (Provasnik \& Planty, 2008). Community colleges have answered the call to provide developmental education courses to prepare students for college level coursework and pursuit of a degree. Students who were unsuccessful in their attempts for admission to (or being able to afford) their four-year school of choice will often consider their local community college. These students have options of beginning their higher education careers and transferring early or completing the associate's degree to take advantage of guaranteed admissions/articulation agreements with four-year institutions.

General education courses are a major part of the curriculum and the associate degree programs provided by community colleges. In many of the transferable associate degrees 
(Associate of Arts/Associate of Science), general education courses will comprise the majority of their coursework where students will take few (if any) major area courses until after transfer to the four year institution. In the occupational degrees (Associate of Applied Arts/Associate of Applied Science), students are heavily introduced to their career courses; however, there is an expectation that students also complete general education courses to satisfy their degree requirements. If students are unable to complete their general education courses at the community college, then it is unlikely that they will complete an associate's degree.

Many students attend a community college because they want to complete a certificate program or an associate's degree that is very career oriented. These students may see general education courses as a means to an end-"something to get out of the way" or "a barrier." However, most colleges and universities focus on the following college outcomes: communication, information literacy, global understanding, and quantitative reasoning which are designed to provide college graduates with the skills, knowledge and abilities that will enhance education beyond their major, their position in the workforce, and as citizens. The general education goals at most community colleges are realized through study in general education courses found in the distribution models where students will select from courses to meet degree requirements for graduation (i.e. Humanities, Social Sciences, Physical/Life Sciences, and Mathematics) (Path \& Hammons, 1999; Schuyler, 1999; Zeszotarski, 1999). However, we have little understanding of what community college students' perceptions are about the learning goals of general education, whether they feel they are important, and the expectations of the community college to provide that educational experience. There is also a lack of information about how general education is communicated to community college students and what ways students learn about the meaning behind general education requirements. 
The Association of American Colleges and Universities (AAC\&U) has taken special interest with its ten year campaign called LEAP-Liberal Education and America's Promise in promoting the value of liberal education. AAC\&U commissioned a series of focus groups consisting of college-bound high school students and college juniors and seniors focusing on their definitions and perceptions of liberal education as well as important college outcomes (Hart Research Associates, 2005; Hart Research Associates, 2004). Although the study was able to provide very useful data about students' opinions regarding the lack of communication and understanding about liberal education goals, it did not include community college students.

There is a lack of research that asks community college students how they feel about the general education goals that are to be studied in their collegiate experience. From the small amount of studies that are available, most of the current research is not inclusive of community college students populations. The literature on this topic consists of single university studies of student satisfaction or perceptions of general education goals, programs or its specific components (Anderson, et al., 2007; Harmes \& Miller, 2007; House, 2006; Dallinger \& Mann, 2000). One study also compared the students' attitudes towards general education attending historically black colleges and universites (HBCU's) and non-HBCU institutions (McClure, Rao, \& Lester, 1999). As students have developed opinions and attitudes towards general education, it is important to investigate expectations regarding this portion of the curriculum.

\section{Purpose Statement}

The purpose of this study was to determine first year student expectations of general education goals at a large multi-campus urban community college. The research questions in the study were: 
1. What general education goals do students expect to be emphasized in the community college environment?

2. How much effort do students expect to apply toward general education goals?

a. Are there significant differences between expectations of community college students based upon parent educational attainment?

b. Are there significant differences between the expectations of community college students based upon the number of hours working off campus?

c. Are there significant differences between the expectations of community college students based upon their opinion of college?

d. Are there significant differences between the expectations of community college students based upon their intended academic major?

Studies conducted in the 1980s and 1990s have documented students' perceptions of general education outcomes through institutional assessments where current students or graduates reported whether or not they improved certain competencies, skills or met certain learning objectives. There is little research regarding how community college students perceive general education requirements today.

\section{Need for the Study}

This dissertation research study has significant importance for college administrators, faculty members, and student affairs professionals. College administrators and faculty have the responsibilities of developing curriculum with multiple constituencies including state boards, accrediting bodies, business/industry and others; however the most important constituent is the student learner. Knowing student expectations about the general education goals of an institution can assist in developing various ways to introduce the curriculum, communicate expectations 
about learning, and clarify the importance of general education early in their collegiate experience.

Without clear statements about general education's purpose at the community college, there is no basis for guiding students. As many students seek counseling/advising services as they begin college, they initially rely upon faculty/staff who they perceive as the expert authority for advice on course selection. These individuals may hear about student frustrations concerning their academic adjustments in college and students may question the purpose of taking courses such as English, social science, mathematics, speech and other categories of the college distribution requirement. Inconsistencies in messages confuse college students as they may receive several, and often conflicting, answers from different individuals on campus, other students or family members. In some cases, students may come to erroneous conclusions (i.e. the college is making us take these courses to get more tuition or to fill classes that would otherwise be closed).

With $45 \%$ of community college students leaving school without reaching their goals of graduation and transfer to a four year school, we have to inquire as to whether their perception of the curriculum is part of the problem (Provasnik \& Planty, 2008). In his speech at Macomb Community College on July, $21^{\text {st }} 2009$, President Barack Obama stated that:

If a parent is going to spend time in the classroom and away from his or her familyespecially after a long day at work-that degree has to mean something. They have to know that when they get that degree, this is going to help advance their goals. If a worker is going to spend two years training to enter a whole new profession, that certificate has to mean that he or she is ready, and that businesses are ready to hire. 
This study is timely as more attention is being directed towards increasing the success rates of community college students nationwide with the American Graduation Initiative introduced by President Obama. As more of the nation's citizens choose to enter the community college, the increase in attrition may have a devastating effect on the economy and job market as the credential of the associate's degree becomes more in demand (over just a high school education). Also the individual economic constraints of students will not disappear as they will have to pay back debt for a degree never completed or use a significant amount of their income to pay for school without graduating.

Major challenges are faced by community college students including financial issues, social integration and transfer concerns; however, academic integration including the courses that are available to students, what they learn and in what context, does affect student satisfaction and persistence (Tinto, 1975, 1987, 1993; Bean and Metzner, 1985; Braxton, Hirschy \& McClendon, 2004). Students with transfer goals may decide to leave community college without the associate's degree (affecting the retention rate) if they are not satisfied with the community college curriculum. Students who have clear occupational goals may question why they have to dedicate so much of their time to studying "outside of their major," particularly if they are not successful. These students may drop out or consider other post-secondary options such as vocational schools or vocationally-oriented proprietary colleges/universities where less liberal arts courses are required.

Students' values and interests can also have an effect on their quality of effort in the collegiate environment (Pace, 1979, 1984). College students in academic and vocational programs may not participate in active learning experiences within courses but only retain enough information to pass the class and move on, particularly if they feel that general education 
is a waste of their time. One of the major benefits of graduating from a community college is that many universities will waive general education requirements for students with associate degrees, particularly if articulation agreements are in place. Articulation agreements between many community colleges and public/private colleges and universities arrange for a transition of community college graduates as juniors. Detailed agreements provide current community college students and counselors with transfer guides (printed and online) which specifically provide a list of courses for students to complete. These courses are typically centered on a liberal arts curriculum with the intent that the majority of major area courses are to be taken after transfer.

However, without a strong mastery of key competencies, community college graduates (even with high grade point averages) who successfully transfer may experience academic difficulties at the four-year institution. General education competencies may be assessed in major area courses or some universities may have a continuation of upper-level general education courses in the junior and senior years. The reputation of the community college is called into question if those transfer students cannot perform at the level expected by university faculty. Transfer may also pose challenges with the social integration of students who viewed the community college purpose as strict training for transfer/occupational interests only. Receiving universities may have a strong mission to develop citizenship, cultural literacy and global understanding of their graduates which could provide a change from the previous environment of transfer students.

There are implications for the workforce as well for those students who decide to pursue employment after graduation from a community college. Beyond the technical skills that are required for employment in a new global economy, businesses are seeking to recruit college graduates who have strong abilities in such areas as problem-solving, analytic thinking skills, 
time management skills, teamwork, communications, leadership, learning, and systems thinking (Jones, 2002; Hart Research Associates, 2006; Hart Research Associates, 2010). In the most recent research of the Association of American Colleges and Universities (AAC\&U) called "Raising the Bar: Employers' Views of Economic Learning in the Wake of the Economic Downturn," three hundred and two executives were interviewed from public and non-profit organizations (see Figure 1). The majority of respondents believed that two-year and four-year institutions need to make some improvements in preparing students for a global economy. Over $80 \%$ of respondents reported that colleges should place more emphasis on helping students develop oral/written communication and critical thinking/analytical reasoning skills (Hart Research Associates, 2010).

The core curriculum, along with improved pedagogy, helps students develop these skills. However, without active student participation and effort, they may not work as hard to build the competencies that are expected by employers. Instead, students may just put forth enough effort in courses to only receive a passing grade and receive a degree, but have limited skills needed to successfully maintain themselves in a longstanding career.

The results of the AAC\&U study challenges community colleges to prepare an action plan to address how the general education curriculum should be communicated to students. Once it is revealed how students perceive general education outcomes, colleges can develop ideas on how to promote the importance of the knowledge and competencies students should be able to demonstrate. Community colleges can work to develop methods to motivate students and their interest in learning by showing a connection between those general education courses and their career objectives/major in a meaningful way. 


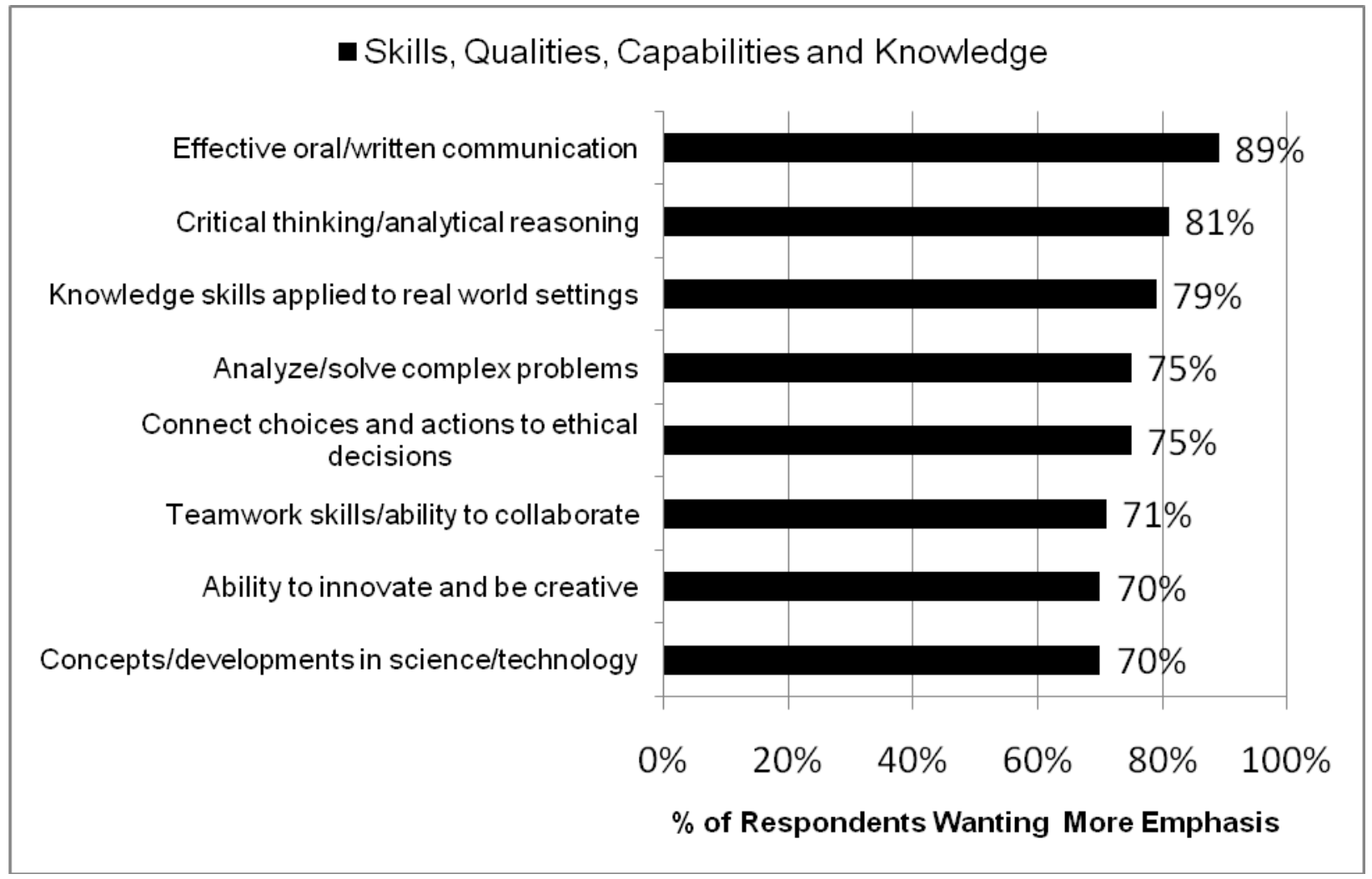

Figure 1. Employers' Top Priorities for Student Learning in College (Hart Research Associates, 2010). Adapted from "Raising the Bar: Employers' Views on College at the Wake of the Economic Downturn” by Hart Research Associates, 2010.

Finally, the access to a quality general education program has a direct connection with social equity. Community colleges have historically served at-risk populations (inclusive of lower income, minority and disabled students) by providing open admissions and relatively inexpensive options for higher education. Currently, they have larger percentages of nontraditional, lower-income, and minority students than do four year universities (Horn \& Griffith, 2006; Provasnik \& Planty, 2008). If university students are more likely than community college students to be provided with clear expectations and messages about the value of general education (as well as access to a curriculum that reflects those general education goals), then inclusiveness and equal access for all students through education will become less 
obtainable for the underprivileged (Tsui, 2003). The class divide allows for "higher-class elites who matriculate at four-year colleges and universities, and thus obtain the credentials necessary for coveted leadership positions in our society" (Sacks, 2009, p. 16).

\section{Delimitations}

The delimitations of the study are as follows:

1. The survey was administered at one large suburban multi-campus community college which can be applicable to community colleges with similar institutional characteristics.

2. The study was limited to a sample of convenience of students enrolled in Student Development courses which targets a population of students enrolled in AA, AS, AAA, or AAS degree programs and certificate programs.

3. Students' perceptions may change over time. This survey instrument measures their current perceptions which can change upon entry or exit into specific courses or the college.

\section{Organization of the Dissertation}

The second chapter of the dissertation consists of the literature review and is comprised of five sections. The first section reviews two relevant models: Pace's Path for a Student Development and College Impress Model $(1979,1984)$ and Tinto's Longitudinal Model of Departure from Institutions of Higher Education $(1975,1987,1993)$. Pace's model is discussed to provide an understanding of how the effort that students apply towards their college experience affects their growth and development in college. The College Student Expectations Questionnaire (CSXQ) is discussed as a companion to Pace's model commonly referred to as the Quality of Effort theory. Next, Tinto's model provides an explanation of how students' dissatisfaction with the academic components or lack of academic integration impacts their 
decision to either persist or withdraw. Other theories which build upon Tinto are discussed because of their relevancy with the community college population including Bean and Metzner (1985), and Braxton, Hirschy and McClendon (2004). The second section discusses the research on what community college students expect as a result of their college experience. The third section provides an overview of the literature on the college outcomes/skills identified as being essential in today's workforce including: writing, critical thinking, quantitative reasoning, oral communication, intercultural skills, information literacy, ethical reasoning and civic engagement. The fourth section describes the general education curriculum in community colleges which is used to develop the essential college outcomes. The final section discusses the literature on students' perceptions of the general education curriculum which reveals a disconnection between the general education goals and their actual experiences.

The methodology is described in Chapter Three which provides the research design, selected participants, description of the instrument, data collection procedures, data analysis, and limitations of study. Chapter Four will explain the data analysis and report the results. Chapter Five will summarize the study, discuss implications for practice, and recommend future community college research. The survey instrument and cover letters seeking approval and participation will be attached to the dissertation as appendices.

\section{Definitions of Terms}

The following are some examples of definition of terms used in the dissertation:

Community College-an institution of higher education that awards the associate's degree as the highest degree. The term "two year college" is not used in this dissertation as many community college students are part time and do not complete the associate's degree in two years. 
Distribution Requirement- "These systems specify a number of courses to be taken within certain academic disciplines. For example, to fulfill the general education requirements, students must take two courses in each of the major academic divisions: social sciences, arts, humanities, and physical sciences. Unlike core curricula, distributional requirement programs do not prescribe a sequence of specific courses" (Zeszotarski, 1999, p. 41).

Liberal Education-“A philosophy of education that empowers individuals, liberates the mind from ignorance, and cultivates social responsibility" (Association of American Colleges and Universities, 2002, p. 25).

General Education- "The part of a liberal education curriculum shared by all students. It provides broad exposure to multiple disciplines and forms the basis for developing important intellectual and civic capacities" (Association of American Colleges and Universities, 2002, p. 25). General education is sometimes referred to as core, university or liberal arts/studies curriculum.

College Outcomes-the knowledge and skills that are expected from students or graduates as a result of their college attendance.

General Education Goals-college objectives that are a result of the study in the liberal arts or general education courses/curriculum.

College Student Expectations Questionnaire (CSXQ)-The second edition of the College Student Expectations Questionnaire (Pace \& Kuh, 1999) was derived from the fourth edition of the College Student Experiences Questionnaire (Pace \& Kuh, 1998). The CSXQ measures students' expectations for their first year of college and how they plan to spend their time in educationally purposeful activities. 


\section{CHAPTER TWO}

\section{Review of Literature}

This chapter will explore college student expectations and perceptions of general education outcomes, goals and related curriculum. In order to understand the impact of student expectations on the college experience, the first sections will provide an overview of relevant college impact models pertaining to student effort and retention. Pace's Path for a Student Development and College Impress Model (1979, 1984) and Vincent Tinto’s Longitudinal Model of Departure from Institutions of Higher Education $(1975,1987,1993)$ provides an understanding of how student experiences affect their quality of effort and decisions to withdraw from college.

Next, the relevant empirical literature surrounding several key issues will be explored. First, the review will provide an overview of the expectations of community college students and their reasons for choosing to attend. The top eight intellectual skills identified by the Association of American Colleges and Universities (AAC\&U) member institutions as common learning goals will be reviewed. Next, it will highlight the literature describing general education in community colleges to reveal how the learning outcomes are presented to students. The last section will explore undergraduate students' perceptions of their general education experiences to provide an understanding as to whether there is a connection or a mismatch between intent and reality.

\section{Theoretical Models Related to Student Effort and Persistence}

In order to understand how students view the curriculum, theories pertaining to how their perceptions will impact learning and their decision to persist in college are important to review. In describing the impact on student learning, Pace $(1979,1984)$ provides an overview of how the 
value students place on the curriculum will affect their effort and approach to learning. Tinto (1975, 1987, 1993) offers an understanding of the relationship between students' academic experiences and retention.

Pace's quality of effort theory. C. Robert Pace's $(1979,1984)$ model contributed to higher education literature by not only providing an understanding of students' learning and development in college but how the time and effort that students invest in college studies affect the attainment of student outcomes. Commonly referred to as the Quality of Effort Theory, Pace has three basic propositions: entrance, college events and experiences, and effort and environment. These propositions contribute to students' development and college impress (referring to mark or impression) as they exit college (see Figure 2).

Entrance measures provide insight as to where students begin their higher education. The criterion only covers areas that are subject to change as a result of college experiences (excluding race, age, income). The college experiences and events occur in typical settings such as classrooms, library, laboratories and athletic facilities. Experiences also are inclusive of other opportunities such as contact with faculty, participation in clubs/organizations or chances to develop writing skills.

The major contribution to student development research and a central focus of this model is the attention towards student effort. Pace (1979) contends that "All learning and development requires an investment of time and effort by the student. What students can gain from the variety of events depends on the amount, scope, and quality of their engagement" (p. 127). Therefore, if students make a concerted effort to use facilities or engage in college experiences, it will increase their opportunity for growth and development in college. Pace $(1979,1984)$ also identifies the environment as a key variable citing the expectations and emphasis of an institution (academic- 
scholarly, esthetic-expressive, critical-evaluative and vocational) as important in development. Within the environment, the nature of relationships between peers, faculty and administrative offices contributes to the obtainment of college outcomes.

As students exit the institution, Pace posits that their subsequent development can be assessed by comparing the criterion measures (knowledge, critical thinking, interests, values, personal traits, etc.) from when they began college to their time of exit. Other indicators of development and college impress include self ratings, attitudes toward the college, evidence from alumni surveys and commitment to continued learning. Most significantly, the students' quality of effort (measured by commitment, engagement and investment of time in their collegiate environment) is again a principal factor in their consequential development.

Pace's research became framework for two instruments: the College Student Experiences Questionnaire (CSEQ) and later the College Student Expectations Questionnaire (CSXQ) (see Appendix A) which will be used for the purposes of this study. The second edition of the College Student Expectations Questionnaire (Pace \& Kuh, 1999) was derived from the fourth edition of the College Student Experiences Questionnaire (Pace \& Kuh, 1998). The CSXQ measures students' expectations for their first year of college and how they plan to spend their time in educationally purposeful activities. The CSXQ activities are measured in eleven categories: Library and Information Technology, Interactions with Faculty Members, Course Learning Activities, Writing Experiences, Campus Programs and Facilities, Clubs and Organizations, Student Acquaintances, Scientific and Quantitative Experiences, Topics of Conversation, Information in Conversations and Amount of Reading and Writing (Miller, Bender, \& Schuh, 2005). 


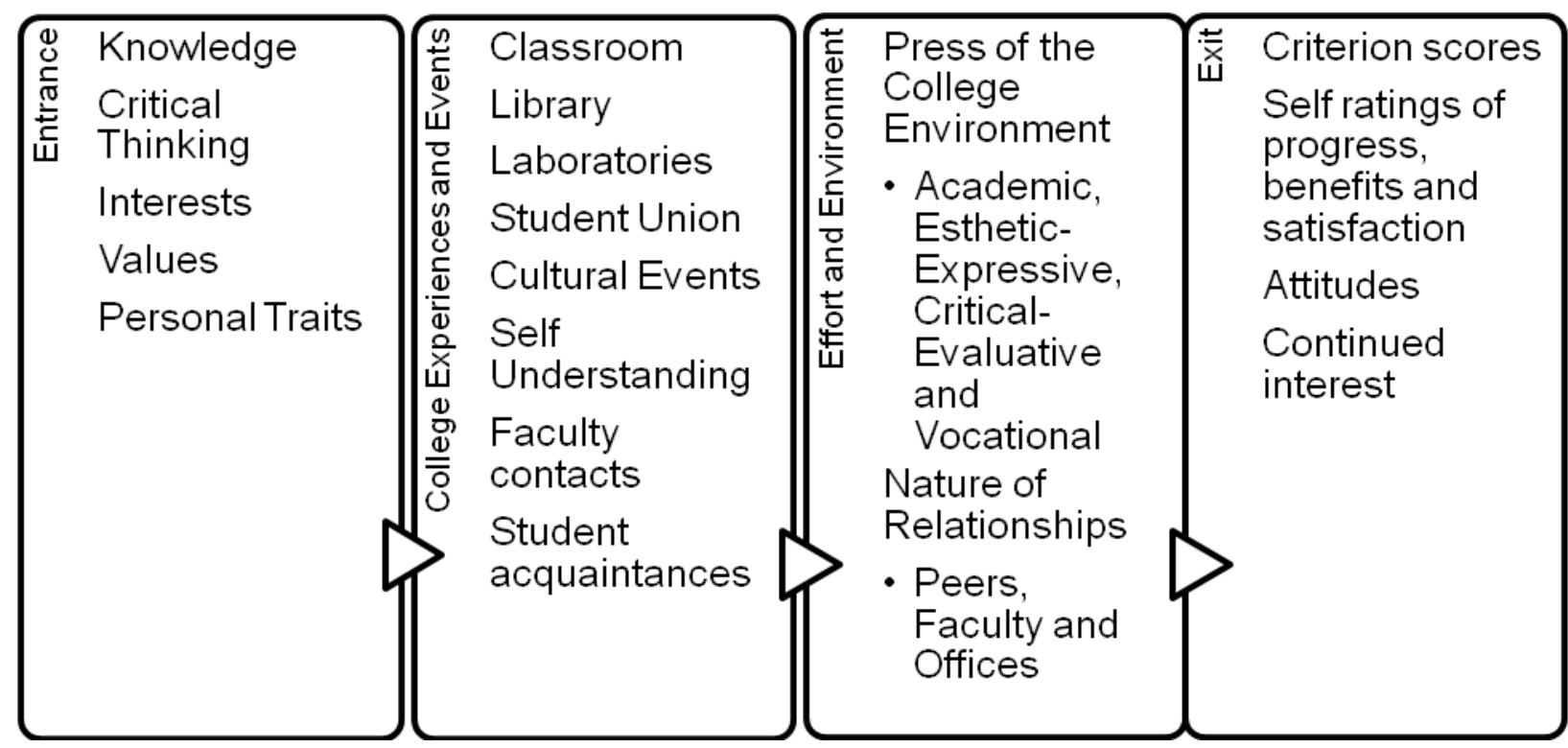

Figure 2. Path for a Student Development and College Impress Model. Adopted from "Measuring the Outcomes of College: Fifty Years of Findings and Recommendations for the Future" by C. Robert.Pace, 1979.

Tinto's longitudinal model of departure. Vincent Tinto is one of the most widely known and well researched theorists in the area of college student attrition. Derived from the Van Gennep's (1960) Rites of Passage and Durkheim's Theory of Suicide (1951), Tinto’s college impact model (1993) explains the longitudinal process by which students decide to withdraw from an institution with consideration to interactions amongst members of the college community and external environments. Connection to Van Gennep's former work is evident as Tinto's model explains the impact of family background, transition and integration into new college communities (academic and social). Positive experiences in college can strengthen commitments to persist whereas negative experiences may lead to lessened commitment and ultimately departure. Analyzing Durkheim's (1951) study of suicide, Tinto was able to draw a correlation as students similarly withdraw voluntarily from higher education when they are unable to become incorporated as members of the college environment.

According to the model, students enter higher education institutions with pre-entry attributes inclusive of: family background, skills and abilities and prior schooling. These pre- 
entry characteristics help students to formulate their intentions, goals and institutional commitments. External commitments help establish the circumstances for their future student experiences. Tinto's model takes into account the external community and its impact on student decisions to persist or depart. For example, many community college students who are typically commuter and/or working students have to contend with family and employment simultaneously as they navigate their way through the college community.

Tinto describes the Institutional Experiences of students from two major systems, academic and social:

The academic, concerns itself almost entirely with the formal education of students. Its activities center around the staff whose primary responsibility is the education of students. The latter, the social system of the college, centers around the daily life and personal needs of the various members of the institution, especially the students. (Tinto, 1993, p. 106)

Positive or negative experiences in either of these systems may lead to lessened integration (academic and/or social) and affect a student's decision to withdraw.

Integration is the extent to which the individuals shares the normative attitudes and values of peers and faculty in the institution and abides by the formal and informal structural requirements for membership in that community or in subgroups of it.

(Pascarella \& Terenzini, 2005, p.54)

Referring back to Van Gennep's (1960) Rites of Passage, the inability of students to become incorporated into the college environment will cause students to reevaluate their goals and commitments. The outcome rests upon the decision of students to either persist or to withdraw themselves from the college community. 
As an interactive college impact model, Tinto's work provides guidance as to how expectations and experiences will directly affect student decision-making. It reveals how the external community and systems of college (academic and social) are interconnected and continually interact with each other within formal/informal settings. Dissatisfying experiences and ultimate lack of integration in one system may lead to withdrawal. On the other hand, Tinto concludes that positive interactions, support from external communities, involvement and a connection between student and institutional goals can strengthen decisions towards persistence.

Despite the widespread recognition and usage of Tinto's model, criticisms centers on the exclusion of the experiences of ethnic minorities and nontraditional populations. Researchers suggested that Tinto's model relied on the experiences of primarily traditional age students; therefore, it excluded the non-traditional age, commuter student that is highly represented in the community college population (Pascarella \& Terenzini, 2005; Tierney, 1992). Subsequently, additional research of this student population has resulted in the identification of other additional factors pertaining to student departure such as parental involvement, finances, and peer support (Cabrera, Castaneda, Nora, \& Hengler, 1992). Later research in the 1990's also demonstrated the applicability of Tinto's model to community college and minority populations (Halpin, 1990; Bers \& Smith, 1991; Attinasi \& Nora, 1992; Cabrera, Castaneda, Nora, \& Hengler, 1992; Nora, Attinasi, \& Matonak, 1996). Future revisions of Tinto’s model by Braxton, Hirschy and McClendon (2004) and Bean and Metzner (1985) provided more conclusions on the impact of psychological and environmental factors on persistence.

Other student departure theories. As a model applicable to the community college population, Bean and Metzner (1985) explain the attrition of nontraditional college students inclusive of students older than 25, working and commuter students. Seven variables form the 
basis of withdrawal for nontraditional students: background and defining variables (age, enrollment status, residence, educational goals, high school performance, ethnicity and gender), academic variables (study habits, academic advising, absenteeism, major certainty and course availability), academic outcomes and GPA, environmental variables (finances, hours of employment, outside encouragement, family responsibilities and opportunity to transfer), social integration variables, psychological variables, and intent to leave. The environmental variables have the most influence over academic and social integration variables. Academic variables have a direct effect on academic outcome (grade point average).

All variables affect a student's intent to leave and subsequently drop out from college; however, the Bean and Metzner (1985) Model of Nontraditional Student Attrition introduces psychological outcomes in which all variables have a strong direct effect. Psychological outcomes such as utility, satisfaction, goal commitment and stress are the best predictors of a student's intent to leave college and can compensate for low academic performance (Johnson, 1991; Stahl \& Pavel, 1992). The model indentifies the direct influence of academic variables on GPA and the intent to leave as the two strongest predictors of persistence (Stahl \& Pavel, 1992).

Braxton, Sullivan and Johnson (1997) assessed Tinto's model by conducting an empirical test focusing on the degree of support for the 13 original primary propositions of Tinto's original model through single institutional studies. The results only supported five propositions and did not find strong support for academic integration as a consistent model of persistence. The researchers also identified that there was a lack of explanation on the element of social integration. Liu (2002) also contends that Tinto lacked clear operational definitions for the variables of his model. 
Berger and Braxton (1998) proposed investigating the campus organizational environment (organizational characteristics) and its impact on student persistence as elaborating on the social integration aspect of Tinto's theory. Organizational attributes include:

- Institutional Communication-how well informed are students about academic rules, social rules, course requirements and graduation requirements

- Fairness in Policy-extent to which students believe the following are done fairly at the university: enforcement of academic rules, enforcement of social rules, grading, and awarding scholarships

- Participating in Decision Making-how much say a student has in making decisions regarding: kinds of course assignments, amount of course assignments, making social rules, and making academic rules

More variables regarding pre-entry characteristics were also included such as income, high school grade point average, gender, race and political view. Their findings concluded that all three organizational attributes were predictors of social integration and were indirect effects on student persistence.

In developing a Theory of Student Departure in Commuter Colleges and Universities, Braxton, Hirschy and McClendon (2004) explains that "to untangle student departure in this institutional setting requires use of constructs derived from various theoretical orientations: economic, organizational, psychological, and sociological” (p. 35). Using a multidisciplinary approach, the theory posits that student entry characteristics, external environment and internal campus environment directly influence institutional commitment and persistence. Student entry characteristics include motivation, control issues, self-efficacy, empathy, affiliation needs, parental education and anticipatory socialization which affect initial institutional commitment 
and persistence. Initial institutional commitment is affected by both external environment and internal campus environment which both affects subsequent institutional commitment. The external environment consisted of variables that affect students at the community colleges such as: finances, support, work, family and community. The internal campus environment is categorized by two areas: academic communities and institutional environment. In the absence of prevalent and distinct social structures of commuter institutions, academic communities consisting of establishment of learning communities and active learning in the classroom environment becomes an even more important factor describing the internal campus environment that impacts subsequent commitment to the institution and ultimately student departure. Institutional environment is characterized by costs, institutional integrity and institutional commitment to student welfare.

Thus, multidisciplinary models by Bean and Metzner (1985) and Braxton, Hirschy and McClendon (2004) defined and clarified the academic and environmental variables of Tinto's theory and described factors that influence the departure decisions of the community college population. Both models also placed less emphasis on the social integration variable than Tinto supported in his earlier theory. As Tinto's model was primarily based on the traditional aged, residential university student, improvements to the original models identified variables attributable to the commuter and nontraditional student. Although Braxton, Hirschy and McClendon did not include race and gender as background variables like Bean and Metzner, both models discussed the implications of attrition on the subgroups of ethnic minorities and women who are reflected largely in the nontraditional age and community college student population. 


\section{Community College Student Expectations}

In general, students enroll in community colleges primarily for reasons related to employment, career development, degree completion and/or as a springboard to transfer to a four-year institution. Students also use the community college to complete general education requirements, enroll in difficult course before transfer, save money, decide on major and complete prerequisites for upper level courses or competitive majors (Cejda \& Kaylor, 2001). In a troubled economy the community college serves as a beacon for citizens pursuing financial stability and upward mobility in society through education (Laanan, 2003; Cox, 2009). The institution serves as a refuge for those who are employed to stay current in their skills and increase their marketability and competitiveness in the workforce. It also provides opportunity to seek out careers in demand for those who are unemployed, financially challenged, and career switchers. Students see the affordability of community colleges for training in specific skills which will lead to immediate employment, whereas, other students see the community college as an opportunity to develop skills which will assist them in advancing in a professional career (Horn \& Griffith, 2006). In 2003-2004, 47\% of community college students reported seeking job skills as a reason to attend college in the National Council for Education Statistics Study (Provasnik \& Planty, 2008). If there is a perceived lack of gains in students' employability and obtainment of job skills from attendance in community college, then the sacrifice of money and time is reconsidered which can lead to attrition (particularly in non-traditional students) (Monroe, 2006).

Current longitudinal studies of graduating seniors and currently enrolled community college students have revealed that students enter with the expectation of completing a degree. Provasnik and Planty (2008) classified students as "more committed" to degree attainment when 
they were enrolled in a formal degree program, enrolled at least part-time and reported that they enrolled in community college to transfer or complete and associates or certificate program. They concluded that one third of the 2004 high school seniors who entered college with the intention of just completing an associate's degree raised their expectations to the pursuit of a bachelor's degree. Monroe (2006) also identified a similar pattern of students who became motivated to continue their education beyond the associate's degree (although it was not their original intention). Therefore, the community college as transition point from high school or as a stepping stone to the university for students is still currently apart of the historical mission of these institutions.

By looking at the enrollment patterns and degree selection of students, one can also make an inference about the types of skills and careers that students expect to enter. Maxwell, et al. (2003) in their study of course taking pattern of students in the Los Angeles Community College District noticed that most first time students are not clustered or concentrated in any area of the curriculum (including introductory courses). Community college students may have to begin with remedial courses and then some occupational students are not exposed to as many introductory courses as those pursing the transfer track degrees. However, for those students who are able to eventually meet the requirements of a program of study, the U.S. Department of Education reports that most of the professional associates degrees conferred are in Healthcare and Business with the majority of degrees conferred in liberal arts and sciences, general studies and humanities (Provasnik \& Planty, 2008). All of these fields of study have options for transfer to the university level for those planning to continue their degree aspirations to the baccalaureate. 
Obviously, community college students expect to be able to pursue their studies at a lower financial cost than the university. Both groups of students designated in the transfer track degrees (Associate of Arts or Science) and occupational track degrees (Associate of Applied Arts or Applied Science) have ambitions of improving vocational skills and transfer ambitions. However, their attendance in community colleges allows them to complete general education courses at a savings leaving most of the major courses at university. Community college students tend to expect with the reduced costs the smaller classroom environments, positive interactions with faculty and advisors and quality service to achieve their goals.

\section{Essential College Outcomes}

In recent history, the American Association of Colleges and Universities (AAC\&U) has made considerable contributions to the literature regarding college outcomes important in the twenty-first century from the perspective of students, employers and leaders in the higher education profession. Beginning with Greater Expectations: A New Vision for Learning as a Nation Goes to College, this national panel report initiated a six year initiative from AAC\&U which focused on identifying relevant outcomes for the twenty-first century important for not only educated college graduates in the workforce but also citizens of the global community. The national panel proposed that regardless of academic major and career selection that all students should be empowered to develop into intentional learners that possesses a wide range of skills. Students are also expected to draw upon a large knowledge base to make decisions and adapt to different college, work and community environments (Association of American Colleges and Universities, 2002). AAC\&U's statement entitled The Learning All Students Need for the $21^{\text {st }}$ Century outlines college outcomes that support the development of the intential learner. 
Table 1

The AAC\&U LEAP Initiative's Essential Learning Outcomes (2002)

\begin{tabular}{|c|c|c|}
\hline Essential Learning Outcomes & Description/Outcomes Achievement & Demonstration \\
\hline $\begin{array}{l}\text { Knowledge of Human Cultures and the Physical } \\
\text { and Natural World }\end{array}$ & $\begin{array}{l}\text { Through study in the sciences and mathematics, } \\
\text { social sciences, humanities, histories, languages, } \\
\text { and the arts }\end{array}$ & $\begin{array}{l}\text { Focused by engagement with big } \\
\text { questions, both contemporary and } \\
\text { enduring }\end{array}$ \\
\hline Intellectual and Practical Skills & $\begin{array}{ll}\text { - } & \text { Inquiry and analysis } \\
\text { - } & \text { Critical and creative thinking } \\
\text { - } & \text { Written and oral communication } \\
\text { - } & \text { Quantitative literacy } \\
\text { - } & \text { Information literacy } \\
\text { - } & \text { Teamwork and problem solving }\end{array}$ & $\begin{array}{l}\text { Practiced extensively, across the } \\
\text { curriculum, in the context of } \\
\text { progressively more challenging } \\
\text { problems, projects, and standards of } \\
\text { performance }\end{array}$ \\
\hline Personal and Social Responsibility & $\begin{array}{l}\text { - Civic knowledge and engagement- } \\
\text { - } \text { local and global } \\
\text { Intercultural knowledge and } \\
\text { competence } \\
\text { - Ethical reasoning and action } \\
\text { - Foundations and skills for lifelong } \\
\text { learning }\end{array}$ & $\begin{array}{l}\text { Anchored through active involvement } \\
\text { with diverse communities and real- } \\
\text { world challenges }\end{array}$ \\
\hline Integrative Learning & $\begin{array}{l}\text { Synthesis and advanced accomplishment across } \\
\text { general and specialized studies }\end{array}$ & $\begin{array}{l}\text { Demonstrated through the application } \\
\text { of knowledge, skills, and } \\
\text { responsibilities to new settings and } \\
\text { complex problems }\end{array}$ \\
\hline
\end{tabular}

As a result, the Liberal Education and America's Promise (LEAP) initiative of AAC\&U was created which promotes the value of liberal education for all students. The initiative recommends the preparation of students to develop essential learning outcomes detailed by their College Learning for the New Global Century Report (AAC\&U, 2007). The responsibility of student achivement of essential learning outcomes is not delegated to one academic department or discpline. AAC\&U (2007) calls for a shared responsibility in providing students with 
opportunities to be introduced to the liberal arts and educating students about its utility in the workforce and community. Understanding that narrow technical concentration in a career field is limiting to students' future potential, the LEAP initative champions the outcomes provided in Table 1 to help students develop from secondary instruction through the college experience.

Subsequently, colleges are faced with the task of aligning outcomes with curricular and co-curricular experiences. The areas of knowledge and intellectual skills identified as common learning outcomes by a 2009 study of 433 Chief Academic Officers of the Association of American Colleges and Universities member institutions are represented in Table 2 (Hart Research Associates, 2009).

Table 2

Areas of Knowledge and Intellectual Skills/Ability Identified by AAC\&U Member Institutions as Common Learning Goals

\begin{tabular}{llll}
\hline Areas of Knowledge & \% of Member Institutions & Intellectual Skills/Ability & \% of Member Institutions \\
& Reported as Common Learning & & Reported as Common Learning \\
& Goal & & 77 \\
\hline Humanities & 72 & Writing Skills & 74 \\
Science & 71 & Critical Thinking & 71 \\
Social Science & 70 & Quantitative Reasoning & 69 \\
Global/World Cultures & 68 & Oral Communication & 62 \\
Mathematics & 68 & Intercultural Skills & 59 \\
Diversity in the U.S. & 57 & Information Literacy & 59 \\
Technology & 48 & Ethical Reasoning & 53 \\
U.S. History & 39 & Civic Engagement & 52 \\
Languages & 33 & Application of Learning & 51 \\
Sustainability & 18 & Research Skills & 49 \\
& & Integration of Learning & \\
\hline
\end{tabular}

Writing skills. Most colleges and univerisites have a college composition or first-year writing requirement as a general education course offered by an English department. In 
community colleges, along with the offerings of developmental English and English and Second Language instruction, the writing offerings for students (for academic credit) are heavily weighted towards composition courses and approximately half of all first year writing courses are offered at the community college (Hennessey, 2005; Taylor, 2009). Breaking disciplinary boundaries, a shared responsibility for the development of students' written communication skills has grown particularly with Writing Across the Curriculum (WAC) and Writing in the Disciplines (WID) programs. Writing provides the means in which to measure learning in multiple disciplines as students "use this skill in all aspects of the university experience such as taking notes, developing essays, and responding to examinations-each unequivocally related to college success" (Plata, 2008, p. 366). However, the criticisms of Writing Across the Curriculum programs in community colleges are that they focus more on the structure and lowerorder writing skills rather than the higher order critical and analytical thinking skills (Hennessey, 2005).

Critical thinking. Although there is not a universal agreed upon definition of critical thinking in higher education literature, many definitions refer to the utilization of skills to achieve a required action based on evidence and consideration of various entities. The Foundation for Critical Thinking describes it as:

the intellectually disciplined process of actively and skillfully conceptualizing, applying, analyzing, synthesizing, and/or evaluating information gathered from, or generated by, observation, experience, reflection, reasoning, or communication, as a guide to belief and action. In its exemplary form, it is based on universal intellectual values that transcend subject matter divisions: clarity, accuracy, precision, consistency, relevance, sound evidence, good reasons, depth, breadth, and fairness. (Scriven \& Paul, 2009) 
They also describe a well cultivated critical thinker as a person who:

- raises vital questions and problems, formulating them clearly and precisely;

- gathers and assesses relevant information, using abstract ideas to interpret it effectively comes to well-reasoned conclusions and solutions, testing them against relevant criteria and standards;

- thinks open-mindedly within alternative systems of thought, recognizing and assessing, as need be, their assumptions, implications, and practical consequences; and

- communicates effectively with others in figuring out solutions to complex problems (Paul \& Elder, 2009).

Various skills and abilities are exercised in exercising critical thinking skills and not identified as being developed in only specific academic disciplines. Along with discipline specific critical thinking abilities, Monahan (2003) identifies the academic, professional, public and private domains of critical thinking which are also valuable for educated individuals. Therefore, critical thinking must be transferrable not only throughout the curriculum but also in professional and daily lives of college graduates.

Like other college outcomes, critical thinking is developed in various courses in the curriculum as well as co-curricular experiences. It is frequently mentioned in community college missions, as a college outcome of general education and in program specific goals; however, the concern has been whether this skill is being taught properly in the classroom and whether community college students demonstrate weak critical thinking skills beyond high school (Pierce, 2005). Faculty are generally eager to assist in the development of these skills but have significant barriers in obtaining this objective including: student resistance to the pedagogical techniques as well as lack of preparation to teach critical thinking (Brookfield, 2005; Halx \& 
Reybold, 2005). It also brings attention to possible social inequality in higher education where students at the more elite colleges or four-year institutions have more experiences to develop critical thinking skills and faculty are provided with the additional resources (professional development/training) to teach it effectively (Tsui, 2003). Although community college students through their professional and personal lives may have experienced various situations in applying critical thinking, Bers (2005) contends that assessing critical thinking in community colleges in particular is challenging because there are many students who do not persist to a degree and frequently depart from institutions. Another challenge identified by Brookfield (2005) in his ten year qualitative study of community college students is the "lack of affect, emotion, spirituality, or holistic modes of being and knowing" as well as the Eurocentric and predominately male literature, research and theoretical base of critical thinking directed towards a more diverse student population (p. 56).

Critical thinking is not isolated in one area of the curriculum whereas a combination of both discipline and pedagogy appear to affect students' gains in critical thinking skills. In solving problems, a multi-disciplinary approach and various strategies may be employed. Using data from the California Critical Thinking Disposition Inventory (CCTDI), Lampert (2007) found that students in an arts curriculum (studio art, design and art education) had greater gains in critical thinking dispositions than non-arts students. The approach of arts faculty with engagement activities, creative thinking and the classroom climate was attributable to differences in both groups.

Critical thinking appears to be influenced by either course content or instructional technique; however, both are very important influences. One of the most influential research on this topic included a national study using data from the Cooperative Institutional Research 
Program (CIRP) 1989 Follow Up Survey. Tsui (1999) found that completing commonly offered college courses as well as instructional variables (with the exclusion of taking a multiple choice test) had a positive association with students' self-reported development of critical thinking skills. Instructional variables included: having a paper critiqued, taking an essay exam, working on a group project, conducting independent research, and giving a class presentation. Courses variables selected were courses emphasizing: writing, math, science, history and foreign language as well as interdisciplinary, women's studies, ethnic studies, reading/study skills, remedial and honors courses.

Quantitative \& scientific reasoning. The associated courses that are connected to the outcomes of quantitative and scientific reasoning or literacy are typically the most intimidating to students and particularly community college students (Bluestone, 2007). Ramaley \& Haggett (2005) identifies several reasons that students avoid mathematics and science from its perception of being "cold" and analytical or being intimidated by the mathematical reasoning skills needed to understand scientific concepts.

Introductory mathematics courses inclusive of pre-algebra, algebra and pre-calculus would fulfill a mathematics requirement in the curriculum; however, these are the same types of courses that are typically offered on a high school level or an entry requirement for college admission. A quantitative literacy requirement transends basic mathematical processes to being able to make connections between disciplines and using critical thinking skills and problem solving abilities. The goal of teaching quantitative literacy skills is for students to use it (applied mathematics) throughout their academic, profesional and personal lives. Jordon \& Haynes (2003) model of quantitative literacy entails three component parts that works together: (1) foundational statistical and mathematical skills, (2) quantitative reasoning skills, and (3) positive, 
confident attitudes and beliefs about mathematics and quantitative reasoning. Examples of college level quantitative literacy courses include: Counting People, Economics and the Environment, Health Economics, Introduction to Energy Sources, Introduction to Population Studies, Language and Formal Reasoning, Limnology: Freshwater Ecology, Maps, Visualization, and Geographical Reasoning, Practical Physics: How Things Work and Quantifying Judgments of Human Behavior (Steen, 2004). Instructors within general education disciplines have also updated their pedagogical practices to increase students' quantitative literacy within disciplines such as Environmental Biology, Introduction to Sociology and First Year Seminar or offering specialized topics such as social justice, current news or pop culture (Hastings, Arzberger, Collins, Ives, Johnson, \& Palmer, 2005; Meyer \& Dwyer, 2005/2006; Dietz, 2006; Hill, 2007; Pinter, 2007)

As an important component of liberal education, the study of scientific literacy also contributes to the development of transferable skills needed for an educated workforce (teamwork, problemsolving, leadership, communication and critical thinking). Like mathematics, science remains a common requirement of the undergraduate curriculum with requirements such as in the natural sciences (biology) and/or physical sciences (physics, chemistry, etc.). Students may need one or two courses to meet the a general education requirement and exposure to more sciences courses would depend on the requirements of the academic major (Bluestone, 2007). However, like mathematics, it is also considered by students as an unattractive option particularly for non-science majors (Ramaley \& Haggett, 2005).

Beyond the basic introductory science courses, the concept of scientific literacy, like other similar approaches (i.e. Writing Across the Curriculum), integrates with multiple discplines including social sciences and humanities to make science education more relevant and practical 
to students as citizens. Connecting with real-world issues of interest increases students knowledge of the socio-cultural connection science and increases their engagement (Ramaley \& Haggett, 2005; Hammer \& Dusek, 2006). Various course offerings or assignments centers around multidisciplinary topics including societal issues such as global warming, stem cell research and genetic engineering.

As methods to foster learning, some science faculty have divested from the traditional lecture and lab pedagogy (cookbook approach) to more active learning and engagement experiences in real world problems (George, 2010). Traditional general education courses, such as introductory psychology, have also adopted active learning curricular approaches within the discpline to improve scientific literacy skills (Perlman \& McCann, 1993). Divesting from the idea that all knowledge comes from the instructor, the literature suggests that assigments which validate students as knowers and capable of scientific inquiry through writings, argumentation, undergraduate research, learning communities and cases studies provides students a hands-on experience and validation of their abilities in the field of science (Udodvic, Morris, Dickman, Postlethwait, \& Wetherwax, 2002; Kelly \& Bazerman, 2003; Bluestone, 2007; George, 2010). These curricular approaches are particularly important to fostering more engagement of minorities and women in scientific study.

Oral communication. In multiple courses throughout the curriclum, students may be asked to participate in multiple ways of verbal expression through oral presentations, participation in class discussions, and communicating to students from different cultures. The inability to accomplish such tasks throughout a students' undergraduate study may impact academic and professional success after graduation. Therefore, the development of students' oral communication skills remains another expected college outcome of graduates although there 
does not appear to be much allowance in the curriculum to accommodate for multiple courses. Engleberg, Emanuel, Van Horn and Bodary (2008) found that communication still remains a strong fixture in most community college general education programs as many transfer students may take their one and only communication course at the community college. They found that $83 \%$ of the community colleges in their study of National Communication Association members required at least one course of communication. Most colleges only allow for one course as a requirement (40.4\%) with the predominant course offered as public speaking followed by fundamentals, interpersonal communication, small group, business, and intercultural. Therefore, like Writing Across the Curriculum, oral communication competencies are now being taught and assessed in a wide range of general education courses (Dunbar, Brooks, \& Kubicka-Miller, 2006).

Intercultural skills. In the new millenium, there has been an effort to increase the inclusion of international education and/or global education in university mission statements; however, there remains some difficulty in aligning curriculum and programs to achieve the goals (Jergens \& Robins-O'Connell, 2008). With multiple missions, international education is found to not be a central focus in the curriculum or programs of many community colleges (Green \& Siaya, 2005). As faculty are heavily involved in developmental education and introductory studies in the disciplines, the goals to increase international literacy are considered peripheral efforts (Latiner Raby \& Valeau, 2007).

The development of cultural literacy can be obtained through learning experiences inside and outside of the college classroom (inclusive of study abroad programs). In a general education distribution curriculum, a variety of disciplines may contribute to this important college outcome. Sterns (2004) acknowledges areas such as sociology, psychology, history and 
English as common contributors to cultural studies course offerings; however, he recommends connections with disciplines such as sciences and humanities for a more cultural analysis. Cultural studies courses can also be provided through interdisciplinary options within the general education curriculum as a combination of various discplines. However, instead of using these courses to be descriptive, Sterns (2004) contends they should build skills in cultural analysis by providing students with the opportunity to use critical thinking skills in understand the relationships and connection between people and social institutions.

Information literacy. The use of information literacy skills by college students within higher education will have an impact on not only their academic success in general education but discpline related courses. A move to new pedagogies (student centered, active learning, resource based learning), the widespead use of electronic information to disseminate information (journals, books, syllabi, etc.), the ability to conduct successful research, and understand the societal aspects of technology will also have an effect on students' acclimation to the college environment (Sellen, 2002; Lupton, 2008). Although there are various definitions of this term, the Association of College and Research Libraries (2000) describes it as "a set of abilities requiring individuals to 'recognize when information is needed and have the ability to locate, evaluate, and use effectively the needed information"” (p. 2). This definition goes beyond understanding computer technology (computer literacy), the areas and functions of a university library or basic electronic communication skills. The Association of College and Research Libraries (2000) established Information Literacy Competency Standards for Higher Education which includes the ability to:

- Determine the extent of information needed

- Access the needed information effectively and efficiently 
- Evaluate information and its sources critically

- Incorporate selected information into one's knowledge base

- Use information effectively to accomplish a specific purpose

- Understand the economic, legal, and social issues surrounding the use of information, and access and use information ethically and legally (p.3)

Gratch-Lindauer (2008) compared the relationships between the information literacy items on the National Student Engagement Survey (NSSE) that related to the ACRL standards and the items pertaining to practical competence and general education scales finding positive relationships with engagement. Information literacy is also connected to the development of other important outcomes and skills such as written communication, critical thinking, problem solving, research, critical reading and lifelong learning (Mackey \& Jacobson, 2004; Lupton, 2008).

Traditionally, college librarians have been the leaders of efforts to develop information literacy skills of college students and train college faculty to integrate information literacy in their instruction and pedagogy (Association of College and Research Libraries, 2000; Sellen, 2002). Although some colleges and universities offer courses centered on information literacy, it tends to have very low enrollment without it being a requirement for degree completion. With more demand from future employers and accrediting bodies to include information literacy as a college outcome of graduates, current practice tends to integrate instruction throughout the curriculum using freshman seminar, general education and discipline specific courses to introduce and develop students' skills using supplemental instruction and the resources of college librarians for both students and faculty (Sellen, 2002). Efforts to strengthen students' information literacy skills also include connecting information literacy instruction through the 
general education curriculum providing coherence as students move from lower to upper level courses and allowing students to reinforce and develop skills from freshman to senior year (Rockman, 2002).

Ethical reasoning. The development of moral judgment of students can occur in various contexts within a higher education institution through the academic disciplines and through experiences within the campus community. In the general education core, ethics courses are offered at many universities and statements about values and ethics are found in many university missions or general education goals (Stephan, 2003; Glanzer, Ream, Villarreal, \& Davis, 2004). Specific ethics courses are offered as an option within a distribution (humanities/fine arts) or as a course requirement for professional programs (particularly healthcare, business and engineering related fields).

Due to the emphasis on career and technical education, values education has been viewed in the literature as marginalized. Instead of offering specific courses as a graduation requirement, an alternative is to incorporate ethics within the discipline. Various curriculuar approaches such as case studies, class discussion, service learning and reflective thinking have also been used by instructor as methods to develop moral judgment of college students (Stephan, 2003). King and Mayhew (2002) contends that content and curriculular approaches are useful in measuring the impact of moral judgment development of students as opposed to academic disciplines. However, significant barriers to implementing values education in the collegiate environment includes a reluctance from faculty, indecisiveness of what values are important to teach, fragmentation of the discplines and trends towards being objective/value free (Glanzer, Ream, Villarreal, \& Davis, 2004; Serotkin, 2005/2006). 
The collegiate environmnent and co-curricular experiences are an important factor where students experience opportunities for growth in moral reasoning, judgment and behavior. The exchange of ideas through campus activities, developing friendships, student leadership, participation in fraternities/sororities and competitive activities (athletics, academic teams and debate teams) are collegiate factors that can affect moral development outside of the traditional classroom (King \& Mayhew, 2002). Other areas where values education is reinforced within the college enviroment centers on the institutional policies for students such as honor codes, student rights and responsibilites, residence hall policies and judicial affairs.

Civic engagement. Civic engagement or civic education appear to be less valued by students as a college outcome than others that are considered to be more connected with employablity (McClure, Rao, \& Lester, 1999; Hart Research Associates, 2004; Hart Research Associates, 2005). Significant barriers have been identified which prevents a robust civic education within the general education programs of colleges and universities including the workforce training culture and the consumerism attitudes of students (Higginbottom \& Romano, 2006). Colleges also face challenges in articulating the importance of civic engagement and the ability of faculty to make the connection in the academic experience. This is an even more complicated task for community colleges as they educate larger populations of first generation and underprepared college students needing developmental education. However, there is a void in research and literature on civic engagement and social justice in community colleges (Prentice, 2007).

Opportunities in developing civic engagement as a college outcome in higher education have found success with experiential and active learning pedagogies, particularly with service learning programs, learning communities and interdisciplinary studies (Hodge, Lewis, Kramer, 
\& Hughes, 2001; Spiezio, Baker, \& Boland, 2005; Higginbottom \& Romano, 2006). Considering the setting of community colleges, they are in a key position to consider models that would connect to local issues (on and off campus) that would drive student/faculty participation in engagement activities (Ostrander, 2003). Pedagogical practices such as service learning affects the value that students place on citizenship as well as related student learning outcomes (Hodge, Lewis, Kramer, \& Hughes, 2001; Spiezio, Baker, \& Boland, 2005). These models require that additional work for faculty and additional resources from adminstrators are necessary including training, release time, and funding. Due to the demand of other priorties within the community college (developmental education, workforce training, etc.), interested faculty may not have the time nor resources to develop and sustain such efforts without adequate support.

\section{Community Colleges and General Education}

General education is not a new concept of the community college and has been a fixture in the curriculum since its beginnings. Using the liberal arts as the conduit to provide general education, the various subject areas of communication, arts and humanities, mathematics, natural sciences, and health/physical education has been a part the community college course offerings for decades (Schuyler, 1999). General education in community colleges can be described as the portion of the curriculum where students are provided with both knowledge of the liberal arts disciplines and skills in communication, critical thinking, scientific and quantitative reasoning, cultural literacy, and computer competency. The attainment of both knowledge and skills is important in the community college's preparation of students for future success as citizens and in the workforce.

An overwhelming number of community colleges use the distributional model to deliver general education (Schuyler, 1999; Zeszotarski, 1999). In her quantitative analysis of 
community college catalogs, Zeszotarski (1999) found that over $90 \%$ of universities and the majority of community colleges studied followed the distributional model over the core curriculum or the free elective system. This delivery method of general education allows students to choose courses from several categories of subject area electives has come under criticism and labeled as: cafeteria style, a smorgasbord, disjointed, disintegrated plain vanilla, disconnected, a shopping mall, and fragmented. It has also been described as a replication of the distribution requirements of the closest four-year university (Cohen \& Brawer, 2008). Although Path and Hammons (1999) found in their national study of Chief Academic Officers that many of these administrators would prefer a more student-centered approaches (as opposed to subject centered), they realized that the formidable barriers of initiating a new approach (including faculty resistance and transfer issues) made instituting reforms an insurmountable task. In a more recent study of Chief Academic Officers, Hart Research Associates (2009) found that the majority of their member institutions have increased general education as a priority for their institutions and are currently undergoing modification or assessment. With approximately $80 \%$ of member institutions utilizing a distribution model, new developments reveal that only $15 \%$ of those institutions use that model exclusively. Colleges have combined other approaches such as: common intellectual model, thematic required courses, upper-level requirements, core curriculum, and learning communities (Hart Research Associates, 2009).

Another theme of the literature in the late 1990's was the attention provided to the noticeable differences between general education in transfer and occupational oriented programs. Distributional models allow for more student choice in common subject categories such as: Social Sciences, Natural Sciences, and Humanities/Fine Arts. Therefore, those students pursuing Associate of Arts and Associate of Science degrees can select properly based on their transfer, 
occupational or personal interests. However, students in occupational degree programs such as the Associate in Applied Science degree typically have less choice and their general education program is pre-selected (Schuyler, 1999; Zeszotarski, 1999). As transfer students typically receive most of their general education at the community college and occupational students may not receive any further general education beyond the associates degree, an examination of general education in both areas of the community college curriculum is relevant.

\section{College Student General Education Experience}

There is a void in the literature that addresses the community college students' attitudes towards general education. However from recent studies, it appears that most college students value liberal and general education goals but the following factors affect their view of the curriculum or courses: (1) incoherence and a lack of connection to general education/personal goals of students, (2) perceived lack of value, (3) faculty and classroom experiences, and (4) a perceived barrier to academic major and career pursuits (Muffo, 2001; Hart Research Associates, 2004; Kleinke, 2005; Hart Research Associates, 2005; Harmes \& Miller, 2007). Students also have different opinions about general education advising but it is clear that there are needed improvements in ways to articulate the purpose of general education goals and curriculum to students more effectively.

Coherence/connection. Various studies indicate that many students are open and accepting to receiving a liberal education while they are in college, see the importance of related college outcomes, and understand the need for a broad exposure to various subjects; however, they perceive the curriculum to be incoherent and fail to see the connection between the curriculum and college outcomes (Hart Research Associates, 2004; Hart Research Associates, 2005; Harmes \& Miller, 2007). As a result, they are in most cases unable to articulate clearly the 
concepts of liberal education, general education or define common areas of the distribution requirements such as Humanities or Social Sciences (Dallinger \& Mann, 2000; Anderson, et al., 2007).

With the organization of broad courses within a distribution requirement that allow for multiple choices, the general education curriculum appears to college students as disjointed (Harmes \& Miller, 2007). Particularly without clear communication and advising processes to explain the purpose of general education requirements and to guide with course selection, the curriculum also appears to be lacking in focus to students. They see a disparity between the outcomes the college proposes are a result of the study of general education courses and the reality of their academic experiences. The biggest disconnection appears to be the inability to relate general education to students' personal goals.

What students value. There are two notable studies that reveal the college outcomes that students value most prominently. McLure, Rao, Srikanta and Lester (1999) used data from a national ACT College Outcomes Survey to compare responses relating to general education and personal growth of students at Historically Black Colleges and Universities (HBCU's) and nonHBCU's. Students at the Historically Black Colleges and Universities rated items higher in both areas. Table 3 indicates the shared areas of most importance of the HBCU and non-HBCU students. Both populations of students similarly value skills that will increase their competence as a learner, college student, and future graduate. They both did not value highly common areas of the general education programs including civic engagement (personal growth), scientific knowledge, and humanities (general education). 
Table 3

Shared Highest and Lowest Ratings of HBCU and Non-HBCU Students from the McClure, Rao, Srikanta and Lester 1999 Study

\begin{tabular}{lll}
\hline Shared Ratings & \multicolumn{1}{c}{ General Education Outcomes } & Personal Growth Outcomes \\
\hline Highest & Broaden my awareness of diversity among people, & Taking responsibility for my own \\
& their values and cultures & behavior \\
& Become a more independent and self-directed learner & Setting long-term or life goals \\
& Develop as a "whole person" & Increasing my intellectual curiosity \\
Lowest & Increase my knowledge of the earth and its physical & Preparing myself to participate \\
& and biological resources & effectively in the electoral process \\
& Appreciate great works of literature, philosophy and art & Actively participate in volunteer work
\end{tabular}

Most of the research studies that discuss student perceptions of curriculum are qualitative research studies consisting of focus groups and interviews to collect and organize students' responses. In 2004, Hart \& Associates conducted six focus groups sponsored by the American Association for Colleges and Universities (AAC\&U) with a group of rising high school seniors planning to go to a four-year university and a second group of juniors and seniors at public and private universities in Indiana, Oregon and Virginia. An additional two focus groups were conducted again in Wisconsin in 2005 with the same population format. Prior to their focus groups, students were asked to complete a survey to rank college outcomes derived from the Liberal Education and America's Promise (LEAP) campaign of AAC\&U. Again, these students also ranked higher in their top tier outcomes, the skills that would contribute to their growth as a student learner and career professional. The five outcomes for the 2004 and 2005 focus group participants are identified in Table 4. 
Table 4

Top Tier College Outcomes of Wisconsin (2005) and Indiana, Oregon \& Virginia (2004) Focus Group Participants

\begin{tabular}{ll}
\hline \multicolumn{1}{c}{ Indiana, Oregon \& Virginia (2004) Students } & \multicolumn{1}{c}{ Wisconsin ( 2005) Students } \\
\hline A sense of maturity and how to succeed on your own & A sense of maturity and how to succeed on your own \\
Time management skills & Tangible business skills, and a specific expertise \& \\
Strong work habits & knowledge in your field of focus \\
Self-discipline & Strong work habits \\
Teamwork skills, and the ability to get along with and & Teamwork skills, and the ability to get along with and \\
work with people different from yourself & work with people different from yourself \\
& Self-discipline \\
\end{tabular}

Similarly to the McClure, Rao, Srikanta and Lester (1999) study, students also ranked outcomes related to civics as the lowest as well as outcomes related again to humanities, science (Wisconsin study), culture and computer competency. However, the authors contend that this does not mean that students believe these outcomes are unimportant. They may not view the outcomes as directly linked to the college experience or curriculum. Students depending on their backgrounds may already feel competent in certain areas, particularly if they already are from diverse environments or have already been exposed through secondary school instruction.

College students value the practical focus, life skills, career applicable knowledge that general education programs can develop during their collegiate studies (Hart Research Associates, 2004; Hart Research Associates, 2005; Harmes \& Miller, 2007). Simmons (2005) found that even premedical students have a positive attitude towards liberal education. Despite being known as competitive students who are guarded in their course selection to receive the most impressive grades, they understood the value of the transferrable skills learned beyond study of the natural sciences. However, the literature also reveals serious disappointment and 
disconnect from students when those qualities of liberal education are not evident. Cox (2009) found that when the students' motives for career preparation and financial stability will not be realized, they begin to doubt whether college courses are worth the time, effort, and expense. In a 2005 focus group conducted on college freshman and sophomores at Utah State University, students found the following skills to be useful in their lives and academic experience: writing, communication, financial, interpersonal relations, cultural literacy, and environmental awareness. Students also reported that general education courses served as a transition from high school, impacted college success skills (study, reading and writing), and was helpful in the selection of a major and career (Kleinke, 2005). In an earlier study conducted at Virginia Tech, student focus groups discussed the disadvantages more than the advantages of their core curriculum; however, students appeared to have an interest in receiving more guidance in the selection of core courses that would be useful towards their personal goals (Muffo, 2001).

Faculty/classroom experience. An influential factor affecting students' perceptions of general education appear to be the attitudes of college faculty and their classroom experiences (Byrd Murphy, 2008). The impact of faculty engagement and buy-in is of great consequence as House (2006) identified four types of interaction with faculty that were positively related to satisfaction with general education courses: (1) the opportunity to work on research projects outside of class, (2) the opportunity to discuss coursework outside of class, (3) receiving advice about the educational program, and (4) receiving assistance with study skills.

The classroom experience also had a major influence on how students view general education. When faculty are unable to connect students' personal goals to general education goals, students' perceptions were impacted (Muffo, 2001). A common message by students in the related literature was that the general education courses were large, overcrowded and 
impersonal which affects their satisfaction (Kleinke, 2005; House, 2006). Ironically, they also report a lack of challenge and that courses were duplicative of the learning they received in secondary education or did not provide a comprehensive coverage of the subjects offered (Hart Research Associates, 2004; Harmes \& Miller, 2007; Miller \& Sundre, 2008).

When there is a mismatch between student expecations and the reality of their general education experience, students resort to approaches that result in their attempts to "beat the system." Cox (2009) describe students' strategies to either "make the grade" or "get it over" when they determine that their learning goals leading to career development are not being accomplished. Students who "make the grade" simply do whatever is necessary to receive the best grade; however their investment in learning and putting information to practical use in the future is compromised. Students "getting it over" will complete coursework with minimal effort just enough to pass the course. In her semester long study of students enrolled in a freshman composition course at a Southwest community college, Cox (2009) found that most students begin their studies with a desire to learn something significant in their courses but adopt the "make the grade" or "get it over" approach when they find that the material is not relevant. Even in a study amongst honor students (who often are provided with the most sound liberal education curriculum) Storrs (2008) found students who resorted to these same approaches categorizing them into four ideal types:

(1) "liberal scholars" embraced a liberal arts education, (2) "getting by" students, while academically successful, displayed limited curiosity and minimal academic effort; (3) "players" were future oriented and academically engaged primarily for the pursuit of grades and scholarships; and (4) "critical players" were critical of the emphasis on grades 
and felt pressured to conform to academically narrow specialties despite their desire to be more liberally educated. (Typology of Learners section, para.1)

\section{Summary}

In the last decade, there has been focused attention on the types of knowledge and skills that are needed in today's society in the workforce and as citizens and the role of colleges in providing learning experiences (Association of American Colleges and Universities, 2002; Jones, 2002; Hart Research Associates, 2009). However, there is a research void that addresses community college student expectations beyond typical vocational and transfer goals. The studies that assess students' value or perception of college outcomes are generally exclusive of community college student populations. Although, the literature is still helpful in understanding that students value many college outcomes as being very important once they are defined.

Unfortunately, college students report that college outcomes or general education goals espoused by the university are not communicated clearly or they do not see a connection in their academic experiences. As Pace $(1979,1984)$ suggests, this apparently can impact the quality of effort that a student exert towards learning. Students who choose to persist will cope by adapting methods to just "get by" or "make the grade" with minimal effort (Storrs \& Clott, 2008; Cox, 2009). Other students whose expectations are incongruent with the realities of their college experience may feel dissatisfaction with their academic integration in the college community and choose to depart as suggested by Tinto (1975, 1987, 1993), Bean and Metzner (1985) and Braxton, Hirschy and McClendon (2004).

General education is a major portion of a student's associate degree. The ability of students to complete those courses will impact their success in college. For many community college students, the general education that they receive at these institutions will be their only 
exposure to this curriculum. Therefore, as general education is the conduit in which many students are introduced to college outcomes, their learning experiences will impact their future experiences in major area disciplines, transfer universities as well as in the workforce. In the subject centered distribution requirement model (which most community colleges follow), a common theme identified in the literature is that there is an apparent restriction in the amount of courses allowed by academic departments in a general education distribution. For example, speech typically will have a one course requirement, whereas science, mathematics and writing will have a one or two course requirement. At the same time, communication, quantitative and scientific literacy are skills that students will need throughout the curriculum.

Therefore, the curricular approaches of expanding learning opportunities in the relevant college outcomes throughout disciplines, adding multidisciplinary studies, and providing active learning experiences are ways in which colleges are attempting to demonstrate the utilitarian side of liberal education. Significant challenges face community colleges as they attempt to change their culture to adapt new approaches to liberal learning; however, failure could have serious societal impact. As more students are choosing to attend community colleges are inclusive of atrisk student populations, the inability to provide a liberal education to these students is viewed as fostering social inequity (Tsui, 2003; Sacks, 2009). 


\section{Introduction}

\section{CHAPTER THREE}

\section{Research Design and Methods}

This study explored the expectations of first year community college students regarding general education goals. Using a commercially-developed survey instrument, the study investigated what essential learning outcomes students expected to be emphasized at a community college and how much effort students expected to apply toward learning activities.

This chapter will provide an explanation of the methodology used for this study including the following areas: research design, population and sample, instrumentation, data collection and procedures, data analysis, and limitations. In this study, data were collected from first-time community college students enrolled in a required Student Development course at a multicampus community college.

\section{Method: Quantitative Research Design}

A quantitative research design was appropriate to address the research questions since there was a commercially developed instrument to gather relevant information about students' perceptions. This instrument has been revised and further information about reliability and validity will be presented in this chapter.

Population and sample of participants. The site for this study was a public suburban multi-campus community college located in a large metropolitan area. Multi-campus Community College (MCC) (fictitious) is one of the largest community colleges in the United States with 46,619 students enrolled the previous Fall 2009 semester in credit courses. MCC has six campuses, two centers, and offers courses through distance learning. This institution was selected because it services a diverse student population and offers a variety of transfer and 
occupational degree programs. $\mathrm{MCC}$ is also the largest institution of higher education and the largest awarder of associate degrees/certificates in the state.

The study utilized a sample of first-time students (meaning first time at MCC) enrolled in a Student Development (SDV) course which is required for graduation. As community college students enter and exit at various points throughout the curriculum, it is very difficult to find courses with a high concentration of beginning students. SDV meets the community college system and college's requirement for the Personal Development goal of General Education. As a graduation requirement, this course was also selected because it captures a majority of students interested in the completion of a degree and/or certificate. Eight hundred and thirty six students were enrolled in the SDV courses selected for this study according to the college's computer enrollment management system accessed by the researcher.

With the revolving door of community colleges, courses within the general education curriculum run the risk of having not only first time students but continuing and returning students (after a leave of absence). Therefore, a sample of convenience was used for this study to capture the expectations of students within their first semester of enrollment at community college.

The specific SDV courses (College Success Skills and Orientation to Healthcare) and course sections chosen for this dissertation study were restricted to first-time college students. During the summer semester, the sections were identified from the college's online enrollment management system and verified by the coordinators of two student affairs programs for first year students. The sections were offered at five of the six campuses of MCC during the 16, 14 and $1^{\text {st }} 8$ week session of the Fall 2010 semester (see Table 5). The selected 26 sections of SDV courses were capped for a maximum enrollment of 938 students. Approval for the study 
and the use of participating SDV courses was provided by the Associate Vice President for Institutional Research at MCC (see Appendix B).

Table 5

Participating Sections of Student Development (SDV) in Dissertation Study

\begin{tabular}{lll}
\hline Number of SDV Sections & Session/Duration of Course & Number of Students \\
\hline 21 & 8 Weeks & 688 \\
1 & 14 Weeks & 17 \\
4 & 16 Weeks & 131 \\
\hline
\end{tabular}

Instrumentation. The data were collected from student participants through the use of a standard instrument called the College Student Expectations Questionnaire (CSXQ) authored by C. Robert Pace and George Kuh (1999) (see Appendix A). The CSXQ is a self-report instrument adapted from the College Student Experiences Questionnaire (CSEQ) and was first published in 1997. The second edition was published in 1999 and is the current edition used in this study. The survey took approximately 15-20 minutes to complete.

The CSXQ is designed to measure students' expectations about college as well as assess the quality of effort that students will dedicate toward educational activities. The research study used the College Activities scales which included: Library and Information Technology, Experiences with Faculty, Course Learning, Writing, Campus Facilities, Clubs, Organizations and Service Projects, Student Acquaintances and Scientific and Quantitative Experiences. Additional scales include students expectations related to Conversations and Reading/Writing was not used in this study. The Opinion about College question allowed students to share how well they believe they will like college, and this was used in the research. Lastly, the College 
Environment Scale allowed students to report to what extent they believed the institution will emphasize various scholarly and intellectual qualities as well as relationships with students, faculty, administrators, and staff.

Selected items from the College Activities scales (35 items in 7 topic scales) was used to measure the effort that students expected to participate in college activities and learning experiences. The scale also measured expectations in utilizing campus resources, personnel (faculty/staff/students) and facilities. The quality of effort scales measured as the following: $1=$ "Never," 2="Occasionally," 3="Often," and 4="Very Often." The categories of College Activities included Library and Information Technology (LIBIT 1-9); Experiences with Faculty (FAC1-4;6;8;10); Course Learning (CRSE1-3;5-6;8-11); Writing (WRITE 3-7); Campus Facilities (CAMRE 1-9); Clubs, Organizations, Service Projects (CLUBS 1-5); Student Acquaintances (STACQ 1-3;6-9); and Scientific and Quantitative Experiences (SCI 1-5). The Conversation scale measured how often students expected to discuss topics of conversations (CNTPS 1-10) and use information sources (CNINF 1-6) to formulate opinions or arguments. The same quality of effort scales ranging from $1=" N e v e r "$ to $4="$ Very Often" were used to measure these areas. The Reading/Writing section (READNON, READTXT, WRITTRM and WRITESS) asked students to gauge how much reading and writing do they plan to complete during the upcoming school year. The responses included: "None," "Fewer than 5," "Between 5 and 10," "Between 11 and 20," and "More than 20" based on different types of materials (books, textbooks, papers, and essay exams). The Opinion about College item asked students how well they believed they will like college. The responses were: "I will be enthusiastic about it;" "I will like it;" "I will be more or less neutral about it;" and "I won't like it." 
The College Environment section included two topic scales. The 10 items in these scales included word for word items related to the environmental emphasis and quality of relationships. The environmental emphasis scale allowed students to share the extent that the college environment will emphasize scholarly, intellectual and practical activities. The seven point scale ranged from 7="Strong Emphasis" to 1="Weak Emphasis." The quality of relationship scale referred to students, faculty members and administrative personnel/offices at the college and whether students feel that relationships among these people will be emphasized. The seven point scale ranged from 7="Friendly, Supportive, Sense of Belonging” to 1=“Competitive, Uninvolved, Sense of Alienation."

The last page of the CSXQ provided Background Information on students. Items included students' age, sex, transfer status, living arrangement, expectation of grades, educational attainment of parents, graduate school attendance, number of credit hours enrolled, academic major, participation in out of class activities, hours of employment, college expenses and race/ethnic identification. There were no locally developed items added to this study and students were not asked to provide their student ID numbers.

The CSXQ served as an appropriate instrument to the study of assessing students expectations of general education goals. Items pertained to quality of effort and emphasis on areas including communication, critical thinking, cultural and social understanding, information literacy, quantitative reasoning and scientific reasoning goals listed as requirements for the institution and the community college system. The CSXQ related items to the institution's general education goals are located in Table 6.

The CSXQ is a nationally administered instrument published by the Indiana University Center for Postsecondary Research. Using the CSXQ second edition national norms dataset 
including 38,000 students, Kuh, Gonyea and Williams (2005) computed the alpha reliability coefficient of the College Activities and Campus Environment Expectations as both .82 and .83 respectively. The coefficients of reliability indicate that each subscale measures the quality of effort and expectations with high degree of internal consistency. Validity is assured as the survey is based on the Quality of Effort theory authored by one of the survey developers, C. Robert Pace. The test assesses the scope of effort that students expect to dedicate towards learning activities. The content of the instrument is derived from the College Student Experiences Questionnaire (CSEQ) which has been used historically to assess students' experiences and used as a post-test to the CSXQ instrument.

\section{Data Collection Procedures}

The instrument was administered by the researcher during a three week time period of September $20^{\text {th }}$-October $8^{\text {th }}$ with the selected SDV courses for study. Distributing and completing the survey in the classroom provided the best response rate. Therefore, faculty was asked to allocate the first twenty minutes of class so that the researcher could collect the data. Students were provided with a script to be read before the survey was administered making them aware that this was a dissertation study and that their responses were voluntary, anonymous and did not affect their grade in the course. A cover letter (see Appendix C) was also included with each survey that provided students with the same information as the script. Eight hundred and thirty six students enrolled in these 26 special SDV sections for first year students last fall semester at five campuses. The goal was to receive at least $70 \%$ participation of students currently enrolled in the targeted sections. If this goal was not achieved, then the researcher would have extended the time for the study to return to any of the missed participating sections by October $14^{\text {th }}$. 
Surveys were sent to the Indiana University Center for Postsecondary Education and Research for special analysis. The center provided the researcher with the means/standard deviation for each item and frequencies for responses. It took six weeks for the special analysis to occur and was returned back to the researcher in November.

After the defense of the prospectus the researcher requested approval from West Virginia University's Institutional Review Board for the Protection of Human Subjects (IRB) under the Exempt category. Approval from the IRB was received prior to conducting the research at MultiCampus Community College. The researcher completed Ethics Training online through CITI Program as directed by the policies and procedures of the university.

\section{Data Analysis}

The mean scores, percentages and frequencies were calculated by the Indiana University Center for Postsecondary Research and sent to the researcher in a report binder which included: the frequencies and means for items and responses; codebook with survey questions, variable names and response options; and a disk containing raw data, SPSS output, SPSS Syntax and the electronic copy of the codebook.

The first research question (RQ1) addressed what general education goals (see Table 6) students expected to be emphasized at a community college. Descriptive statistics provided the means, frequencies and percentages of student responses from the first seven items on the College Environment Scales related to environmental emphasis. The seven point scale ranged from 7="Strong Emphasis" to 1="Weak Emphasis".

To analyze the second research question (RQ2) and related questions $(2 \mathrm{~A}, 2 \mathrm{~B}, 2 \mathrm{C}$ and 2D), selected items on the CSXQ College Activities scales were clustered based upon six of the general education goals of Multi-campus Community College (see previous Table 6) and served 
as the seven dependent variables for the study: Information Literacy, Communication, Critical

Thinking, Cultural and Social Understanding, Quantitative Reasoning, Scientific Reasoning and

Quantitative/Scientific Reasoning. MCC's general education goals are derived from the state community college system; however because some items on the survey were both strongly identified as scientific and quantitative reasoning, the extra category of Quantitative/Scientific

Reasoning was added.

Table 6

MCC's General Education Goals and Related CSXQ College Activity Scale Items

\begin{tabular}{lll}
\hline General Education Goal & CSXQ Variable & \multicolumn{1}{c}{ CSXQ Item } \\
\hline Information Literacy & Use of an index or database (computer, card \\
& catalog, etc.) to find material on some topic \\
LIBIT5 & Use a computer or word processor to prepare \\
& reports or papers \\
LIBIT8 & Search the World Wide Web or Internet for \\
& information related to a course \\
CRSE11 & Prepare a paper or project where you had to \\
CNTPS7 & integrate ideas from various sources \\
CRSE3 & Computers and other technologies \\
CRSE6 & Contribute to class discussions \\
& Summarize major points and information from \\
CRSE10 & your readings or class notes \\
& Explain material from course to someone else \\
& (another student, friend, co-worker, family \\
& member) \\
& Persuade others to change their minds as a result \\
& &
\end{tabular}


Table 6 (continued)

MCC's General Education Goals and Related CSXQ College Activity Scale Items

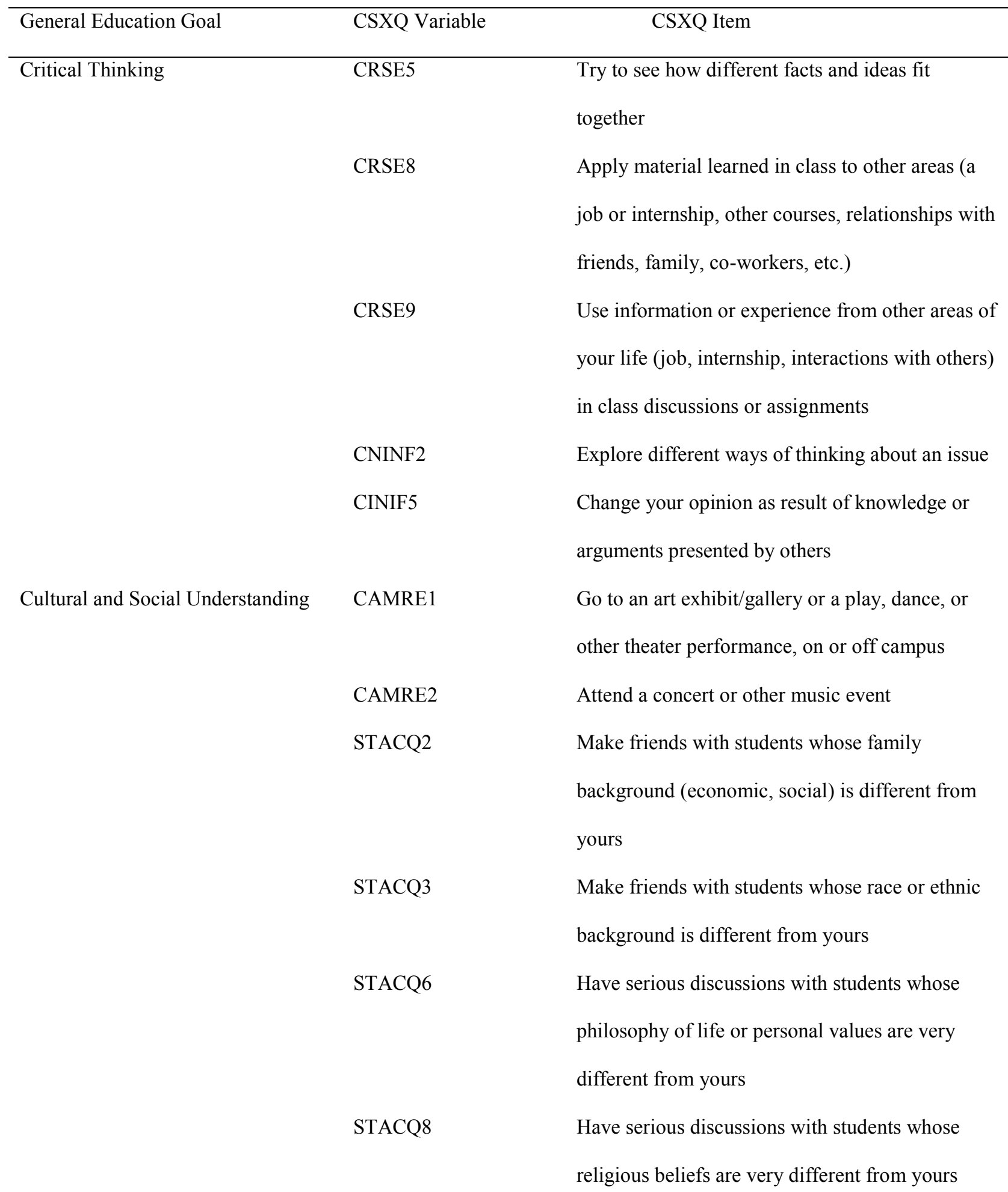


Table 6 (continued)

MCC's General Education Goals and Related CSXQ College Activity Scale Items

\begin{tabular}{|c|c|c|}
\hline General Education Goal & CSXQ Variable & CSXQ Item \\
\hline & STACQ7 & $\begin{array}{l}\text { Have serious discussions with students whose } \\
\text { political opinions are very different from yours }\end{array}$ \\
\hline & STACQ9 & $\begin{array}{l}\text { Have serious discussions with students whose } \\
\text { race or ethnic identification is very different from } \\
\text { yours }\end{array}$ \\
\hline & CNTPS2 & $\begin{array}{l}\text { Social issues such as peace, justice, human rights, } \\
\text { equality, race relations }\end{array}$ \\
\hline & CNTPS3 & Different lifestyles, customs, and religions \\
\hline & CNTPS4 & $\begin{array}{l}\text { The ideas and views of writers, philosophers, } \\
\text { historians }\end{array}$ \\
\hline & CNTPS5 & $\begin{array}{l}\text { The arts (painting, poetry, theatrical productions, } \\
\text { dance, symphony, movies, etc.) }\end{array}$ \\
\hline & CNPTS9 & $\begin{array}{l}\text { The economy (employment, wealth, poverty, } \\
\text { debt, trade, etc.) }\end{array}$ \\
\hline & CNPTS10 & $\begin{array}{l}\text { International relations (human rights, free trade, } \\
\text { military activities, political differences, etc.) }\end{array}$ \\
\hline Quantitative Reasoning & SCI1 & $\begin{array}{l}\text { Memorize formulas, definitions, technical terms } \\
\text { and concepts }\end{array}$ \\
\hline & $\mathrm{SCI} 2$ & $\begin{array}{l}\text { Express a set of relationships using mathematical } \\
\text { terms }\end{array}$ \\
\hline Scientific Reasoning & SCI5 & $\begin{array}{l}\text { Complete an experiment or project using } \\
\text { scientific methods }\end{array}$ \\
\hline & CNTPS6 & Science (theories, experiments, methods, etc.) \\
\hline
\end{tabular}


Table 6 (continued)

MCC's General Education Goals and Related CSXQ College Activity Scale Items

\begin{tabular}{lll}
\hline General Education Goal & \multicolumn{1}{c}{ CSXQ Item } \\
\hline CNPTS8 & Social and ethical issues related to science and \\
& technology such as energy, pollution, chemicals, \\
& genetics, military use \\
Quantitative and Scientific & SCI3 & Explain your understanding of some scientific or \\
Reasoning (combined) & mathematical theory, principle or concept to \\
& & someone else (classmate, co-worker, etc.) \\
& SCI4 & Read articles about scientific or mathematical \\
& theories or concepts in addition to those assigned \\
& for a class
\end{tabular}

To analyze the second research question (RQ2), descriptive statistics provided the mean score for each general education cluster. The three major student groups for the study were also categorized based upon the independent variables: parents' education, employment, college opinion and academic major.

The first independent variable, Parents' Education (RQ2A), was determined by the CSXQ item which asked students if either of their parents graduated from college. The researcher gleaned three groups from this survey. The first group named "Yes, Both Parents" consisted of students who selected "yes, both parents". The next group "Yes, One Parent" included students who selected yes to either mother or father. The last group "No" consisted of the students whose parents have not graduated from college. Students who choose "Don't Know" were excluded. The seven dependent variables were the general education goals. 
The second independent variable, Employment (RQ2B), was derived from the item pertaining to the hours that students plan to work per week off campus. The researcher was able to assemble three groups from the survey. The first student group named "None" included students who reported they will not have an off campus job. The second student group named "1-20 hours weekly" included students who work 1 to 20 hours a week (off campus). The third student group named "21 or more hours weekly" consisted of students who will work 21 or more hours a week (off campus).

The third independent variable, College Opinion (RQ2C), was selected from the responses to the items asking students how well they believe they will like college. The researcher created three groups from the survey. The first group named "Enthusiastic" included students who responded that they will be enthusiastic about college. The second group named "Like" consisted of students who responded that they will like college. The last group "Not Like/Neutral" included those students who expected to be neutral or not like college.

The fourth independent variable, Academic Major (RQ2D), is determined by the students' answers to the background question on the CSXQ asking their intended academic major. The research gleaned six groups from the survey:

- Liberal Arts/General Studies-additional majors to this group included the responses of Communication; Ethnic, Culture and Area Studies; Foreign Languages and Literature; History; Social Sciences; Humanities; and Visual and Performing Arts

- Math, Science and Engineering- additional majors to this group included the responses of Biological/Life Sciences; Computer and Information Science; Engineering; and Physical Sciences 
- Business and Public Services- additional majors to this group included the responses of Public Administration and Parks, Recreation, Leisure and Sports Management

- Healthcare

- Education

- Pre-Professional Studies

The technique for analyzing group differences of Parents' Education, Employment, College Opinion, and Academic Major was Analysis of Variance (ANOVA) for each General Education Cluster (see Table 7). The researcher had anticipated that there would be sufficient responses to formulate three or more groups for each independent variable.

\section{Table 7}

Research Questions 2A-D Variables and Analysis

\begin{tabular}{|c|c|c|c|c|}
\hline Research & Dependent & Independent & Independent Variable Groups & Data Analysis \\
\hline Question & Variable & Variables & & \\
\hline \multirow[t]{3}{*}{$2 \mathrm{~A}$} & 7 General & Parent Educational & - Both Parents & 7 ANOVA- \\
\hline & Education Goals & Attainment & - One Parent & GE Goals \\
\hline & & & - No Parent & \\
\hline \multirow[t]{3}{*}{$2 \mathrm{~B}$} & 7 General & Employment & - None & 7 ANOVA- \\
\hline & Education Goals & & - $1-20$ hrs weekly & GE Goals \\
\hline & & & - 21 or more hrs weekly & \\
\hline \multirow[t]{2}{*}{$2 \mathrm{C}$} & 7 General & Opinion of College & - Enthusiastic & 7 ANOVA- \\
\hline & Education Goals & & - Like & GE Goals \\
\hline
\end{tabular}


Table 7 (continued)

Research Questions 2A-D Variables and Analysis

\begin{tabular}{|c|c|c|c|c|}
\hline $\begin{array}{l}\text { Research } \\
\text { Question }\end{array}$ & $\begin{array}{l}\text { Dependent } \\
\text { Variable }\end{array}$ & $\begin{array}{l}\text { Independent } \\
\text { Variables }\end{array}$ & $\begin{array}{l}\text { Independent Variable } \\
\text { Groups }\end{array}$ & Data Analysis \\
\hline $2 \mathrm{D}$ & $\begin{array}{l}7 \text { General } \\
\text { Education Goals }\end{array}$ & Academic Major & $\begin{array}{ll}\text { - } & \text { Business \& Public } \\
\text { - } & \text { Services } \\
\text { - } & \text { Enginh, Science and } \\
\text { - } & \text { Hiberal Arts/General } \\
\text { - } & \text { Edudies } \\
\text { - } & \text { Pre-Professional } \\
\text { Studies }\end{array}$ & $\begin{array}{l}7 \text { ANOVA- } \\
\text { GE Goals }\end{array}$ \\
\hline
\end{tabular}

\section{Limitations}

There were several limitations of the study. This study was completed at a public, comprehensive, community college in a large metropolitan area. One limitation to the study was that the results may not be applicable to other community colleges with different institutional characteristics and four year institutions. A second limitation was that students' self-reported perceptions may change over time and could be shaped by various experiences as stated in aforementioned student development theories. Finally, the participants were also a sample of convenience of students participating in special programs for first year community college students. Therefore, the expectations of first time students who were not participants in such programs were excluded. 


\section{CHAPTER FOUR}

\section{Results}

\section{Overview}

This chapter presents the results of the survey research. First, an overview of the survey process is provided. Second, the student demographic information is presented. Finally, the data are discussed according to each research question.

\section{Survey Process}

The researcher visited 26 sections of Student Development (SDV) courses at MultiCampus Community College (MCC) during the $4^{\text {th }}$ through $6^{\text {th }}$ weeks of Fall 2010 semester to administer the College Student Expectations Questionnaire (CSXQ) (1999). There were 836 students enrolled in these selected sections of SDV courses during the research study according to the college's online enrollment management system.

At the beginning of the selected SDV class period, the researcher distributed the surveys to 701 students. Approximately 20 minutes later she collected completed surveys from 665 students. The response rate was 79.5\% (665/836). Throughout this study, all students did not answer each survey item. Therefore, the total number of respondents varies by survey item.

\section{Respondent Characteristics}

At the end of the survey, students were asked to respond to series of items which provided student characteristics (including demographic data), enrollment characteristics, work and funding information, and academic characteristics of participants.

Age. A large majority (90\%) of students participating in the study was 19 years old or younger (see Table 8). 
Table 8

Age of Participating Students

\begin{tabular}{lcc}
\hline Age & $n$ & $\%$ \\
\hline 19 or younger & 563 & $90 \%$ \\
$20-23$ & 40 & $6 \%$ \\
$24-29$ & 9 & $0 \%$ \\
$30-39$ & 3 & $1 \%$ \\
$40-55$ & 4 & $1 \%$ \\
Over 55 & 4 & \\
\hline
\end{tabular}

Note. $\mathrm{N}=623$. Total of percentages is not 100 because of rounding.

Gender. There was almost an equal distribution by gender of respondents with slightly more female student participants (51\%) (see Table 9).

Table 9

Gender of Participating Students

\begin{tabular}{lll}
\hline Gender & $n$ & $\%$ \\
\hline Female & 315 & $51 \%$ \\
Male & 303 & $49 \%$
\end{tabular}

Note. $\mathrm{N}=618$.

Racial/ethnic identification. There was a diverse population of students who participated in this study. The majority of respondents identified themselves as Other Hispanic (25\%). If respondents identifying themselves as Mexican American (2\%) and Puerto Rican (2\%) are merged with this group, then the students of Hispanic ethnicity represented the largest percentage of survey respondents. Twenty-three percent of respondents identified themselves as 
Caucasian, and $16 \%$ of respondents identified themselves as Asian or Pacific Islander (see Table $10)$.

Table 10

Response to Student Characteristics: Racial/Ethnic Identification

\begin{tabular}{lll}
\hline Racial/Ethnic Identification & $n$ & $\%$ \\
\hline Other Hispanic & 153 & $25 \%$ \\
Caucasian (other than Hispanic) & 164 & $23 \%$ \\
Asian or Pacific Islander & 99 & $16 \%$ \\
Black of African American & 78 & $13 \%$ \\
Other & 42 & $7 \%$ \\
Multiracial & 35 & $6 \%$ \\
American Indian/Native American & 18 & $3 \%$ \\
Mexican American & 14 & $2 \%$ \\
Puerto-Rican & 11 & $2 \%$ \\
\hline
\end{tabular}

Note. $\mathrm{N}=614$. Total of percentages is not 100 because of rounding.

Parents' education. Almost half (45\%) of all respondents reported that neither parent had graduated from college. Twenty-eight percent of respondents indicated that both parents graduated from college. If only one parent graduated from college, the father $(12 \%)$ was reported more often than the mother $(8 \%)$ (see Table 11$)$. The results to this item were used to analyze research question $2 \mathrm{a}$ that is reported later in this chapter. 
FIRST YEAR STUDENT EXPECTATIONS

Table 11

Parents’ Education for Participating Students

\begin{tabular}{lcc}
\hline Parents' College Graduates & $n$ & $\%$ \\
\hline No & 264 & $45 \%$ \\
Yes, both parents & 164 & $28 \%$ \\
Yes, father only & 69 & $12 \%$ \\
Yes, mother only & 47 & $8 \%$ \\
Don't know & 37 & $6 \%$
\end{tabular}

Note. $\mathrm{N}=581$. Total of percentages is not 100 because of rounding.

Residence. A large majority of respondents reported that they live within driving distance of the college during the school year (88\%) (see Table 12).

Table 12

Residence of Participating Students

\begin{tabular}{lcc}
\hline Residence & $n$ & $\%$ \\
\hline Residence within driving distance & 517 & $88 \%$ \\
Residence within walking distance & 54 & $9 \%$ \\
Fraternity or sorority house & 8 & $1 \%$ \\
Dormitory/other campus housing & 6 & $1 \%$
\end{tabular}

Note. $\mathrm{N}=585$. Total of percentages is not 100 because of rounding.

Students beginning college at MCC. Almost all of the respondents indicated that they were starting college at MCC (99\%) (see Table 13). Therefore, there were nearly no transfer students in this study. 
Table 13

Enrollment Characteristics for Participating Students

\begin{tabular}{lcc}
\hline Student Type & $n$ & $\%$ \\
\hline Starting here & 610 & $99 \%$ \\
Transferred here & 8 & $1 \%$ \\
\hline
\end{tabular}

Note. $\mathrm{N}=618$

Semester credit hour enrollment. Respondents indicated how many credit hours they planned to take in the current Fall 2010 semester. Eighty-two percent of the students were planning to pursue their college studies full time (see Table 14). At MCC, 12 credits or more constitutes full-time enrollment.

Table 14

Semester Credit Hour Enrollments of Participating Students

\begin{tabular}{lcc}
\hline Amount of Credit Hours & $n$ & $\%$ \\
\hline 6 or fewer & 39 & $7 \%$ \\
$7-11$ & 65 & $53 \%$ \\
$12-14$ & 302 & $22 \%$ \\
$15-16$ & 124 & $7 \%$ \\
17 or more & 39 & \\
\hline
\end{tabular}

Note. $\mathrm{N}=569$.

Work on-campus. Nearly three quarters (74\%) of students indicated that they did not have a job on campus. The respondents who reported working on campus were primarily parttime working between 1 to 10 hours per week (13\%) or 11 to 20 hours per week (10\%) (see Table 15). 
Table 15

Work Hours On-Campus of Participating Students

\begin{tabular}{lcc}
\hline Work Status/Hours & $n$ & $\%$ \\
\hline None; I won't have a job & 157 & $74 \%$ \\
$1-10$ hours a week & 29 & $13 \%$ \\
$11-20$ hours a week & 21 & $10 \%$ \\
$21-30$ hours a week & 4 & $1 \%$ \\
$31-40$ hours a week & 3 & $0 \%$ \\
More than 40 hours & 1 &
\end{tabular}

Note. $\mathrm{N}=215$.

Work off-campus. Approximately one-quarter of the participating students reported they worked off-campus either 21 to 30 hours per week or 11 to 20 hours per week. Nearly another one quarter (24\%) of the students did not have an off-campus job (see Table 16). The results to this item were used to analyze research question $2 b$ that is reported later in this chapter.

Table 16

Work Hours Off-Campus of Part-time Students

\begin{tabular}{lcc}
\hline Work Status/Hours & $n$ & $\%$ \\
\hline None; I won't have a job & 117 & $24 \%$ \\
$1-10$ hours a week & 75 & $15 \%$ \\
$11-20$ hours a week & 117 & $24 \%$ \\
$21-30$ hours a week & 128 & $26 \%$ \\
$31-40$ hours a week & 43 & $7 \%$ \\
More than 40 hours & 15 & $3 \%$ \\
\hline
\end{tabular}

Note. $\mathrm{N}=495$. Total of percentages is not 100 because of rounding. 
College funding. Forty-four percent of respondents expected that all or nearly all of their college expenses will be provided by their parents and family; however, approximately a quarter $(26 \%)$ of respondents expected none to very little college expenses to be provided (see Table 17).

Table 17

College Funding of Participating Students

\begin{tabular}{lcc}
\hline Provided by Parents or Family & $n$ & $\%$ \\
\hline All or nearly all & 233 & $44 \%$ \\
None or very little & 135 & $26 \%$ \\
More than half & 100 & $20 \%$ \\
Less than half & 61 & $12 \%$
\end{tabular}

Note. $\mathrm{N}=529$. Total of percentages is not 100 because of rounding.

Academic major. MCC offers more than 160 degrees at the associate's level and certificate programs. Fourteen percent of student respondents expected to major in Healthrelated fields $(14 \%)$ or Business $(14 \%)$. Ten percent of the students expected to major in Computer and Information Science while another 8\% expected to major in Engineering or the Social Sciences (see Table 18). The results to this item were used to analyze Research Question $2 \mathrm{~d}$. 


\section{Table 18}

Intended Academic Major of Participating Students

\begin{tabular}{|c|c|c|}
\hline Academic Major & $n$ & $\%$ \\
\hline Health-related fields & 74 & $14 \%$ \\
\hline Business & 72 & $14 \%$ \\
\hline Computer and information science & 50 & $10 \%$ \\
\hline Other & 47 & $9 \%$ \\
\hline Social sciences & 44 & $8 \%$ \\
\hline Engineering & 42 & $8 \%$ \\
\hline Undecided & 37 & $7 \%$ \\
\hline Education & 30 & $6 \%$ \\
\hline Biological/Life Sciences & 26 & $5 \%$ \\
\hline Liberal/general studies & 23 & $4 \%$ \\
\hline Visual and performing arts & 19 & $4 \%$ \\
\hline Pre-professional & 12 & $2 \%$ \\
\hline Physical sciences & 10 & $2 \%$ \\
\hline Public administration & 10 & $2 \%$ \\
\hline Communication & 8 & $2 \%$ \\
\hline Humanities & 3 & $1 \%$ \\
\hline Mathematics & 3 & $1 \%$ \\
\hline Foreign languages and literature & 3 & $1 \%$ \\
\hline Ethnic, cultural and area studies & 2 & $0 \%$ \\
\hline History & 2 & $0 \%$ \\
\hline Multi/interdisciplinary studies & 2 & $0 \%$ \\
\hline Parks, rec., leisure, sports mgmt. & 1 & $0 \%$ \\
\hline
\end{tabular}

Note. $\mathrm{N}=520$. Majors with no response were excluded. 
Expected hours spent on outside class activities. Approximately one-third of respondents indicated that they would spend 6 to 10 hours a week on outside of class activities related to their academic program (see Table 19). Such activities include studying, writing, reading, lab work, and rehearsing.

Table 19

Expected Hours Spent on Outside Class Activities

\begin{tabular}{lcc}
\hline Hours Per Week & $n$ & $\%$ \\
\hline 5 or fewer hours a week & 105 & $19 \%$ \\
6 -10 hours a week & 182 & $33 \%$ \\
$11-15$ hours a week & 120 & $22 \%$ \\
$16-20$ hours a week & 75 & $14 \%$ \\
$21-25$ hours a week & 44 & $8 \%$ \\
$26-30$ hours a week & 11 & $2 \%$ \\
More than 30 hours a week & 10 & $2 \%$ \\
\hline
\end{tabular}

Note. $\mathrm{N}=547$.

Expected grade point average. Forty-three percent of student respondents expected their college grade point average to be in the range of $\mathrm{A}-\mathrm{B}+$ at the end of the first year (see Table 20). 
Table 20

Expected Grade Point Average of Participating Students

\begin{tabular}{lcc}
\hline Grade Point Average & $n$ & $\%$ \\
\hline $\mathrm{A}$ & 90 & $15 \%$ \\
$\mathrm{~A}-/ \mathrm{B}+$ & 250 & $43 \%$ \\
$\mathrm{~B}$ & 127 & $22 \%$ \\
$\mathrm{~B}-/ \mathrm{C}+$ & 109 & $19 \%$ \\
$\mathrm{C}, \mathrm{C}-$, or lower & 8 & $1 \%$
\end{tabular}

Note. $\mathrm{N}=584$. Total of percentages is not 100 because of rounding.

Expectation to enroll in an advanced degree. A majority ( $86 \%)$ of student respondents expected to enroll for in advanced degree program when they complete their undergraduate degree (see Table 21).

Table 21

Expectation to Enroll in Advanced Degree of Participating Students

\begin{tabular}{lcc}
\hline & $n$ & $\%$ \\
\hline Yes & 487 & $86 \%$ \\
No & 81 & $14 \%$ \\
\hline
\end{tabular}

Note. $\mathrm{N}=568$.

\section{Research Question 1}

The first research question asked was, "What general education goals do students expect to be emphasized in the community college environment?" The first seven items of the College Environment Scale allowed respondents to report how much emphasis they believe the college will place upon learning goals. This research question was answered by providing the means and 
the frequencies for the first seven items (see Table 22 and 23). The Likert-type scale responses ranged from 7 (Strong Emphasis) to 1 (Weak Emphasis).

The majority of student respondents indicated that MCC would place a moderate to strong emphasis on the seven learning goals (see Table 22).

Table 22

Environmental Emphasis on General Education Goals

\begin{tabular}{|c|c|c|c|c|c|c|c|c|c|c|c|c|c|c|c|c|}
\hline & \multicolumn{2}{|c|}{$\begin{array}{l}\text { 7- } \\
\text { Strong }\end{array}$} & \multicolumn{2}{|l|}{6} & \multicolumn{2}{|l|}{5} & \multicolumn{2}{|l|}{4} & \multicolumn{2}{|l|}{3} & \multicolumn{2}{|l|}{2} & \multicolumn{2}{|c|}{$\begin{array}{l}1- \\
\text { Weak }\end{array}$} & \multicolumn{2}{|c|}{ Total } \\
\hline & $n$ & $\%$ & $n$ & $\%$ & $n$ & $\%$ & $n$ & $\%$ & $n$ & $\%$ & $n$ & $\%$ & $n$ & $\%$ & $n$ & $\%$ \\
\hline $\begin{array}{l}\text { Emphasis on developing } \\
\text { academic, scholarly, and } \\
\text { intellectual qualities }\end{array}$ & 150 & 25 & 140 & 24 & 153 & 26 & 119 & 20 & 19 & 3 & 8 & 1 & 5 & 1 & 594 & 100 \\
\hline $\begin{array}{l}\text { Emphasis on developing } \\
\text { aesthetic, expressive, and } \\
\text { creative qualities }\end{array}$ & 103 & 17 & 131 & 22 & 180 & 30 & 121 & 20 & 44 & 7 & 10 & 2 & 3 & 1 & 592 & 100 \\
\hline $\begin{array}{l}\text { Emphasis on developing } \\
\text { critical, evaluative, and } \\
\text { analytical qualities }\end{array}$ & 137 & 23 & 127 & 22 & 153 & 26 & 112 & 19 & 43 & 7 & 13 & 2 & 4 & 1 & 589 & 100 \\
\hline $\begin{array}{l}\text { Emphasis on developing } \\
\text { an understanding and } \\
\text { appreciation of human } \\
\text { diversity }\end{array}$ & 161 & 27 & 144 & 24 & 132 & 22 & 96 & 16 & 38 & 6 & 11 & 2 & 9 & 2 & 591 & 100 \\
\hline $\begin{array}{l}\text { Emphasis on developing } \\
\text { information literacy skills } \\
\text { (using computers, other } \\
\text { information resources) }\end{array}$ & 173 & 29 & 144 & 24 & 133 & 23 & 95 & 16 & 30 & 5 & 9 & 2 & 7 & 1 & 591 & 100 \\
\hline $\begin{array}{l}\text { Emphasis on developing } \\
\text { vocational and } \\
\text { occupational competence }\end{array}$ & 102 & 17 & 112 & 19 & 155 & 26 & 158 & 27 & 33 & 6 & 18 & 3 & 11 & 2 & 589 & 100 \\
\hline $\begin{array}{l}\text { Emphasis on the personal } \\
\text { relevance and practical } \\
\text { value of your courses }\end{array}$ & 129 & 22 & 138 & 24 & 143 & 24 & 119 & 20 & 38 & 7 & 11 & 2 & 9 & 2 & 587 & 100 \\
\hline
\end{tabular}

Note. Total of percentages is not 100 because of rounding.

The "development of information literacy skills" (mean 5.47) was the area in which students reported the most responses of strong emphasis (29\%)(see Table 23). The "development of academic, scholarly and intellectual qualities" (mean 5.40) was second followed by "understanding and appreciation of human diversity" (5.37). Emphasis on "developing vocational and occupational competence" had the lowest mean (4.99) of the seven items. 
Table 23

CSXQ Means: Environmental Emphasis on General Education Goals

\begin{tabular}{|c|c|c|c|}
\hline & $n$ & Mean & $\begin{array}{l}\text { Standard } \\
\text { Deviation }\end{array}$ \\
\hline $\begin{array}{l}\text { Emphasis on developing information literacy skills (using computers, other information } \\
\text { resources) }\end{array}$ & 599 & 5.47 & 1.380 \\
\hline Emphasis on developing academic, scholarly, and intellectual qualities & 605 & 5.40 & 1.293 \\
\hline Emphasis on developing an understanding and appreciation of human diversity & 599 & 5.37 & 1.429 \\
\hline Emphasis on developing critical, evaluative, and analytical qualities & 597 & 5.25 & 1.366 \\
\hline Emphasis on the personal relevance and practical value of your courses & 595 & 5.22 & 1.391 \\
\hline Emphasis on developing aesthetic, expressive, and creative qualities & 601 & 5.14 & 1.290 \\
\hline Emphasis on developing vocational and occupational competence & 597 & 4.99 & 1.395 \\
\hline
\end{tabular}

\section{Research Question 2}

The second research question examined how much effort students expected to apply

toward general education goals. To examine the second research question, the means comprising the seven clusters of general education goals were calculated (see Table 24). The seven clusters were grouped based upon 35 selected items of the College Activities Scale that were related to a general education goal: Information Literacy, Communication, Critical Thinking, Cultural and Social Understanding, Quantitative Reasoning, Scientific Reasoning, and Quantitative/Scientific Reasoning. Quality of effort scale items utilized a Likert scale ranging from 1=Never to 4=Very Often. For Information Literacy, Communication, and Critical Thinking, students reported they expected to do these activities often. However, for the area of Cultural and Social Understanding, only six activities were reported to occur often:

- Make friends with students whose family background (economic, social) is different from yours 
- Make friends with students whose race or ethnic background is different from yours

- Have serious discussions with students whose philosophy of life or personal values are very different from yours

- Discuss different lifestyles, customs, and religions

For the remaining six items in this category, the respondents reported doing these activities only occasionally. For Scientific Reasoning and Quantitative/Scientific Reasoning, most students reported only occasionally doing these activities. For Quantitative Reasoning, students only expected to occasionally memorize formulas, definitions, technical terms, and concepts.

Table 24

CSXQ Means of the College Activity Items Related to General Education Goals

\begin{tabular}{|c|c|c|c|c|}
\hline CSXQ Variable & $n$ & $M$ & SEM & $S D$ \\
\hline \multicolumn{5}{|c|}{ Information Literacy } \\
\hline $\begin{array}{l}\text { LIBIT2- Use index or database to find } \\
\text { material }\end{array}$ & 655 & 2.75 & .038 & .972 \\
\hline $\begin{array}{l}\text { LIBIT5- Use computer-word processor } \\
\text { for paper }\end{array}$ & 653 & 3.54 & .030 & .775 \\
\hline $\begin{array}{l}\text { LIBIT8- Search internet for course } \\
\text { material }\end{array}$ & 651 & 3.34 & .034 & .866 \\
\hline $\begin{array}{l}\text { CRSE11- Work on project integrating } \\
\text { ideas }\end{array}$ & 655 & 2.83 & .033 & .838 \\
\hline $\begin{array}{l}\text { CNTPS7- Topic: Computers and other } \\
\text { technologies }\end{array}$ & 633 & 2.52 & .039 & .971 \\
\hline \multicolumn{5}{|c|}{ Communication } \\
\hline CRSE3- Contribute to class discussions & 652 & 2.81 & .032 & .828 \\
\hline $\begin{array}{l}\text { CRSE6- Summarize major points and } \\
\text { information }\end{array}$ & 646 & 2.81 & .034 & .874 \\
\hline $\begin{array}{l}\text { CRSE10- Explain course material to } \\
\text { others }\end{array}$ & 656 & 2.73 & .033 & .848 \\
\hline $\begin{array}{l}\text { CINIF6- Persuade others to change } \\
\text { their minds }\end{array}$ & 637 & 2.56 & .034 & .862 \\
\hline \multicolumn{5}{|c|}{ Critical Thinking } \\
\hline $\begin{array}{l}\text { CRSE5- Put together different facts and } \\
\text { ideas }\end{array}$ & 647 & 2.93 & .032 & .807 \\
\hline $\begin{array}{l}\text { CRSE8- Apply class material to other } \\
\text { areas }\end{array}$ & 656 & 2.89 & .036 & .913 \\
\hline $\begin{array}{l}\text { CRSE9- Use info from other areas in } \\
\text { class }\end{array}$ & 655 & 2.90 & .034 & .879 \\
\hline
\end{tabular}


Table 24 (continued)

\section{CSXQ Means of the College Activity Items Related to General Education Goals}

\begin{tabular}{|c|c|c|c|c|}
\hline CSXQ Variable & $n$ & $M$ & SEM & $S D$ \\
\hline \multicolumn{5}{|c|}{ Critical Thinking } \\
\hline $\begin{array}{l}\text { CNINF2- Explore different ways of } \\
\text { thinking }\end{array}$ & 630 & 2.83 & .034 & .857 \\
\hline $\begin{array}{l}\text { CINIF5- Change opinion because of } \\
\text { others }\end{array}$ & 639 & 2.37 & .031 & .787 \\
\hline \multicolumn{5}{|c|}{ Cultural and Social Understanding } \\
\hline $\begin{array}{l}\text { CAMRE1- Go to exhibit-gallery- } \\
\text { performance }\end{array}$ & 655 & 1.82 & .036 & .918 \\
\hline $\begin{array}{l}\text { CAMRE2- Attend a concert or other } \\
\text { music event }\end{array}$ & 652 & 1.97 & .037 & .948 \\
\hline $\begin{array}{l}\text { STACQ2- Acquainted: students of diff } \\
\text { background }\end{array}$ & 653 & 2.97 & .033 & .833 \\
\hline $\begin{array}{l}\text { STACQ3- Acquainted: students of diff } \\
\text { race }\end{array}$ & 652 & 3.17 & .032 & .805 \\
\hline $\begin{array}{l}\text { STACQ6- Discussions: students of diff } \\
\text { values }\end{array}$ & 655 & 2.65 & .037 & .955 \\
\hline $\begin{array}{l}\text { STACQ8- Discussions: students of diff } \\
\text { religious }\end{array}$ & 654 & 2.41 & .041 & 1.045 \\
\hline $\begin{array}{l}\text { STACQ7- Discussions: students of diff } \\
\text { political }\end{array}$ & 640 & 2.27 & .040 & 1.006 \\
\hline $\begin{array}{l}\text { STACQ9- Discussions: students of diff } \\
\text { race }\end{array}$ & 640 & 2.50 & .041 & 1.027 \\
\hline $\begin{array}{l}\text { CNTPS2- Topic: Social issues-- } \\
\text { peace,justice, etc. }\end{array}$ & 644 & 2.45 & .035 & .893 \\
\hline $\begin{array}{l}\text { CNTPS3- Topic: Different lifestyles, } \\
\text { etc. }\end{array}$ & 636 & 2.56 & .035 & .886 \\
\hline CNTPS4- Topic: Ideas of writers, etc. & 637 & 2.13 & .037 & .944 \\
\hline $\begin{array}{l}\text { CNTPS5- Topic: The arts--painting, } \\
\text { poetry, etc. }\end{array}$ & 638 & 2.32 & .038 & .968 \\
\hline $\begin{array}{l}\text { CNPTS9- Topic: The economy-- } \\
\text { employment, etc. }\end{array}$ & 634 & 2.50 & .036 & .905 \\
\hline $\begin{array}{l}\text { CNPTS10- Topic: International } \\
\text { relations }\end{array}$ & 638 & 2.34 & .038 & .967 \\
\hline \multicolumn{5}{|c|}{ Quantitative } \\
\hline $\begin{array}{l}\text { SCI1- Memorize formulas-definitions- } \\
\text { concepts }\end{array}$ & 640 & 2.86 & .035 & .896 \\
\hline $\begin{array}{l}\text { SCI2- Express relationships using math } \\
\text { terms }\end{array}$ & 640 & 2.48 & .039 & .985 \\
\hline \multicolumn{5}{|c|}{$\begin{array}{l}\text { Scientific Reasoning } \\
\end{array}$} \\
\hline $\begin{array}{l}\text { SCI5- Complete an experiment w-sci } \\
\text { methods }\end{array}$ & 637 & 2.29 & .040 & 1.002 \\
\hline CNTPS6- Topic: Science--theories, etc. & 634 & 2.02 & .037 & .935 \\
\hline $\begin{array}{l}\text { CNPTS8- Topic: Social-ethical issues } \\
\text { re: science }\end{array}$ & 640 & 2.26 & .037 & .932 \\
\hline \multicolumn{5}{|c|}{ Quantitative and Scientific } \\
\hline $\begin{array}{l}\text { SCI3- Explain scientific concept to } \\
\text { others }\end{array}$ & 638 & 2.36 & .038 & .954 \\
\hline $\begin{array}{l}\text { SCI4- Read articles about science not } \\
\text { assigned }\end{array}$ & 638 & 2.09 & .039 & .984 \\
\hline
\end{tabular}




\section{Research Question 2A: Parents’ Education}

This research question 2A looked for significant differences in the CSXQ General Education Variables based upon parents' educational attainment. A one-way analysis of variance (ANOVA) was calculated to examine the effect of parents' education on student expectations of college. Data for the Parents' Education variable were derived from the CSXQ item which asked students if either of their parents graduated from college. Three groups were created based upon the students' responses. The first group named "No" $(n=264)$ consisted of the students whose parents did not graduate from college. The next group "Yes, Both Parents" $(n=164)$ consisted of students who responded that both parents graduated from college. The last group "Yes, One Parent" ( $\mathrm{n}=116)$ included students who selected yes to either the mother or the father who graduated from college. A statistically significant effect was found with six items in four general education clusters: Communication, Cultural and Social Understanding, Scientific Reasoning, and Quantitative/Scientific Reasoning.

Parents' education/information literacy. Analysis of Variance (ANOVA) examined significant differences in Parents' Education (independent variable) by the means of the Information Literacy CSXQ College Activity Items (dependent variables). This Information Literacy cluster analysis yielded no significant differences (see Table 25). 
Table 25

Means, Standard Deviations, and One-Way Analysis of Variance for the Effects of Parents' Education on Information Literacy CSXQ Variables

\begin{tabular}{|c|c|c|c|c|c|c|c|c|c|c|}
\hline \multirow[b]{2}{*}{ Variable } & \multicolumn{2}{|l|}{ No } & \multicolumn{2}{|c|}{$\begin{array}{l}\text { Yes, Both } \\
\text { Parents }\end{array}$} & \multicolumn{2}{|c|}{$\begin{array}{l}\text { Yes, One } \\
\text { Parent }\end{array}$} & \multirow[b]{2}{*}{$d f$} & \multirow[b]{2}{*}{$F$} & \multirow[b]{2}{*}{$p$} & \multirow[b]{2}{*}{$\eta^{2}$} \\
\hline & $M$ & $S D$ & $M$ & $S D$ & $M$ & $S D$ & & & & \\
\hline $\begin{array}{l}\text { LIBIT2- Use index or database } \\
\text { to find material }\end{array}$ & 2.84 & .979 & 2.74 & .974 & 2.62 & .996 & $2 / 533$ & 2.103 & .123 & .01 \\
\hline $\begin{array}{l}\text { LIBIT5- Use computer-word } \\
\text { processor for paper }\end{array}$ & 3.60 & .725 & 3.47 & .825 & 3.59 & .685 & $2 / 533$ & 1.635 & 196 & .01 \\
\hline $\begin{array}{l}\text { LIBIT8- Search internet for } \\
\text { course material }\end{array}$ & 3.40 & .823 & 3.36 & .846 & 3.35 & .877 & $2 / 529$ & .164 & .848 & .00 \\
\hline $\begin{array}{l}\text { CRSE11- Work on project } \\
\text { integrating ideas }\end{array}$ & 2.88 & .846 & 2.79 & .840 & 116 & .843 & $2 / 534$ & .505 & .604 & .00 \\
\hline $\begin{array}{l}\text { CNTPS7- Topic: Computers } \\
\text { and other technologies }\end{array}$ & 2.53 & 1.015 & 2.48 & .962 & 2.60 & .907 & $2 / 529$ & .488 & .614 & .00 \\
\hline
\end{tabular}

$* \mathrm{p}<.05 . \eta^{2}$ is rounded

Parents' education/communication. Analysis of Variance (ANOVA) examined significant differences in Parents' Education (independent variable) by the means of the Communication CSXQ College Activity Items (dependent variables). This analysis yielded one item with a significant difference (see Table 26). For the item "CINIF6-Persuade others to change their minds" this ANOVA produced a significant overall finding $\mathrm{F}(2 / 534)=4.112, p<$ .05 . When the Tukey multiple comparison follow-up test was computed, it indicated a significant difference $(p=.012)$ in means between the No $(M=2.66)$ and Yes, Both Parents $(\mathrm{M}=2.41)$ groups. This finding shows that students who had no parents graduating from college significantly more often expected to persuade others to "change their minds as a result of the knowledge or arguments cited" than the students who had both parents graduating from college. 
Table 26

Means, Standard Deviations, and One-Way Analysis of Variance for the Effects of Parents' Education on Communication CSXQ Variables

\begin{tabular}{|c|c|c|c|c|c|c|c|c|c|c|}
\hline \multirow[b]{2}{*}{ Variable } & \multicolumn{2}{|l|}{ No } & \multicolumn{2}{|c|}{$\begin{array}{l}\text { Yes, Both } \\
\text { Parents }\end{array}$} & \multicolumn{2}{|c|}{$\begin{array}{l}\text { Yes, One } \\
\text { Parent }\end{array}$} & \multirow[b]{2}{*}{$D f$} & \multirow[b]{2}{*}{$F$} & \multirow[b]{2}{*}{$p$} & \multirow[b]{2}{*}{$\eta^{2}$} \\
\hline & $M$ & $S D$ & $M$ & $S D$ & $M$ & $S D$ & & & & \\
\hline $\begin{array}{l}\text { CRSE3- Contribute } \\
\text { to class discussions }\end{array}$ & 2.80 & .819 & 2.87 & .810 & 2.87 & .850 & $2 / 533$ & .479 & .620 & .00 \\
\hline $\begin{array}{l}\text { CRSE6- Summarize } \\
\text { major points and } \\
\text { information }\end{array}$ & 2.85 & .866 & 2.79 & .869 & 2.84 & .830 & $2 / 530$ & .256 & .774 & .00 \\
\hline $\begin{array}{l}\text { CRSE10- Explain } \\
\text { course material to } \\
\text { others }\end{array}$ & 2.74 & .864 & 2.73 & .829 & 2.85 & .816 & $2 / 535$ & .897 & .408 & .00 \\
\hline $\begin{array}{l}\text { CINIF6- Persuade } \\
\text { others to change } \\
\text { their minds }\end{array}$ & 2.66 & .909 & 2.41 & .792 & 2.57 & .852 & $2 / 534$ & $4.122 *$ & .017 & .02 \\
\hline
\end{tabular}

Parents' education/critical thinking. Analysis of Variance (ANOVA) examined significant differences in Parents' Education (independent variable) by means of the Critical Thinking CSXQ College Activity Items (dependent variables). This analysis yielded no significant differences with the CSXQ items (see Table 27). 
Table 27

Means, Standard Deviations, and One-Way Analysis of Variance for the Effects of Parents' Education on Critical Thinking CSXQ Variables

\begin{tabular}{|c|c|c|c|c|c|c|c|c|c|c|}
\hline \multirow[b]{2}{*}{ Variable } & \multicolumn{2}{|l|}{ No } & \multicolumn{2}{|c|}{$\begin{array}{l}\text { Yes, Both } \\
\text { Parents }\end{array}$} & \multicolumn{2}{|c|}{$\begin{array}{l}\text { Yes, One } \\
\text { Parent }\end{array}$} & \multirow[b]{2}{*}{$d f$} & \multirow[b]{2}{*}{$F$} & \multirow[b]{2}{*}{$p$} & \multirow[b]{2}{*}{$\eta^{2}$} \\
\hline & $M$ & $S D$ & $M$ & $S D$ & $M$ & $S D$ & & & & \\
\hline $\begin{array}{l}\text { CRSE5- Put together } \\
\text { different facts and } \\
\text { ideas }\end{array}$ & 2.95 & .837 & 2.96 & .748 & 2.91 & .815 & $2 / 527$ & .101 & .904 & 00 \\
\hline $\begin{array}{l}\text { CRSE8- Apply class } \\
\text { material to other } \\
\text { areas }\end{array}$ & 3.00 & 9.12 & 2.89 & .890 & 2.86 & .854 & $2 / 535$ & 1.386 & .251 & .01 \\
\hline $\begin{array}{l}\text { CRSE9- Use info } \\
\text { from other areas in } \\
\text { class }\end{array}$ & 2.93 & .896 & 2.88 & .820 & 3.03 & .883 & $2 / 534$ & 1.004 & .367 & .00 \\
\hline $\begin{array}{l}\text { CNINF2- Explore } \\
\text { different ways of } \\
\text { thinking }\end{array}$ & 2.91 & .922 & 2.76 & .795 & 2.83 & .792 & $2 / 523$ & 1.478 & .229 & .01 \\
\hline $\begin{array}{l}\text { CINIF5- Change } \\
\text { opinion because of } \\
\text { others }\end{array}$ & 2.40 & .819 & 2.32 & .753 & 2.38 & .779 & $2 / 535$ & .493 & .611 & .00 \\
\hline
\end{tabular}

Parents' education/cultural and social understanding. Analysis of Variance (ANOVA) examined significant differences in Parents' Education (independent variable) by means of the Cultural and Social Understanding CSXQ College Activity Items (dependent variables). This analysis yielded statistically significant differences (at least $p<.05$ ) with two CSXQ items (see Table 28). For the item "CAMRE2- Attend a concert or other music event", this ANOVA produced a significant overall finding $\mathrm{F}(2 / 538)=3.115, p<.05$. When the Tukey multiple comparison follow-up test was computed $(p=.068)$, it did not indicate significant difference in means but a strong trend between the groups of No $(M=1.87)$ and Yes, Both Parents 
$(M=2.09)$. This finding shows a strong trend that students who had both parents graduating from college more often expected to "attend a concert or other music event" than students who had no parents graduating from college.

For the item "STACQ3- Acquainted: students of diff race," the ANOVA produced a significant overall finding $\mathrm{F}(2 / 537)=3.360, p<.05$. When the Tukey multiple comparison follow-up test was computed $(p=.035)$, it indicated a significant difference in means between the groups of No $(M=3.25)$ and Yes, Both Parents $(M=3.23)$. This finding showed that students who had no parents graduating from college significantly more often expected to "make friends with students whose race or ethnic background is different" than students who had both parents graduating from college.

Table 28

Means, Standard Deviations, and One-Way Analysis of Variance for the Effects of Parents' Education on Cultural and Social Understanding CSXQ Variables

\begin{tabular}{|c|c|c|c|c|c|c|c|c|c|c|}
\hline \multirow[b]{2}{*}{ Variable } & \multicolumn{2}{|l|}{ No } & \multicolumn{2}{|c|}{$\begin{array}{l}\text { Yes, Both } \\
\text { Parents }\end{array}$} & \multicolumn{2}{|c|}{$\begin{array}{l}\text { Yes, One } \\
\text { Parent }\end{array}$} & \multirow[b]{2}{*}{$d f$} & \multirow[b]{2}{*}{$F$} & \multirow[b]{2}{*}{$p$} & \multirow[b]{2}{*}{$\eta^{2}$} \\
\hline & $M$ & $S D$ & $M$ & $S D$ & $M$ & $S D$ & & & & \\
\hline $\begin{array}{l}\text { CAMRE1- Go to exhibit- } \\
\text { gallery-performance }\end{array}$ & 1.75 & .925 & 1.90 & .973 & 1.84 & .861 & $2 / 539$ & 1.422 & .242 & .00 \\
\hline $\begin{array}{l}\text { CAMRE2- Attend a concert or } \\
\text { other music event }\end{array}$ & 1.87 & .924 & 2.09 & .984 & 2.07 & .984 & $2 / 538$ & $3.115^{*}$ & .045 & .01 \\
\hline $\begin{array}{l}\text { STACQ2- Acquainted: students } \\
\text { of diff background }\end{array}$ & 3.02 & .854 & 3.03 & .807 & 2.87 & .808 & $2 / 538$ & 1.554 & .212 & .01 \\
\hline $\begin{array}{l}\text { STACQ3- Acquainted: students } \\
\text { of diff race }\end{array}$ & 3.25 & .817 & 3.23 & .737 & 3.03 & .828 & $2 / 537$ & $3.360 *$ & .035 & .01 \\
\hline
\end{tabular}


Table 28 (continued)

Means, Standard Deviations, and One-Way Analysis of Variance for the Effects of Parents'

Education on Cultural and Social Understanding CSXQ Variables

\begin{tabular}{|c|c|c|c|c|c|c|c|c|c|c|}
\hline \multirow[b]{2}{*}{ Variable } & \multicolumn{2}{|l|}{ No } & \multicolumn{2}{|c|}{$\begin{array}{l}\text { Yes, Both } \\
\text { Parents }\end{array}$} & \multicolumn{2}{|c|}{$\begin{array}{l}\text { Yes, One } \\
\text { Parent }\end{array}$} & \multirow[b]{2}{*}{$d f$} & \multirow[b]{2}{*}{$F$} & \multirow[b]{2}{*}{$p$} & \multirow[b]{2}{*}{$\eta^{2}$} \\
\hline & $M$ & $S D$ & $M$ & $S D$ & $M$ & $S D$ & & & & \\
\hline $\begin{array}{l}\text { STACQ8- Discussions: } \\
\text { students of diff } \\
\text { religious }\end{array}$ & 2.55 & 1.102 & 2.37 & 1.003 & 2.43 & 1.009 & $2 / 538$ & 1.723 & .179 & .01 \\
\hline $\begin{array}{l}\text { STACQ7- Discussions: } \\
\text { students of diff political }\end{array}$ & 2.28 & 1.040 & 2.37 & .993 & 2.22 & .937 & $2 / 530$ & .809 & .446 & .00 \\
\hline $\begin{array}{l}\text { STACQ9- Discussions: } \\
\text { students of diff race }\end{array}$ & 2.58 & 1.070 & 2.51 & .997 & 2.50 & .995 & $2 / 528$ & .320 & .726 & .00 \\
\hline $\begin{array}{l}\text { CNTPS2- Topic: Social } \\
\text { issues--peace,justice, } \\
\text { etc. }\end{array}$ & 2.46 & .922 & 2.47 & .872 & 2.41 & .893 & $2 / 533$ & .179 & .836 & .00 \\
\hline $\begin{array}{l}\text { CNTPS3- Topic: } \\
\text { Different lifestyles, etc. }\end{array}$ & 2.55 & .881 & 2.60 & .904 & 2.66 & .901 & $2 / 529$ & .659 & .518 & .00 \\
\hline $\begin{array}{l}\text { CNTPS4- Topic: Ideas } \\
\text { of writers, etc. }\end{array}$ & 2.11 & .962 & 2.11 & .945 & 2.27 & .968 & $2 / 528$ & 1.203 & .301 & .00 \\
\hline $\begin{array}{l}\text { CNTPS5- Topic: The } \\
\text { arts--painting, poetry, } \\
\text { etc. }\end{array}$ & 2.34 & .976 & 2.31 & .994 & 2.37 & .956 & $2 / 532$ & .114 & .892 & .00 \\
\hline $\begin{array}{l}\text { CNPTS9- Topic: The } \\
\text { economy--employment, } \\
\text { etc. }\end{array}$ & 2.62 & .881 & 2.41 & .871 & 2.54 & .929 & $2 / 526$ & 2.823 & .060 & .01 \\
\hline $\begin{array}{l}\text { CNPTS10- Topic: } \\
\text { International relations }\end{array}$ & 2.36 & .955 & 2.37 & .947 & 2.36 & 1.021 & $2 / 530$ & .010 & .990 & .00 \\
\hline
\end{tabular}

Parents' education/quantitative reasoning. Analysis of Variance (ANOVA) examined significant differences in Parents' Education (independent variable) by means of the Quantitative Reasoning CSXQ College Activity Items (dependent variables). This analysis yielded no significant differences with the CSXQ items (see Table 29). 
Table 29

Means, Standard Deviations, and One-Way Analysis of Variance for the Effects of Parents' Education on Quantitative Reasoning CSXQ Variables

\begin{tabular}{|c|c|c|c|c|c|c|c|c|c|c|}
\hline \multirow[b]{2}{*}{ Variable } & \multicolumn{2}{|l|}{ No } & \multicolumn{2}{|c|}{$\begin{array}{l}\text { Yes, Both } \\
\text { Parents }\end{array}$} & \multicolumn{2}{|c|}{$\begin{array}{l}\text { Yes, One } \\
\text { Parent }\end{array}$} & \multirow[b]{2}{*}{$d f$} & \multirow[b]{2}{*}{$F$} & \multirow[b]{2}{*}{$p$} & \multirow[b]{2}{*}{$\eta^{2}$} \\
\hline & $M$ & $S D$ & $M$ & $S D$ & $M$ & $S D$ & & & & \\
\hline $\begin{array}{l}\text { SCI1- Memorize } \\
\text { formulas-definitions- } \\
\text { concepts }\end{array}$ & 2.80 & .894 & 2.91 & .893 & 2.92 & .955 & $2 / 528$ & 1.001 & .368 & .00 \\
\hline $\begin{array}{l}\text { SCI2- Express } \\
\text { relationships using } \\
\text { math terms }\end{array}$ & 2.43 & .978 & 2.59 & .999 & 2.51 & .99 & $2 / 528$ & 1.268 & .282 & .00 \\
\hline
\end{tabular}

Parents' education/scientific reasoning. Analysis of Variance (ANOVA) examined significant differences in Parents' Education (independent variable) by means of the Scientific Reasoning CSXQ College Activity Items (dependent variables) (see table 30). This Scientific Reasoning analysis yielded an overall statistically significant difference (at least $p<.05$ ) with one CSXQ item. For the item "SCI5- Complete an experiment with scientific methods," this ANOVA produced a significant overall finding $\mathrm{F}(2 / 538)=3.617, p<.05$ (see Table 30$)$. When the Tukey multiple comparison follow-up test was computed, it indicated a significant difference $(p=.020)$ between the groups of No $(M=2.20)$ and Yes, Both Parents (2.48). This finding showed that students who had both parents graduating from college significantly more often expected to "complete an experiment using scientific methods" than students who had no parents graduating from college. 
Table 30

Means, Standard Deviations, and One-Way Analysis of Variance for the Effects of Parents' Education on Scientific Reasoning CSXQ Variables

\begin{tabular}{|c|c|c|c|c|c|c|c|c|c|c|}
\hline \multirow[b]{2}{*}{ Variable } & \multicolumn{2}{|l|}{ No } & \multicolumn{2}{|c|}{$\begin{array}{l}\text { Yes, Both } \\
\text { Parents }\end{array}$} & \multicolumn{2}{|c|}{$\begin{array}{l}\text { Yes, One } \\
\text { Parent }\end{array}$} & \multirow[b]{2}{*}{$d f$} & \multirow[b]{2}{*}{$F$} & \multirow[b]{2}{*}{$p$} & \multirow[b]{2}{*}{$\eta^{2}$} \\
\hline & $M$ & $S D$ & $M$ & $S D$ & $M$ & $S D$ & & & & \\
\hline $\begin{array}{l}\text { SCI5- Complete } \\
\text { an experiment w- } \\
\text { sci methods }\end{array}$ & 2.20 & 1.038 & 2.48 & 1.031 & 2.30 & .930 & $2 / 538$ & $3.617^{*}$ & .028 & .01 \\
\hline $\begin{array}{l}\text { CNTPS6- Topic: } \\
\text { Science--theories, } \\
\text { etc. }\end{array}$ & 1.98 & .958 & 2.04 & .967 & 2.13 & .921 & $2 / 526$ & .964 & .382 & .00 \\
\hline $\begin{array}{l}\text { CNPTS8- Topic: } \\
\text { Social-ethical } \\
\text { issues re: science }\end{array}$ & 2.23 & .940 & 2.29 & .924 & 2.31 & .955 & $2 / 532$ & .321 & .725 & .00 \\
\hline
\end{tabular}

Parents' education/quantitative and scientific reasoning. Analysis of Variance (ANOVA) examined significant differences in Parents' Education (independent variable) by means of the Quantitative/Scientific Reasoning CSXQ College Activity Items (dependent variables) (see Table 31). This analysis yielded statistically significant differences (at least $p<$ .05) with the two CSXQ items (see Table 31). For the item "SCI3- Explain scientific concept to others," this ANOVA produced a significant overall finding $\mathrm{F}(2 / 526)=3.203, p<.05$. When the Tukey multiple comparison follow-up test was computed $(p=.039)$, it indicated significant differences in means between the groups of No $(M=2.25)$ and Yes, Both Parents $(M=2.49)$. This finding showed that students who had both parents graduating from college significantly more often expected to "explain understanding of scientific or mathematical theories, principles or concepts" than students who had no parents graduating from college. 
For the item "SCI4- Read articles about science not assigned," the ANOVA produced a significant overall finding $\mathrm{F}(2 / 528)=4.500, p<.05$. When the Tukey multiple comparison follow-up test was computed $(p=.033)$, it indicated a significant difference in means between the groups of No $(\mathrm{M}=1.96)$ and Yes, Both Parents $(\mathrm{M}=2.20)$. It also indicated a significant difference $(p=.044)$ between the groups of No $(M=1.96)$ and Yes, One Parent (2.23). This finding showed that students who had one or both parents graduating from college significantly more often expected to "read articles about scientific or mathematical theories or concepts in addition to those assigned for a class" than students who had no parents graduating from college. Table 31

Means, Standard Deviations, and One-Way Analysis of Variance for the Effects of Parents' Education on Quantitative/Scientific Reasoning CSXQ Variables

\begin{tabular}{|c|c|c|c|c|c|c|c|c|c|c|}
\hline \multirow[b]{2}{*}{ Variable } & \multicolumn{2}{|l|}{ No } & \multicolumn{2}{|c|}{$\begin{array}{l}\text { Yes, Both } \\
\text { Parents }\end{array}$} & \multicolumn{2}{|c|}{$\begin{array}{l}\text { Yes, One } \\
\text { Parent }\end{array}$} & \multirow[b]{2}{*}{$d f$} & \multirow[b]{2}{*}{$F$} & \multirow[b]{2}{*}{$p$} & \multirow[b]{2}{*}{$\eta^{2}$} \\
\hline & $M$ & $S D$ & $M$ & $S D$ & $M$ & $S D$ & & & & \\
\hline $\begin{array}{l}\text { SCI3- Explain } \\
\text { scientific concept to } \\
\text { others }\end{array}$ & 2.25 & .966 & 2.49 & .978 & 2.41 & .932 & $2 / 526$ & $3.203^{*}$ & .041 & .01 \\
\hline $\begin{array}{l}\text { SCI4- Read articles } \\
\text { about science not } \\
\text { assigned }\end{array}$ & 1.96 & .960 & 2.20 & .982 & 2.23 & .969 & $2 / 528$ & $4.500^{*}$ & .012 & .02 \\
\hline
\end{tabular}

\section{Research Question 2B: Employment}

This research question 2B looked for significant differences in the CSXQ General Education Variables by off campus employment. A one-way analysis of variance (ANOVA) was calculated to examine the effect of off-campus employment on student expectations of college. Data for the Employment variable were determined by the CSXQ item which asks how many hours do students work off-campus. Three groups were created based upon the students' 
responses. The first group was named "None" $(n=117)$. The next group was named "1-20 hours weekly" (n=192). The third group was named " 21 or more hours weekly" $(n=186)$. A statistically significant effect was found with two items in two general education clusters: Critical Thinking and Cultural and Social Understanding.

Employment and information literacy. Analysis of Variance (ANOVA) examined significant differences in Employment (independent variable) by means of the Information Literacy CSXQ College Activity Items (dependent variables). This analysis yielded no significant differences with the CSXQ items (see Table 32).

Table 32

Means, Standard Deviations, and One-Way Analysis of Variance for the Effects of Off-Campus Employment on Information Literacy CSXQ Variables

\begin{tabular}{|c|c|c|c|c|c|c|c|c|c|c|}
\hline \multirow[b]{2}{*}{ Variable } & \multicolumn{2}{|c|}{ None } & \multicolumn{2}{|c|}{$\begin{array}{l}\text { 1-20 Hrs } \\
\text { Weekly }\end{array}$} & \multicolumn{2}{|c|}{$\begin{array}{l}21 \text { or More Hrs } \\
\text { Weekly }\end{array}$} & \multirow[b]{2}{*}{$d f$} & \multirow[b]{2}{*}{$F$} & \multirow[b]{2}{*}{$p$} & \multirow[b]{2}{*}{$\eta^{2}$} \\
\hline & $M$ & $S D$ & $M$ & $S D$ & $M$ & $S D$ & & & & \\
\hline $\begin{array}{l}\text { LIBIT2- Use index or database } \\
\text { to find material }\end{array}$ & 2.66 & .990 & 2.77 & .976 & 2.77 & .987 & $2 / 485$ & .562 & .570 & .00 \\
\hline $\begin{array}{l}\text { LIBIT5- Use computer-word } \\
\text { processor for paper }\end{array}$ & 3.56 & .740 & 3.51 & .796 & 3.61 & .740 & $2 / 484$ & 697 & .498 & .00 \\
\hline $\begin{array}{l}\text { LIBIT8- Search internet for } \\
\text { course material }\end{array}$ & 3.40 & .747 & 3.37 & .842 & 3.37 & .873 & $2 / 482$ & .047 & .954 & .00 \\
\hline $\begin{array}{l}\text { CRSE11- Work on project } \\
\text { integrating ideas }\end{array}$ & 2.76 & .798 & 2.86 & .875 & 2.90 & .820 & $2 / 486$ & 1.083 & .340 & .00 \\
\hline $\begin{array}{l}\text { CNTPS7- Topic: Computers } \\
\text { and other technologies }\end{array}$ & 2.54 & .980 & 2.45 & .975 & 2.55 & .972 & $2 / 476$ & .599 & .550 & .00 \\
\hline
\end{tabular}

Employment and communication. Analysis of Variance (ANOVA) examined significant differences in Employment (independent variable) by means of the Communication CSXQ College Activity Items (dependent variables). This Communication analysis yielded no significant differences with the CSXQ items (see Table 33). 
Table 33

Means, Standard Deviations, and One-Way Analysis of Variance for the Effects of Off-Campus Employment on Communication CSXQ Variables

\begin{tabular}{|c|c|c|c|c|c|c|c|c|c|c|}
\hline \multirow[b]{2}{*}{ Variable } & \multicolumn{2}{|c|}{ None } & \multicolumn{2}{|c|}{$\begin{array}{l}\text { 1-20 Hrs } \\
\text { Weekly }\end{array}$} & \multicolumn{2}{|c|}{$\begin{array}{l}21 \text { or More } \\
\text { Hrs Weekly }\end{array}$} & \multirow[b]{2}{*}{$d f$} & \multirow[b]{2}{*}{$F$} & \multirow[b]{2}{*}{$p$} & \multirow[b]{2}{*}{$\eta^{2}$} \\
\hline & $M$ & $S D$ & $M$ & $S D$ & $M$ & $S D$ & & & & \\
\hline $\begin{array}{l}\text { CRSE3-Contribute } \\
\text { to class discussions }\end{array}$ & 2.72 & .850 & 2.84 & .844 & 2.85 & .818 & $2 / 486$ & .971 & .739 & .00 \\
\hline $\begin{array}{l}\text { CRSE6- Summarize } \\
\text { major points and } \\
\text { information }\end{array}$ & 2.86 & .851 & 2.87 & .833 & 2.80 & .890 & $2 / 481$ & .354 & .702 & .00 \\
\hline $\begin{array}{l}\text { CRSE10- Explain } \\
\text { course material to } \\
\text { others }\end{array}$ & 2.68 & .891 & 2.70 & .826 & 2.78 & .819 & $2 / 486$ & .719 & .488 & .00 \\
\hline $\begin{array}{l}\text { CINIF6- Persuade } \\
\text { others to change } \\
\text { their minds }\end{array}$ & 2.54 & .809 & 2.52 & .843 & 2.66 & .907 & $2 / 485$ & 1.550 & .213 & .00 \\
\hline
\end{tabular}

${ }^{*} \mathrm{p}<.05 . \eta^{2}$ is rounded.

Employment and critical thinking. Analysis of Variance (ANOVA) examined significant differences in Employment (independent variable) by means of the Critical Thinking CSXQ College Activity Items (dependent variables). This analysis yielded an overall statistically significant difference (at least $p<.05$ ) with one CSXQ item (see Table 34). For the item "CINIF5- Change opinion because of others," this ANOVA produced a significant overall finding $F(2 / 486)=3.336, p<.05$. When the Tukey multiple comparison follow-up test was computed ( $p=.027)$, it indicated the significant difference in means between the groups of " 1 to 20 Hours Weekly" $(M=2.28)$ and "21 or More Hours Weekly" $(M=2.49)$. This finding showed that students who worked 21 or more hours weekly (off campus) significantly more often expected to "change opinion as result of knowledge or arguments presented by others" than students who work 1 to 20 hours weekly (off campus). 
Table 34

Means, Standard Deviations, and One-Way Analysis of Variance for the Effects of Off-Campus Employment on Critical Thinking CSXQ Variables

\begin{tabular}{|c|c|c|c|c|c|c|c|c|c|c|}
\hline \multirow[b]{2}{*}{ Variable } & \multicolumn{2}{|c|}{ None } & \multicolumn{2}{|c|}{$\begin{array}{l}\text { 1-20 Hrs } \\
\text { Weekly }\end{array}$} & \multicolumn{2}{|c|}{$\begin{array}{l}21 \text { or More } \\
\text { Hrs Weekly }\end{array}$} & \multirow[b]{2}{*}{$d f$} & \multirow[b]{2}{*}{$F$} & \multirow[b]{2}{*}{$p$} & \multirow[b]{2}{*}{$\eta^{2}$} \\
\hline & $M$ & $S D$ & $M$ & $S D$ & $M$ & $S D$ & & & & \\
\hline $\begin{array}{l}\text { CRSE5- Put } \\
\text { together different } \\
\text { facts and ideas }\end{array}$ & 3.01 & .803 & 2.99 & .812 & 2.88 & .805 & $2 / 479$ & 1.188 & .306 & .00 \\
\hline $\begin{array}{l}\text { CRSE8- Apply } \\
\text { class material to } \\
\text { other areas }\end{array}$ & 2.83 & .927 & 2.97 & .890 & 2.95 & .890 & $2 / 487$ & .919 & .400 & .00 \\
\hline $\begin{array}{l}\text { CRSE9- Use info } \\
\text { from other areas in } \\
\text { class }\end{array}$ & 2.83 & .888 & 2.94 & .881 & 3.04 & .847 & $2 / 486$ & 1.976 & .140 & .00 \\
\hline $\begin{array}{l}\text { CNINF2- Explore } \\
\text { different ways of } \\
\text { thinking }\end{array}$ & 2.86 & .897 & 2.78 & .807 & 2.93 & .854 & $2 / 472$ & 1.363 & .257 & .00 \\
\hline $\begin{array}{l}\text { CINIF5- Change } \\
\text { opinion because of } \\
\text { others }\end{array}$ & 2.37 & .883 & 2.28 & .708 & 2.49 & .815 & $2 / 486$ & $3.336^{*}$ & .036 & .01 \\
\hline
\end{tabular}

Employment and cultural and social understanding. Analysis of Variance (ANOVA) examined significant differences in Employment (independent variable) by means of the Cultural and Social Understanding CSXQ College Activity Items (dependent variables) (see Table 35). This Cultural and Social Understanding analysis yielded an overall statistically significant difference (at least $p<.05$ ) with the one CSXQ item. For the item, "CNTPS2- Topic: Social issues--peace, justice, etc.," this ANOVA produced a significant overall finding F(2/282)= 4.284, $p<.05$. When the Tukey multiple comparison follow-up test was computed $(p=.029)$, it indicated a significant differences in means between the groups of None $(\mathrm{M}=2.34)$ and "21 or 
More Hours Weekly" (M=2.60); a significant difference in means $(p=.044)$ between "1-20 Hours

Weekly" $(M=2.39)$ and "21 or More Hours Weekly" $(M=2.60)$. This finding showed that

students who work 21 or more hours weekly (off campus) significantly more often expected to discuss "social issues such as peace, justice, human rights, equality, and race relations" than students who do not work off campus. This finding also showed that students who work 21 or more hours weekly (off campus) significantly more often expected to discuss social issues than students who work 1 to 20 hours weekly (off campus).

Table 35

Means, Standard Deviations, and One-Way Analysis of Variance for the Effects of Off-Campus Employment on Cultural and Social CSXQ Variables

\begin{tabular}{|c|c|c|c|c|c|c|c|c|c|c|}
\hline \multirow[b]{2}{*}{ Variable } & \multicolumn{2}{|c|}{ None } & \multicolumn{2}{|c|}{$\begin{array}{l}\text { 1-20 Hrs } \\
\text { Weekly }\end{array}$} & \multicolumn{2}{|c|}{$\begin{array}{l}21 \text { or More Hrs } \\
\text { Weekly }\end{array}$} & \multirow[b]{2}{*}{$d f$} & \multirow[b]{2}{*}{$F$} & \multirow[b]{2}{*}{$p$} & \multirow[b]{2}{*}{$\eta^{2}$} \\
\hline & $M$ & $S D$ & $M$ & $S D$ & $M$ & $S D$ & & & & \\
\hline $\begin{array}{l}\text { CAMRE1- Go to exhibit- } \\
\text { gallery-performance }\end{array}$ & 1.84 & .938 & 1.85 & .885 & 1.78 & .936 & $2 / 487$ & .297 & .743 & .00 \\
\hline $\begin{array}{l}\text { CAMRE2- Attend a concert or } \\
\text { other music event }\end{array}$ & 1.92 & .970 & 2.01 & .951 & 1.96 & .977 & $2 / 486$ & .282 & .754 & .00 \\
\hline $\begin{array}{l}\text { STACQ2- Acquainted: } \\
\text { students of diff background }\end{array}$ & 2.95 & .853 & 2.95 & .807 & 3.05 & .824 & $2 / 488$ & .902 & .407 & .00 \\
\hline $\begin{array}{l}\text { STACQ3- Acquainted: } \\
\text { students of diff race }\end{array}$ & 3.16 & .830 & 3.17 & .782 & 3.23 & .784 & $2 / 486$ & .421 & .656 & .00 \\
\hline $\begin{array}{l}\text { STACQ6- Discussions: } \\
\text { students of diff values }\end{array}$ & 2.62 & .962 & 2.75 & .895 & 2.74 & .974 & $2 / 490$ & .772 & .462 & .00 \\
\hline
\end{tabular}


Table 35 (continued)

Means, Standard Deviations, and One-Way Analysis of Variance for the Effects of Off-Campus Employment on Cultural and Social CSXQ Variables

\begin{tabular}{|c|c|c|c|c|c|c|c|c|c|c|}
\hline \multirow[b]{2}{*}{ Variable } & \multicolumn{2}{|l|}{ None } & \multicolumn{2}{|c|}{$\begin{array}{l}\text { 1-20 Hrs } \\
\text { Weekly }\end{array}$} & \multicolumn{2}{|c|}{$\begin{array}{l}21 \text { or More Hrs } \\
\text { Weekly }\end{array}$} & \multirow[b]{2}{*}{$d f$} & \multirow[b]{2}{*}{$F$} & \multirow[b]{2}{*}{$p$} & \multirow[b]{2}{*}{$\eta^{2}$} \\
\hline & $M$ & $S D$ & $M$ & $S D$ & $M$ & $S D$ & & & & \\
\hline $\begin{array}{l}\text { STACQ8- } \\
\text { Discussions: students } \\
\text { of diff religious }\end{array}$ & 2.31 & 1.029 & 2.51 & .993 & 2.52 & 1.097 & $2 / 489$ & 1.761 & .173 & .01 \\
\hline $\begin{array}{l}\text { STACQ7- } \\
\text { Discussions: students } \\
\text { of diff political }\end{array}$ & 2.21 & 964 & 2.33 & .983 & 2.34 & 1.020 & $2 / 477$ & .722 & .486 & .00 \\
\hline $\begin{array}{l}\text { STACQ9- } \\
\text { Discussions: students } \\
\text { of diff race }\end{array}$ & 2.53 & .993 & 2.56 & .955 & 2.62 & 1.077 & $2 / 477$ & .349 & .706 & .00 \\
\hline $\begin{array}{l}\text { CNTPS2- Topic: } \\
\text { Social issues-- } \\
\text { peace,justice, etc. }\end{array}$ & 2.34 & .841 & 2.39 & .868 & 2.60 & .874 & $2 / 482$ & $4.284 *$ & .014 & .02 \\
\hline $\begin{array}{l}\text { CNTPS3- Topic: } \\
\text { Different lifestyles, } \\
\text { etc. }\end{array}$ & 2.46 & .869 & 2.59 & .867 & 2.69 & .906 & $2 / 478$ & 2.432 & .089 & .01 \\
\hline $\begin{array}{l}\text { CNTPS4- Topic: Ideas } \\
\text { of writers, etc. }\end{array}$ & 2.15 & .941 & 2.10 & .948 & 2.15 & .950 & $2 / 477$ & .130 & .878 & .00 \\
\hline $\begin{array}{l}\text { CNTPS5- Topic: The } \\
\text { arts--painting, poetry, } \\
\text { etc. }\end{array}$ & 2.46 & 1.012 & 2.28 & .922 & 2.32 & 1.011 & $2 / 479$ & 1.122 & .327 & .00 \\
\hline $\begin{array}{l}\text { CNPTS9- Topic: The } \\
\text { economy-- } \\
\text { employment, etc. }\end{array}$ & 2.47 & .880 & 2.51 & .910 & 2.62 & .852 & $2 / 475$ & 1.165 & .313 & .00 \\
\hline $\begin{array}{l}\text { CNPTS10- Topic: } \\
\text { International relations }\end{array}$ & 2.30 & .870 & 2.36 & .959 & 2.45 & .991 & $2 / 479$ & 981 & .376 & .00 \\
\hline
\end{tabular}

Employment and quantitative reasoning. Analysis of Variance (ANOVA) examined significant differences in Employment (independent variable) by means of the Quantitative Reasoning CSXQ College Activity Items (dependent variables). This analysis yielded no significant differences with the two CSXQ items (see Table 36). 
Table 36

Means, Standard Deviations, and One-Way Analysis of Variance for the Effects of Off-Campus Employment on Quantitative Reasoning CSXQ Variables

\begin{tabular}{|c|c|c|c|c|c|c|c|c|c|c|}
\hline \multirow[b]{2}{*}{ Variable } & \multicolumn{2}{|c|}{ None } & \multicolumn{2}{|c|}{$\begin{array}{l}\text { 1-20 Hrs } \\
\text { Weekly }\end{array}$} & \multicolumn{2}{|c|}{$\begin{array}{l}21 \text { or More } \\
\text { Hrs Weekly }\end{array}$} & \multirow[b]{2}{*}{$d f$} & \multirow[b]{2}{*}{$F$} & \multirow[b]{2}{*}{$p$} & \multirow[b]{2}{*}{$\eta^{2}$} \\
\hline & $M$ & $S D$ & $M$ & $S D$ & $M$ & $S D$ & & & & \\
\hline $\begin{array}{l}\text { SCI1- Memorize } \\
\text { formulas- } \\
\text { definitions-concepts }\end{array}$ & 2.90 & .870 & 2.90 & .886 & 2.81 & .928 & $2 / 476$ & .576 & .562 & .00 \\
\hline $\begin{array}{l}\text { SCI2- Express } \\
\text { relationships using } \\
\text { math terms }\end{array}$ & 2.52 & .900 & 2.49 & 1.018 & 2.56 & .983 & $2 / 476$ & .189 & .828 & .00 \\
\hline
\end{tabular}

Employment and scientific reasoning. Analysis of Variance (ANOVA) examined significant differences in Employment (independent variable) by means of the Scientific Reasoning CSXQ College Activity Items (dependent variables). This analysis yielded no significant differences with the three CSXQ items (see Table 37).

Table 37

Means, Standard Deviations, and One-Way Analysis of Variance for the Effects of Off-Campus Employment on Scientific Reasoning CSXQ Variables

\begin{tabular}{|c|c|c|c|c|c|c|c|c|c|c|}
\hline \multirow[b]{2}{*}{ Variable } & \multicolumn{2}{|c|}{ None } & \multicolumn{2}{|c|}{$\begin{array}{l}\text { 1-20 Hrs } \\
\text { Weekly }\end{array}$} & \multicolumn{2}{|c|}{$\begin{array}{l}21 \text { or More } \\
\text { Hrs Weekly }\end{array}$} & \multirow[b]{2}{*}{$d f$} & \multirow[b]{2}{*}{$F$} & \multirow[b]{2}{*}{$p$} & \multirow[b]{2}{*}{$\eta^{2}$} \\
\hline & $M$ & $S D$ & $M$ & $S D$ & $M$ & $S D$ & & & & \\
\hline $\begin{array}{l}\text { SCI5- Complete } \\
\text { an experiment w- } \\
\text { sci methods }\end{array}$ & 2.15 & .903 & 2.43 & 1.040 & 2.29 & 1.041 & $2 / 476$ & 2.725 & .067 & .01 \\
\hline $\begin{array}{l}\text { CNTPS6- Topic: } \\
\text { Science--theories, } \\
\text { etc. }\end{array}$ & 2.15 & .988 & 1.99 & .953 & 1.99 & .904 & $2 / 476$ & 1.236 & .292 & .00 \\
\hline $\begin{array}{l}\text { CNPTS8- Topic: } \\
\text { Social-ethical } \\
\text { issues re: science }\end{array}$ & 2.21 & .934 & 2.23 & .925 & 2.33 & .908 & $2 / 476$ & .786 & .456 & .00 \\
\hline
\end{tabular}
$* p<.05 . \eta^{2}$ is rounded. 
Employment/quantitative and scientific reasoning. Analysis of Variance (ANOVA)

examined significant differences in Employment (independent variable) by means of the

Scientific and Quantitative Reasoning CSXQ College Activity Items (dependent variables). This

analysis yielded no significant differences with the two CSXQ items (see Table 38).

Table 38

Means, Standard Deviations, and One-Way Analysis of Variance for the Effects of Off-Campus

Employment on Quantitative/Scientific Reasoning CSXQ Variables

\begin{tabular}{|c|c|c|c|c|c|c|c|c|c|c|}
\hline \multirow[b]{2}{*}{ Variable } & \multicolumn{2}{|c|}{ None } & \multicolumn{2}{|c|}{$\begin{array}{l}\text { 1-20 Hrs } \\
\text { Weekly }\end{array}$} & \multicolumn{2}{|c|}{$\begin{array}{l}21 \text { or More Hrs } \\
\text { Weekly }\end{array}$} & \multirow[b]{2}{*}{$d f$} & \multirow[b]{2}{*}{$F$} & \multirow[b]{2}{*}{$p$} & \multirow[b]{2}{*}{$\eta^{2}$} \\
\hline & $M$ & $S D$ & $M$ & $S D$ & $M$ & $S D$ & & & & \\
\hline $\begin{array}{l}\text { SCI3- Explain } \\
\text { scientific concept } \\
\text { to others }\end{array}$ & 2.37 & .949 & 2.35 & .897 & 2.37 & 1.002 & $2 / 474$ & .021 & .979 & .00 \\
\hline $\begin{array}{l}\text { SCI4- Read articles } \\
\text { about science not } \\
\text { assigned }\end{array}$ & 2.05 & 2.11 & 2.11 & .963 & 2.14 & 1.010 & $2 / 475$ & .295 & .745 & .00 \\
\hline
\end{tabular}

\section{Research Question 2C: College Opinion}

This research question $2 \mathrm{C}$ looked for significant differences in the CSXQ General Education Variables based upon students' opinion of college. A one-way analysis of variance (ANOVA) was calculated to examine the effect of College Opinion on student expectations of college. Data for the College Opinion variable were derived from the CSXQ item which asks whether students believe they will like college. Three groups were created based upon the students' responses: Not Like/Neutral $(n=173)$, Like $(n=294)$, and Enthusiastic $(n=165)$. A statistically significant effect was found with 32 items in all seven general education clusters.

College opinion/information literacy. Analysis of Variance (ANOVA) examined significant differences in College Opinion (independent variable) by means of the Information 
Literacy CSXQ College Activity Items (dependent variables). The analysis yielded statistically significant differences (at least $p<.05$ ) with four CSXQ items (see Table 39). For the item "LIBIT2- Use index or database to find material," this ANOVA produced a significant overall finding $\mathrm{F}(2 / 621)=5.803, p<.05$. When the Tukey multiple comparison follow-up test was computed ( $p=.007)$, it indicated the significant difference in means between the groups of Not Like/Neutral ( $M=2.54)$ and Enthusiastic $(M=2.85)$. The Tukey test also found a significant difference $(p=.008)$ between the groups of Not Like/Neutral $(\mathrm{M}=2.54)$ and Like $(\mathrm{M}=2.81)$. This finding showed that students who were enthusiastic about college significantly more often expected to "use an index or database (computer, card catalog, etc.) to find material on some topic" than students who were neutral or did not like college. This finding also showed that students who liked college significantly more often expected to "use an index or database (computer, card catalog, etc.) to find material on some topic" than students who were neutral or did not like college.

For the item "LIBIT5- Use computer-word processor for paper," this ANOVA produced a significant overall finding $\mathrm{F}(2 / 620)=4.001, p<.05$. When the Tukey multiple comparison follow-up test was computed, it indicated a significant difference $(p=.013)$ between the groups of Like (M=3.64) and Not Like/Neutral (3.43). This finding showed that students who liked college significantly more often expected to "use a computer or word processor to prepare reports or papers" than students who were neutral or did not like college.

For the item "CRSE11- Work on project integrating ideas," this ANOVA produced a significant overall finding $\mathrm{F}(2 / 622)=11.281, p<.05$. When the Tukey multiple comparison follow-up test was computed $(p=.000)$, it indicated the significant difference in means between the groups of Not Like/Neutral $(\mathrm{M}=2.60)$ and Enthusiastic $(\mathrm{M}=3.02)$. The Tukey test also 
found a significant difference $(p=.004)$ between the groups of Not Like/Neutral $(\mathrm{M}=2.60)$ and Like ( $\mathrm{M}=2.86)$. This finding showed that students who were enthusiastic about college significantly more often expected to "prepare a paper or project where you had to integrate ideas from various sources" than students who were neutral or did not like college. This finding also showed that students who liked college more often expected to "prepare a paper or project where you had to integrate ideas from various sources" than students who were neutral or did not like college.

For the item "CNTPS7- Topic: Computers and other technologies", this ANOVA produced a significant overall finding $\mathrm{F}(2 / 611)=9.989, p<.05$. When the Tukey multiple comparison follow-up test was computed $(p=.000)$, it indicated the significant difference in means between the groups of Not Like/Neutral $(M=2.35)$ and Enthusiastic $(M=2.80)$. The Tukey test also found a significant difference $(p=.001)$ between the groups of Like $(\mathrm{M}=2.45)$ and Enthusiastic $(M=2.80)$. This finding showed that students who were enthusiastic about college significantly more often expected to "discuss computers or other technologies" than students who were neutral or did not like college. This finding showed that students who were enthusiastic about college significantly more often expected to "discuss computers or other technologies" than students who liked college. 
Table 39

Means, Standard Deviations, and One-Way Analysis of Variance for the Effects of College Opinion on Information Literacy CSXQ Variables

\begin{tabular}{|c|c|c|c|c|c|c|c|c|c|c|}
\hline \multirow[b]{2}{*}{ Variable } & \multicolumn{2}{|c|}{$\begin{array}{l}\text { Not } \\
\text { Like/Neutral }\end{array}$} & \multicolumn{2}{|l|}{ Like } & \multicolumn{2}{|c|}{ Enthusiastic } & \multirow[b]{2}{*}{$d f$} & \multirow[b]{2}{*}{$F$} & \multirow[b]{2}{*}{$p$} & \multirow[b]{2}{*}{$\eta^{2}$} \\
\hline & $M$ & $S D$ & $M$ & $S D$ & $M$ & $S D$ & & & & \\
\hline $\begin{array}{l}\text { LIBIT2- Use } \\
\text { index or database } \\
\text { to find material }\end{array}$ & 2.54 & .980 & 2.81 & .945 & 2.85 & .980 & $2 / 621$ & $5.803 *$ & .003 & .02 \\
\hline $\begin{array}{l}\text { LIBIT5- Use } \\
\text { computer-word } \\
\text { processor for } \\
\text { paper }\end{array}$ & 3.43 & .841 & 3.64 & .684 & 3.57 & .792 & $2 / 620$ & $4.001 *$ & .019 & .01 \\
\hline $\begin{array}{l}\text { LIBIT8- Search } \\
\text { internet for course } \\
\text { material }\end{array}$ & 3.28 & .894 & 3.33 & .859 & 3.47 & .811 & $2 / 617$ & 2.078 & .126 & .00 \\
\hline $\begin{array}{l}\text { CRSE11- Work on } \\
\text { project integrating } \\
\text { ideas }\end{array}$ & 2.60 & .810 & 2.86 & .819 & 3.02 & .855 & $2 / 622$ & $11.281^{*}$ & .000 & .04 \\
\hline $\begin{array}{l}\text { CNTPS7- Topic: } \\
\text { Computers and } \\
\text { other technologies }\end{array}$ & 2.35 & .965 & 2.45 & .965 & 2.80 & .969 & $2 / 611$ & $9.989 *$ & .000 & .03 \\
\hline
\end{tabular}

College opinion/communication. Analysis of Variance (ANOVA) examined significant differences in College Opinion (independent variable) by means of the Communication CSXQ College Activity Items (dependent variables). This analysis yielded statistically significant differences (at least $p<.05$ ) with the three CSXQ items (see Table 40). For the item "CRSE3Contribute to class discussions," this ANOVA produced a significant overall finding $F(2 / 620)=$ $17.754, p<.05$. When the Tukey multiple comparison follow-up test was computed $(p=.018)$, it indicated a significant difference in means between the groups of Not Like/Neutral $(\mathrm{M}=2.58)$ and Like $(M=2.80)$; a significant difference in means $(p=.000)$ between the groups Not 
Like/Neutral $(\mathrm{M}=2.58)$ and Enthusiastic $(\mathrm{M}=3.10)$; and a significant difference in the means $(p=.000)$ between the groups Like $(\mathrm{M}=2.80)$ and Enthusiastic $(\mathrm{M}=3.10)$. This finding showed that students who were enthusiastic about college significantly more often expected to "contribute to class discussions" than students who liked college and students who were neutral or did not like college. This finding also showed that students who liked college significantly more often expected to "contribute to class discussions" than students who were neutral or did not like college.

For the item "CRSE6- Summarize major points and information," this ANOVA produced a significant overall finding $\mathrm{F}(2 / 615)=17.162, p<.05$. When the Tukey multiple comparison follow-up test was computed $(p=.018)$, it indicated significant differences in means between the groups of Not Like/Neutral $(\mathrm{M}=2.56)$ and Like $(\mathrm{M}=2.83)$; a significant difference $(p=.000)$ in means between Not Like/Neutral $(\mathrm{M}=2.56)$ and Enthusiastic $(\mathrm{M}=3.10)$; and a significant difference in means $(p=.000)$ between Like $(\mathrm{M}=2.83)$ and Enthusiastic $(\mathrm{M}=3.10)$. This finding showed that students who were enthusiastic about college significantly more often expected to "summarize major points and information from readings or class notes" than students who liked college and students who were neutral or did not like college. This finding also showed that students who liked college significantly more often expected to "summarize major points and information from readings and class notes" than students who were neutral or did not like college.

For the item "CRSE10- Explain course material to others," this ANOVA produced a significant overall finding $\mathrm{F}(2 / 623)=12.715, p<.05$. When the Tukey multiple comparison follow-up test was computed ( $p=.004)$, it indicated a significant differences in means between the groups of Not Like/Neutral $(\mathrm{M}=2.49)$ and Like $(\mathrm{M}=2.76)$; a significant difference in means 
$(p=.000)$ between Not Like/Neutral $(\mathrm{M}=2.49)$ and Enthusiastic $(\mathrm{M}=2.95)$; and a significant difference in means $(p=.000)$ between Like $(M=2.76)$ and Enthusiastic $(M=2.95)$. This finding showed that students who were enthusiastic about college significantly more often expected to “explain material from course to someone else (another student, friend, co-worker, family member)" than students who liked college and students who were neutral or did not like college. This finding also showed that students who liked college significantly more often expected to “explain material from course to someone else (another student, friend, co-worker, family member)" than students who were neutral or did not like college.

Table 40

Means, Standard Deviations, and One-Way Analyses of Variance for the Effects of College Opinion on Communication CSXQ Variables

\begin{tabular}{|c|c|c|c|c|c|c|c|c|c|c|}
\hline \multirow[b]{2}{*}{ Variable } & \multicolumn{2}{|c|}{$\begin{array}{l}\text { Not } \\
\text { Like/Neutral }\end{array}$} & \multicolumn{2}{|l|}{ Like } & \multicolumn{2}{|c|}{ Enthusiastic } & \multirow[b]{2}{*}{$d f$} & \multirow[b]{2}{*}{$F$} & \multirow[b]{2}{*}{$p$} & \multirow[b]{2}{*}{$\eta^{2}$} \\
\hline & $M$ & $S D$ & $M$ & $S D$ & $M$ & $S D$ & & & & \\
\hline $\begin{array}{l}\text { CRSE3-Contribute to class } \\
\text { discussions }\end{array}$ & 2.58 & .804 & 2.80 & .803 & 3.10 & .809 & $2 / 620$ & $17.754 *$ & .000 & .05 \\
\hline $\begin{array}{l}\text { CRSE6- Summarize major } \\
\text { points and information }\end{array}$ & 2.56 & .809 & 2.83 & .872 & 3.10 & .836 & $2 / 615$ & $17.162 *$ & .000 & .05 \\
\hline $\begin{array}{l}\text { CRSE10- Explain course } \\
\text { material to others }\end{array}$ & 2.49 & .858 & 2.76 & .829 & 2.95 & .825 & $2 / 623$ & $12.715^{*}$ & .000 & .04 \\
\hline $\begin{array}{l}\text { CINIF6- Persuade others to } \\
\text { change their minds }\end{array}$ & 2.51 & .844 & 2.56 & .856 & 2.64 & .889 & $2 / 622$ & 1.043 & .353 & .00 \\
\hline
\end{tabular}

College opinion and critical thinking. Analysis of Variance (ANOVA) examined significant differences in College Opinion (independent variable) by means of the Critical Thinking CSXQ College Activity Items (dependent variables). This analysis yielded statistically significant differences (at least $p<.05$ ) with all five CSXQ items (see Table 41). For the item “CRSE5- Put together different facts and ideas," this ANOVA produced a significant overall finding $\mathrm{F}(2 / 616)=13.375, p<.05$. When the Tukey multiple comparison follow-up test was 
computed ( $p=.001)$, it indicated significant difference in means between the groups of Not Like/Neutral ( $\mathrm{M}=2.68)$ and Like $(\mathrm{M}=2.94)$; a significant difference $(p=.000)$ between the groups of Not Like/Neutral $(\mathrm{M}=2.68)$ and Enthusiastic $(\mathrm{M}=3.19)$; and a significant difference $(p=.005)$ between the groups of Like $(M=2.94)$ and Enthusiastic $(M=3.19)$. This finding showed that students who were enthusiastic about college significantly more often expected to "try to see how different facts and ideas fit together" than students who liked college and students who were neutral or did not like college. This finding also showed that students who liked college significantly more often expected to "try to see how different facts and ideas fit together" than students who were neutral or did not like college.

For the item "CRSE8- Apply class material to other areas," this ANOVA produced a significant overall finding $\mathrm{F}(2 / 623)=21.234, p<.05$. When the Tukey multiple comparison follow-up test was computed ( $p=.005)$, it indicated significant difference in means between the groups of Not Like/Neutral $(\mathrm{M}=2.62)$ and Like $(\mathrm{M}=2.89)$; a significant difference $(p=.000)$ between the groups of Not Like/Neutral $(\mathrm{M}=2.62)$ and Enthusiastic $(\mathrm{M}=3.24)$; and a significant difference $(p=.000)$ between the groups of Like $(\mathrm{M}=2.89)$ and Enthusiastic $(\mathrm{M}=3.24)$. This finding showed that students who were enthusiastic about college significantly more often expected to "apply material learned in class to other areas (a job or internship, other courses, relationships with friends, family, co-workers, etc.)" than students who liked college and students who were neutral or did not like college. This finding also showed that students who liked college significantly more often expected to "apply material learned in class to other areas (a job or internship, other courses, relationships with friends, family, co-workers, etc.)" than students who were neutral or did not like college. 
For the item "CRSE9- Use info from other areas in class," this ANOVA produced a significant overall finding $\mathrm{F}(2 / 623)=13.890, p<.05$. When the Tukey multiple comparison follow-up test was computed $(p=.009)$, it indicated significant difference in means between the groups of Not Like/Neutral $(\mathrm{M}=2.66)$ and Like $(\mathrm{M}=2.91)$; a significant difference $(p=.000)$ between the groups of Not Like/Neutral $(\mathrm{M}=2.66)$ and Enthusiastic $(\mathrm{M}=3.16)$; and a significant difference $(p=.009)$ between the groups of Like $(\mathrm{M}=2.91)$ and Enthusiastic $(\mathrm{M}=3.16)$. This finding showed that students who were enthusiastic about college significantly more often expected to "use information or experience from other areas of life (job, internship, interactions with others) in class discussions or assignments" than students who liked college and students who were neutral or did not like college. This finding also showed that students who liked college significantly more often expected to "use information or experience from other areas of life (job, internship, interactions with others) in class discussions or assignments" than students who were neutral or did not like college.

For the item "CNINF2- Explore different ways of thinking," this ANOVA produced a significant overall finding $\mathrm{F}(2 / 606)=16.112, p<.05$. When the Tukey multiple comparison follow-up test was computed ( $p=.000)$, it indicated significant difference in means between the groups of Not Like/Neutral (M=2.62) and Enthusiastic $(\mathrm{M}=3.14)$; and a significant difference $(p=.000)$ between the groups of Like $(\mathrm{M}=2.81)$ and Enthusiastic $(\mathrm{M}=3.14)$. This finding showed that students who were enthusiastic about college significantly more often expected to "explore different ways of thinking about an issue" than students who liked college and students who were neutral or did not like college.

For the item "CINIF5- Change opinion because of others" this ANOVA produced a significant overall finding $\mathrm{F}(2 / 623)=3.397, p<.05$. The Tukey multiple comparison follow-up 
test did not identify significant differences but a strong trend $(p=.061)$ between the groups of Not Like/Neutral $(M=2.24)$ and Like $(M=2.41)$; and a strong trend $(p=.053)$ between the groups of Not Like/Neutral $(\mathrm{M}=2.24)$ and Enthusiastic $(\mathrm{M}=2.44)$. This finding shows a strong trend that students who were enthusiastic about college more often expected to "change opinion as result of knowledge or arguments presented by others" than students who liked college and students who were neutral or did not like college. This finding also shows a strong trend that students who liked college more often expected to "change opinion as result of knowledge or arguments presented by others" than students who were neutral or did not like college.

Table 41

Means, Standard Deviations, and One-Way Analysis of Variance for the Effects of College Opinion on Critical Thinking CSXQ Variables

\begin{tabular}{|c|c|c|c|c|c|c|c|c|c|c|}
\hline \multirow[b]{2}{*}{ Variable } & \multicolumn{2}{|c|}{$\begin{array}{l}\text { Not } \\
\text { Like/Neutral }\end{array}$} & \multicolumn{2}{|l|}{ Like } & \multicolumn{2}{|c|}{ Enthusiastic } & \multirow[b]{2}{*}{$d f$} & \multirow[b]{2}{*}{$F$} & \multirow[b]{2}{*}{$p$} & \multirow[b]{2}{*}{$\eta^{2}$} \\
\hline & $M$ & $S D$ & $M$ & $S D$ & $M$ & $S D$ & & & & \\
\hline $\begin{array}{l}\text { CRSE5- Put together different } \\
\text { facts and ideas }\end{array}$ & 2.68 & .826 & 2.94 & .757 & 3.19 & .802 & $2 / 616$ & $13.375^{*}$ & .000 & .05 \\
\hline $\begin{array}{l}\text { CRSE8- Apply class material } \\
\text { to other areas }\end{array}$ & 2.62 & .957 & 2.89 & .863 & 3.24 & .844 & $2 / 623$ & $21.234^{*}$ & .000 & .06 \\
\hline $\begin{array}{l}\text { CRSE9- Use info from other } \\
\text { areas in class }\end{array}$ & 2.66 & .902 & 2.91 & .841 & 3.16 & .862 & $2 / 623$ & $13.890^{*}$ & .000 & .04 \\
\hline $\begin{array}{l}\text { CNINF2- Explore different } \\
\text { ways of thinking }\end{array}$ & 2.62 & .880 & 2.81 & .844 & 3.14 & .773 & $2 / 606$ & $16.112^{*}$ & .000 & .05 \\
\hline $\begin{array}{l}\text { CINIF5- Change opinion } \\
\text { because of others }\end{array}$ & 2.24 & .796 & 2.41 & .792 & 2.44 & .763 & $2 / 623$ & $3.397^{*}$ & .034 & .01 \\
\hline
\end{tabular}

College opinion and cultural and social understanding. Analysis of Variance (ANOVA) examined significant differences in College Opinion (independent variable) by means of the Cultural and Social Understanding CSXQ College Activity Items (dependent variables). This analysis yielded statistically significant differences (at least $p<.05$ ) with 13 CSXQ items 
(see Table 42). For the item, "CAMRE1- Go to exhibit-gallery-performance," this ANOVA produced a significant overall finding $\mathrm{F}(2 / 623)=6.437, p<.05$. When the Tukey multiple comparison follow-up test was computed $(p=.001)$, it indicated a significant difference in means between the groups of Not Like/Neutral $(M=1.66)$ and Enthusiastic $(M=2.02)$. This finding showed that students who were enthusiastic about college significantly more often expected to "go to an art exhibit/gallery or a play, dance, or other theater performance, on or off campus" than students who were neutral or did not like college.

For the item "STACQ2- Acquainted: students of diff background," this ANOVA produced a significant overall finding $\mathrm{F}(2 / 624)=14.605, p<.05$. When the Tukey multiple comparison follow-up test was computed $(p=.000)$, it indicated significant difference in means between the groups of Not like/Neutral $(M=2.78)$ and Enthusiastic $(M=3.25)$; and a significant difference $(p=.000)$ between the groups of Like $(M=2.92)$ and Enthusiastic $(M=3.25)$. This finding showed that students who were enthusiastic about college significantly more often expected to "make friends with students whose family background (economic, social) is different" than students who liked college and students who were neutral or did not like college.

For the item "STACQ3- Acquainted: students of diff race," this ANOVA produced a significant overall finding $\mathrm{F}(2 / 624)=12.847, p<.05$. When the Tukey multiple comparison follow-up test was computed $(p=.000)$, it indicated significant difference in means between the groups of Not like/Neutral $(\mathrm{M}=3.02)$ and Enthusiastic $(\mathrm{M}=3.44)$; and a significant difference $(p=.000)$ between the groups of Like $(\mathrm{M}=3.11)$ and Enthusiastic $(\mathrm{M}=3.44)$. This finding showed that students who were enthusiastic about college significantly more often expected to "make friends with students whose race or ethnic background is different" than students who liked college and students who were neutral or did not like college. 
For the item, "STACQ6- Discussions: students of diff values", this ANOVA produced a significant overall finding $\mathrm{F}(2 / 626)=13.329, p<.05$. When the Tukey multiple comparison follow-up test was computed $(p=.000)$, it indicated significant difference in means between the groups of Not like/Neutral $(\mathrm{M}=2.45)$ and Enthusiastic $(\mathrm{M}=2.96)$; and a significant difference $(p=.001)$ between the groups of Like $(M=2.63)$ and Enthusiastic $(M=2.96)$. This finding showed that students who were enthusiastic about college significantly more often expected to "have serious discussions with students whose philosophy of life or personal values are very different" than students who liked college and students who were neutral or did not like college.

For the item "STACQ8- Discussions: students of diff religious," this ANOVA produced a significant overall finding $\mathrm{F}(2 / 625)=7.546, p<.05$. When the Tukey multiple comparison follow-up test was computed $(p=.000)$, it indicated significant difference in means between the groups of Not like/Neutral $(\mathrm{M}=2.25)$ and Enthusiastic $(\mathrm{M}=2.68)$; and a significant difference $(p=.013)$ between the groups of Like $(M=2.39)$ and Enthusiastic $(M=2.68)$. This finding showed that students who were enthusiastic about college significantly more often expected to "have serious discussions with students whose religious beliefs are very different" than students who liked college and students who were neutral or did not like college.

For the item "STACQ7- Discussions: students of diff political," this ANOVA produced a significant overall finding $\mathrm{F}(2 / 611)=9.558, p<.05$. When the Tukey multiple comparison follow-up test was computed $(p=.000)$, it indicated significant difference in means between the groups of Not like/Neutral $(\mathrm{M}=2.12)$ and Enthusiastic $(\mathrm{M}=2.57)$; and a significant difference $(p=.001)$ between the groups of Like $(\mathrm{M}=2.21)$ and Enthusiastic $(\mathrm{M}=2.57)$. This finding showed that students who were enthusiastic about college significantly more often expected to "have 
serious discussions with students whose political opinions are very different" than students who liked college and students who were neutral or did not like college.

For the item "STACQ9- Discussions: students of diff race," this ANOVA produced a significant overall finding $\mathrm{F}(2 / 611)=9.255, p<.05$. When the Tukey multiple comparison follow-up test was computed $(p=.000)$, it indicated significant difference in means between the groups of Not like/Neutral $(\mathrm{M}=2.31)$ and Enthusiastic $(\mathrm{M}=2.79)$; and a significant difference $(p=.007)$ between the groups of Like $(M=2.48)$ and Enthusiastic $(M=2.79)$. This finding showed that students who were enthusiastic about college significantly more often expected to "have serious discussions with students whose race or ethnic identification is very different" than students who liked college and students who were neutral or do not like college.

For the item "CNTPS2- Topic: Social issues--peace, justice, etc.," this ANOVA produced a significant overall finding $\mathrm{F}(2 / 619)=10.644, p<.05$. When the Tukey multiple comparison follow-up test was computed $(p=.000)$, it indicated significant difference in means between the groups of Not like/Neutral $(\mathrm{M}=2.28)$ and Enthusiastic $(\mathrm{M}=2.72)$; and a significant difference $(p=.001)$ between the groups of Like $(M=2.41)$ and Enthusiastic $(M=2.72)$. This finding showed that students who were enthusiastic about college significantly more often expected to discuss "social issues such as peace, justice, human rights, equality, and race relations" than students who liked college and students who were neutral or did not like college.

For the item "CNTPS3- Topic: Different lifestyles, etc.," this ANOVA produced a significant overall finding $\mathrm{F}(2 / 611)=13.726, p<.05$. When the Tukey multiple comparison follow-up test was computed ( $p=.040$ ), it indicated significant difference in means between the groups of Not Like/Neutral $(\mathrm{M}=2.35)$ and Like $(\mathrm{M}=2.55)$; a significant difference $(p=.000)$ between the groups of Not Like/Neutral $(\mathrm{M}=2.35)$ and Enthusiastic $(\mathrm{M}=2.84)$; and a significant 
difference $(p=.002)$ between the groups of Like $(\mathrm{M}=2.55)$ and Enthusiastic $(\mathrm{M}=2.84)$. This finding showed that students were enthusiastic about college significantly more often expected to discuss "different lifestyles, customs, and religions" than students who liked college and students that were neutral or did not like college. This finding also showed that students liked college significantly more often expected to discuss "different lifestyles, customs, and religions" than students who were neutral or did not like college.

For the item "CNTPS4- Topic: Ideas of writers, etc.," this ANOVA produced a significant overall finding $\mathrm{F}(2 / 612)=14.472, p<.05$. When the Tukey multiple comparison follow-up test was computed $(p=.000)$, it indicated significant difference in means between the groups of Not like/Neutral $(\mathrm{M}=1.94)$ and Enthusiastic $(\mathrm{M}=2.47)$; and a significant difference $(p=.001)$ between the groups of Like $(\mathrm{M}=2.07)$ and Enthusiastic $(\mathrm{M}=2.47)$. This finding showed that students who were enthusiastic about college significantly more often expected to discuss "the ideas and views of writers, philosophers, historians" than students who liked college and students who were neutral or did not like college.

For the item "CNTPS5- Topic: The arts--painting, poetry, etc.," this ANOVA produced a significant overall finding $\mathrm{F}(2 / 615)=3.582, p<.05$. When the Tukey multiple comparison follow-up test was computed ( $p=.029)$, it indicated significant difference in means between the groups of Not like/Neutral $(\mathrm{M}=2.22)$ and Enthusiastic $(\mathrm{M}=2.49)$. This finding showed that students who were enthusiastic about college significantly more often expected to discuss "the arts (painting, poetry, theatrical productions, dance, symphony, movies, etc.)" than students who liked college and students who were neutral or did not like college.

For the item "CNPTS9- Topic: The economy--employment, etc.," this ANOVA produced a significant overall finding $\mathrm{F}(2 / 611)=21.849, p<.05$. When the Tukey multiple comparison 
follow-up test was computed $(p=.015)$, it indicated significant difference in means between the groups of Not Like/Neutral $(\mathrm{M}=2.22)$ and Like $(\mathrm{M}=2.46)$; a significant difference $(p=.000)$ between the groups of Not Like/Neutral $(\mathrm{M}=2.22)$ and Enthusiastic $(\mathrm{M}=2.86)$; and a significant difference $(p=.000)$ between the groups of Like $(\mathrm{M}=2.46)$ and Enthusiastic $(\mathrm{M}=2.86)$. This finding showed that students who were enthusiastic about college significantly more often expected to discuss "the economy (employment, wealth, poverty, debt, trade, etc.)" than students who liked college and students who were neutral or did not like college. This finding also showed that students who liked college significantly more often expected to discuss "the economy (employment, wealth, poverty, debt, trade, etc.)" than students who were neutral or did not like college.

For the item "CNPTS10- Topic: International relations," this ANOVA produced a significant overall finding $\mathrm{F}(2 / 614)=14.075, p<.05$. When the Tukey multiple comparison follow-up test was computed $(p=.000)$, it indicated significant difference in means between the groups of Not like/Neutral $(\mathrm{M}=2.16)$ and Enthusiastic $(\mathrm{M}=2.68)$; and a significant difference $(p=.000)$ between the groups of Like $(\mathrm{M}=2.27)$ and Enthusiastic $(\mathrm{M}=2.68)$. This finding showed that students who were enthusiastic about college significantly more often expected to discuss "international relations (human rights, free trade, military activities, political differences, etc.)" than students liked college and students who were neutral or did not like college. 
Table 42

Means, Standard Deviations, and One-Way Analysis of Variance for the Effects of College

Opinion on Cultural and Social Understanding CSXQ Variables

\begin{tabular}{|c|c|c|c|c|c|c|c|c|c|c|}
\hline \multirow[b]{2}{*}{ Variable } & \multicolumn{2}{|c|}{$\begin{array}{l}\text { Not } \\
\text { Like/Neutral }\end{array}$} & \multicolumn{2}{|l|}{ Like } & \multicolumn{2}{|c|}{ Enthusiastic } & \multirow[b]{2}{*}{$d f$} & \multirow[b]{2}{*}{$F$} & \multirow[b]{2}{*}{$p$} & \multirow[b]{2}{*}{$\eta^{2}$} \\
\hline & $M$ & $S D$ & $M$ & $S D$ & $M$ & $S D$ & & & & \\
\hline $\begin{array}{l}\text { CAMRE1- Go to exhibit- } \\
\text { gallery-performance }\end{array}$ & 1.66 & .852 & 1.83 & .928 & 2.02 & .929 & $2 / 623$ & $6.437^{*}$ & .002 & .02 \\
\hline $\begin{array}{l}\text { CAMRE2- Attend a concert or } \\
\text { other music event }\end{array}$ & 1.91 & .914 & 1.96 & .939 & 2.08 & 1.009 & $2 / 621$ & 1.388 & .250 & .00 \\
\hline $\begin{array}{l}\text { STACQ2- Acquainted: } \\
\text { students of diff background }\end{array}$ & 2.78 & .851 & 2.92 & .840 & 3.25 & .748 & $2 / 624$ & $14.605 *$ & .000 & .04 \\
\hline $\begin{array}{l}\text { STACQ3- Acquainted: } \\
\text { students of diff race }\end{array}$ & 3.02 & .870 & 3.11 & .823 & 3.44 & .648 & $2 / 624$ & $12.847^{*}$ & .000 & .04 \\
\hline $\begin{array}{l}\text { STACQ6- Discussions: } \\
\text { students of diff values }\end{array}$ & 2.45 & .955 & 2.63 & .921 & 2.96 & .923 & $2 / 626$ & $13.329 *$ & .001 & .04 \\
\hline $\begin{array}{l}\text { STACQ8- Discussions: } \\
\text { students of diff religious }\end{array}$ & 2.25 & 1.008 & 2.39 & 1.029 & 2.68 & 1.068 & $2 / 625$ & $7.546^{*}$ & .000 & .02 \\
\hline $\begin{array}{l}\text { STACQ7- Discussions: } \\
\text { students of diff political }\end{array}$ & 2.12 & .983 & 2.21 & 1.000 & 2.57 & .971 & $2 / 611$ & $9.558^{*}$ & .000 & .03 \\
\hline $\begin{array}{l}\text { STACQ9- Discussions: } \\
\text { students of diff race }\end{array}$ & 2.31 & .975 & 2.48 & 1.026 & 2.79 & 1.021 & $2 / 611$ & $9.255^{*}$ & .000 & .03 \\
\hline $\begin{array}{l}\text { CNTPS2- Topic: Social } \\
\text { issues--peace,justice, etc. }\end{array}$ & 2.28 & .844 & 2.41 & .893 & 2.72 & .902 & $2 / 619$ & $10.664 *$ & .000 & .03 \\
\hline $\begin{array}{l}\text { CNTPS3- Topic: Different } \\
\text { lifestyles, etc. }\end{array}$ & 2.35 & .862 & 2.55 & .877 & 2.84 & .863 & $2 / 611$ & $13.726^{*}$ & .000 & .04 \\
\hline $\begin{array}{l}\text { CNTPS4- Topic: Ideas of } \\
\text { writers, etc. }\end{array}$ & 1.94 & .894 & 2.07 & .885 & 2.47 & 1.036 & $2 / 612$ & $14.472 *$ & .000 & .05 \\
\hline $\begin{array}{l}\text { CNTPS5- Topic: The arts-- } \\
\text { painting, poetry, etc. }\end{array}$ & 2.22 & .919 & 2.29 & .960 & 2.49 & 1.023 & $2 / 615$ & $3.582 *$ & .000 & .01 \\
\hline $\begin{array}{l}\text { CNPTS9- Topic: The } \\
\text { economy--employment, etc. }\end{array}$ & 2.22 & .848 & 2.46 & .875 & 2.86 & .903 & $2 / 611$ & $21.849^{*}$ & .000 & .06 \\
\hline $\begin{array}{l}\text { CNPTS10- Topic: } \\
\text { International relations }\end{array}$ & 2.16 & .960 & 2.27 & .921 & 2.68 & .985 & $2 / 614$ & $14.075^{*}$ & .000 & .04 \\
\hline
\end{tabular}


College opinion/quantitative reasoning. Analysis of Variance (ANOVA) examined significant differences in College Opinion (independent variable) by means of the Quantitative Reasoning CSXQ College Activity Items (dependent variables). This analysis yielded statistically significant differences (at least $p<.05$ ) with both CSXQ items (see Table 43). For the item, "SCI1- Memorize formulas-definitions-concepts," this ANOVA produced a significant overall finding $\mathrm{F}(2 / 611)=3.726, p<.05$. When the Tukey multiple comparison follow-up test was computed $(p=.019)$, it indicated a significant difference in means between the groups of Not Like/Neutral $(M=2.72)$ and Enthusiastic $(M=2.99)$. This finding showed that students who were enthusiastic about college significantly more often expected to "memorize formulas, definitions, technical terms and concepts" than students who were neutral or did not like college.

For the item, "SCI2- Express relationships using math terms," this ANOVA produced a significant overall finding $\mathrm{F}(2 / 611)=4.387, p<.05$. When the Tukey multiple comparison follow-up test was computed $(p=.019)$, it indicated a significant difference in means between the groups of Not Like/Neutral $(M=2.36)$ and Enthusiastic $(M=2.68)$. This finding showed that students who were enthusiastic about college significantly more often expected to "express a set of relationships using mathematical terms" than students who were neutral or did not like college. 
Table 43

Means, Standard Deviations, and One-Way Analysis of Variance for the Effects of College Opinion on Quantitative Reasoning CSXQ Variables

\begin{tabular}{|c|c|c|c|c|c|c|c|c|c|}
\hline \multirow[b]{2}{*}{ Variable } & \multicolumn{2}{|c|}{$\begin{array}{l}\text { Not } \\
\text { Like/Neutral }\end{array}$} & \multicolumn{2}{|l|}{ Like } & \multicolumn{2}{|c|}{ Enthusiastic } & \multirow[b]{2}{*}{$d f$} & \multirow[b]{2}{*}{$F$} & \multirow[b]{2}{*}{$\eta^{2}$} \\
\hline & $M$ & $S D$ & $M$ & $S D$ & $M$ & $S D$ & & & \\
\hline $\begin{array}{l}\text { SCI1- Memorize } \\
\text { formulas-definitions- } \\
\text { concepts }\end{array}$ & 2.72 & .946 & 2.87 & .838 & 2.99 & .944 & $2 / 611$ & $3.726^{*}$ & .01 \\
\hline $\begin{array}{l}\text { SCI2- Express } \\
\text { relationships using math } \\
\text { terms }\end{array}$ & 2.36 & 1.022 & 2.47 & .930 & 2.68 & 1.017 & $2 / 611$ & $4.387^{*}$ & .01 \\
\hline
\end{tabular}

College opinion/scientific reasoning. Analysis of Variance (ANOVA) examined significant differences in College Opinion (independent variable) by means of the Scientific Reasoning CSXQ College Activity Items (dependent variables). This analysis yielded statistically significant differences (at least $p<.05$ ) with all three CSXQ items (see Table 44). For the item, "SCI5- Complete an experiment with scientific methods," this ANOVA produced a significant overall finding $\mathrm{F}(2 / 610)=3.422, p<.05$. When the Tukey multiple comparison follow-up test was computed $(p=.028)$, it indicated a significant difference in means between the groups of Not Like/Neutral $(M=2.14)$ and Enthusiastic $(M=2.42)$. This finding showed that students who were enthusiastic about college significantly more often expected to "complete an experiment or project using scientific methods" than students who were neutral or did not like college.

For the item, "CNTPS6- Topic: Science--theories, etc.," this ANOVA produced a significant overall finding $\mathrm{F}(2 / 610)=13.019, p<.05$. When the Tukey multiple comparison follow-up test was computed $(p=.000)$, it indicated a significant difference in means between the 
groups of Not Like/Neutral $(\mathrm{M}=1.81)$ and Enthusiastic $(\mathrm{M}=2.32)$; and a significant difference $(p=.000)$ between the groups of Like $(\mathrm{M}=1.97)$ and Enthusiastic $(\mathrm{M}=2.32)$. This finding showed that students who were enthusiastic about college significantly more often expected to discuss "science (theories, experiments, methods, etc.)" than students who liked college or students who were neutral or did not like college.

For the item "CNPTS8- Topic: Social-ethical issues re: science," this ANOVA produced a significant overall finding $\mathrm{F}(2 / 616)=15.373, p<.05$. When the Tukey multiple comparison follow-up test was computed ( $p=.023$ ), it indicated significant difference in means between the groups of Not Like/Neutral $(\mathrm{M}=2.00)$ and Like $(\mathrm{M}=2.23)$; a significant difference $(p=.000)$ between the groups of Not Like/Neutral $(\mathrm{M}=2.00)$ and Enthusiastic $(\mathrm{M}=2.56)$; and a significant difference $(p=.001)$ between the groups of Like $(\mathrm{M}=2.23)$ and Enthusiastic $(\mathrm{M}=2.56)$. This finding showed that students who were enthusiastic about college significantly more often expected to discuss "social and ethical issues related to science and technology such as energy, pollution, chemicals, genetics, and military use" than students who liked college and students who were neutral or did not like college. This finding also showed that students who liked college significantly more often expected to discuss "social and ethical issues related to science and technology such as energy, pollution, chemicals, genetics, military use" than students who were neutral or did not like college. 
Table 44

Means, Standard Deviations, and One-Way Analysis of Variance for the Effects of College Opinion on Scientific Reasoning CSXQ Variables

\begin{tabular}{|c|c|c|c|c|c|c|c|c|c|c|}
\hline \multirow[b]{2}{*}{ Variable } & \multicolumn{2}{|c|}{$\begin{array}{l}\text { Not } \\
\text { Like/Neutral }\end{array}$} & \multicolumn{2}{|c|}{ Like } & \multicolumn{2}{|c|}{ Enthusiastic } & \multirow[b]{2}{*}{$D f$} & \multirow[b]{2}{*}{$F$} & \multirow[b]{2}{*}{$p$} & \multirow[b]{2}{*}{$\eta^{2}$} \\
\hline & $M$ & $S D$ & $M$ & $S D$ & $M$ & $S D$ & & & & \\
\hline $\begin{array}{l}\text { SCI5- Complete } \\
\text { an experiment w- } \\
\text { sci methods }\end{array}$ & 2.14 & .966 & 2.31 & .976 & 2.42 & 1.067 & $2 / 610$ & $3.422 *$ & .033 & .00 \\
\hline $\begin{array}{l}\text { CNTPS6- Topic: } \\
\text { Science--theories, } \\
\text { etc. }\end{array}$ & 1.81 & .850 & 1.97 & .910 & 161 & 2.32 & $2 / 610$ & $13.019^{*}$ & .000 & .00 \\
\hline $\begin{array}{l}\text { CNPTS8- Topic: } \\
\text { Social-ethical } \\
\text { issues re: science }\end{array}$ & 2.00 & .846 & 2.23 & .906 & 2.56 & .984 & $2 / 616$ & $15.373^{*}$ & .000 & .00 \\
\hline
\end{tabular}

College opinion and quantitative/scientific reasoning. Analysis of Variance

(ANOVA) examined significant differences in College Opinion (independent variable) by means of the Quantitative/Scientific Reasoning CSXQ College Activity Items (dependent variables). This analysis yielded statistically significant differences (at least $p<.05$ ) with both items (see Table 45). For the item, "SCI3- Explain scientific concept to others," this ANOVA produced a significant overall finding $\mathrm{F}(2 / 609)=9.330, p<.05$. When the Tukey multiple comparison follow-up test was computed $(p=.003)$, it indicated significant difference in means between the groups of Not Like/Neutral $(M=2.11)$ and Like $(M=2.42)$; and a significant difference $(p=.000)$ between the groups of Not Like/Neutral $(M=2.11)$ and Enthusiastic $(M=2.55)$. This finding showed that students who were neutral or did not like college significantly more often expected to "explain your understanding of some scientific or mathematical theory, principle or concept to 
someone else (classmate, co-worker, etc.)" than students who were enthusiastic about college and students who liked college.

For the item, "SCI4- Read articles about science not assigned," this ANOVA produced a significant overall finding $\mathrm{F}(2 / 610)=3.003, p<.05$. When the Tukey multiple comparison follow-up test was computed $(p=.047)$, it indicated significant difference in means between the groups of Not Like/Neutral $(M=1.99)$ and Enthusiastic $(M=2.25)$. This finding showed that students who were enthusiastic about college significantly more often expected to "read articles about scientific or mathematical theories or concepts in addition to those assigned for a class" than students who were neutral or did not like college.

Table 45

Means, Standard Deviations, and One-Way Analysis of Variance for the Effects of College Opinion on Quantitative/Scientific Reasoning CSXQ Variables

\begin{tabular}{|c|c|c|c|c|c|c|c|c|c|c|}
\hline \multirow[b]{2}{*}{ Variable } & \multicolumn{2}{|c|}{$\begin{array}{l}\text { Not } \\
\text { Like/Neutral }\end{array}$} & \multicolumn{2}{|l|}{ Like } & \multicolumn{2}{|c|}{ Enthusiastic } & \multirow[b]{2}{*}{$d f$} & \multirow[b]{2}{*}{$F$} & \multirow[b]{2}{*}{$P$} & \multirow[b]{2}{*}{$\eta^{2}$} \\
\hline & $M$ & $S D$ & $M$ & $S D$ & $M$ & $S D$ & & & & \\
\hline $\begin{array}{l}\text { SCI3- Explain } \\
\text { scientific concept } \\
\text { to others }\end{array}$ & 2.11 & .070 & 2.42 & .951 & 2.55 & .957 & $2 / 609$ & $9.330 *$ & .000 & .03 \\
\hline $\begin{array}{l}\text { SCI4- Read articles } \\
\text { about science not } \\
\text { assigned }\end{array}$ & 1.99 & .950 & 2.07 & .941 & 2.25 & 1.081 & $2 / 610$ & $3.003 *$ & .050 & .01 \\
\hline
\end{tabular}

\section{Research Question 2D: Academic Major}

This research question 2D looked for significant differences in the CSXQ General Education Variables based upon the students' intended academic major. A one-way analysis of variance (ANOVA) was calculated to examine the effect of academic major on student expectations of college. Data for the Academic Major were determined by the CSXQ item 
which asks students to identify their intended major in college. Six groups were created based upon the students' responses: (a) Math, Science and Engineering ( $\mathrm{n}=131)$, (b) Business and Public Services (n=83), (c) Liberal Arts/General Studies (n=104), (d) Education (n=30), (e) Healthcare ( $\mathrm{n}=74)$, and (f) Pre-professional ( $\mathrm{n}=12)$. A statistically significant effect was found with ten items in six general education clusters: Information Literacy, Communication, Cultural and Social Understanding, Quantitative Reasoning, Scientific Reasoning, and Quantitative/Scientific Reasoning.

Academic major/information literacy. Analysis of Variance (ANOVA) examined significant differences in Academic Major (independent variable) by means of the Information Literacy CSXQ College Activity Items (dependent variables). This analysis yielded an overall statistically significant difference (at least $p<.05$ ) with the one CSXQ item (see Table 46). For the item "CNTPS7- Topic: Computers and other technologies" this ANOVA produced a significant overall finding $\mathrm{F}(5 / 418)=7.865, p<.05$. When the Tukey multiple comparison follow-up test was computed $(p=.000)$, it indicated a significant difference in means between the Math, Science and Engineering group $(M=2.93)$ and the Business and Public Service $(M=2.30)$, Liberal Arts/General Studies $(\mathrm{M}=2.38)$, and Education $(\mathrm{M}=2.00)$ groups. This finding showed that students who intended to major in Math, Science and Engineering significantly more often expected to discuss "computers and other technologies" than students who intended to major in Business and Public Service, Liberal Arts/General Studies, and Education. 
Table 46

Means, Standard Deviations, and One-Way Analysis of Variance for the Effects of Academic Major on Information Literacy CSXQ

\section{Variables}

\begin{tabular}{|c|c|c|c|c|c|c|c|c|c|c|c|c|c|c|c|c|}
\hline \multirow[b]{2}{*}{ Variable } & \multicolumn{2}{|c|}{ MSE } & \multicolumn{2}{|c|}{ BUS/PS } & \multicolumn{2}{|c|}{ LA/GS } & \multicolumn{2}{|l|}{ EDU } & \multicolumn{2}{|l|}{$\mathrm{HE}$} & \multicolumn{2}{|l|}{ PRE } & \multirow[b]{2}{*}{$d f$} & \multirow[b]{2}{*}{$F$} & \multirow[b]{2}{*}{$p$} & \multirow[b]{2}{*}{$\eta^{2}$} \\
\hline & $M$ & $S D$ & $M$ & $S D$ & $M$ & $S D$ & $M$ & $S D$ & $M$ & $S D$ & $M$ & $S D$ & & & & \\
\hline $\begin{array}{l}\text { LIBIT2- Use index or } \\
\text { database to find material }\end{array}$ & 2.78 & .963 & 2.65 & 1.011 & 2.81 & .961 & 2.77 & .971 & 2.81 & .917 & 2.58 & 1.165 & $5 / 420$ & .411 & .841 & .00 \\
\hline $\begin{array}{l}\text { LIBIT5- Use computer- } \\
\text { word processor for paper }\end{array}$ & 3.60 & .711 & 3.39 & .907 & 3.59 & .907 & 3.57 & .817 & 3.66 & .625 & 3.50 & .905 & $5 / 422$ & 1.177 & .320 & .01 \\
\hline $\begin{array}{l}\text { LIBIT8- Search internet } \\
\text { for course material }\end{array}$ & 3.45 & .790 & 3.26 & .853 & 3.50 & .832 & 3.41 & .780 & 3.41 & .859 & 3.33 & .778 & $5 / 419$ & .809 & .543 & .01 \\
\hline $\begin{array}{l}\text { CRSE11- Work on project } \\
\text { integrating ideas }\end{array}$ & 2.84 & .824 & 2.76 & .825 & 2.84 & .887 & 3.00 & .845 & 2.97 & .844 & 3.17 & .577 & $5 / 422$ & 1.008 & .412 & .01 \\
\hline $\begin{array}{l}\text { CNTPS7- Topic: } \\
\text { Computers and other } \\
\text { technologies }\end{array}$ & 2.93 & .873 & 2.30 & .877 & 2.38 & 1.038 & 2.00 & .871 & 2.58 & 1.071 & 2.55 & 1.128 & $5 / 418$ & $7.865^{*}$ & .000 & .09 \\
\hline
\end{tabular}

Education. HE-Healthcare. PRE-Pre-professional. 
Academic major/communication. Analysis of Variance (ANOVA) examined significant differences in Academic Major (independent variable) by means of the Communication CSXQ College Activity Items (dependent variables). This analysis yielded an overall statistically significant difference (at least $p<.05$ ) with the one CSXQ item (see Table 47). For the item "CRSE6- Summarize major points and information," this ANOVA produced a significant overall finding $\mathrm{F}(5 / 417)=3.115, p<.05$. The Tukey multiple comparison follow-up test indicated no significant differences but a strong trend $(p=.060)$ between the groups of Liberal Arts/General Studies $(M=2.66)$ and Healthcare $(M=3.01)$. This finding showed a strong trend that students who intended to major in Healthcare more often expected to "summarize major points and information" than students who intended to major in Liberal Arts/General Studies. 
Table 47

Means, Standard Deviations, and One-Way Analysis of Variance for the Effects of Academic Major on Communication CSXQ

Variables

\begin{tabular}{|c|c|c|c|c|c|c|c|c|c|c|c|c|c|c|c|c|}
\hline \multirow[b]{2}{*}{ Variable } & \multicolumn{2}{|c|}{ MSE } & \multicolumn{2}{|c|}{ BUS/PS } & \multicolumn{2}{|c|}{ LA/GS } & \multicolumn{2}{|l|}{ EDU } & \multicolumn{2}{|l|}{$\mathrm{HE}$} & \multicolumn{2}{|l|}{ PRE } & \multirow[b]{2}{*}{$d f$} & \multirow[b]{2}{*}{$F$} & \multirow[b]{2}{*}{$p$} & \multirow[b]{2}{*}{$\eta^{2}$} \\
\hline & $M$ & $S D$ & $M$ & $S D$ & $M$ & $S D$ & $M$ & $S D$ & $M$ & $S D$ & $M$ & $S D$ & & & & \\
\hline $\begin{array}{l}\text { CRSE3- } \\
\text { Contribute } \\
\text { to class } \\
\text { discussions }\end{array}$ & 2.74 & .879 & 2.83 & .787 & 2.82 & .763 & 2.70 & 1.022 & 2.86 & .787 & 2.92 & 1.084 & $5 / 421$ & .368 & .870 & .00 \\
\hline $\begin{array}{l}\text { CRSE6- } \\
\text { Summarize } \\
\text { major } \\
\text { points and } \\
\text { information }\end{array}$ & 2.83 & .782 & 2.70 & .911 & 2.66 & .873 & 3.07 & .785 & 3.01 & .760 & 3.27 & .905 & $5 / 417$ & $3.115 *$ & .009 & .04 \\
\hline $\begin{array}{l}\text { CRSE10- } \\
\text { Explain } \\
\text { course } \\
\text { material to } \\
\text { others }\end{array}$ & 2.75 & .810 & 2.65 & .837 & 2.76 & .846 & 2.67 & .802 & 2.88 & .763 & 2.50 & .905 & $5 / 423$ & .897 & .483 & .01 \\
\hline $\begin{array}{l}\text { CINIF6- } \\
\text { Persuade } \\
\text { others to } \\
\text { change their } \\
\text { minds }\end{array}$ & 2.63 & .846 & 2.58 & .823 & 2.68 & .877 & 2.43 & .858 & 2.44 & .866 & 2.42 & .966 & $5 / 422$ & 1.030 & .399 & .01 \\
\hline
\end{tabular}


Academic major/critical thinking. Analysis of Variance (ANOVA) examined significant differences in Academic Major (independent variable) by means of the Critical Thinking CSXQ College Activity Items (dependent variables). This analysis yielded no significant differences with the any of the CSXQ items (see Table 48). 
Table 48

Means, Standard Deviations, and One-Way Analysis of Variance for the Effects of Academic Major on Critical Thinking CSXQ

Variables

\begin{tabular}{|c|c|c|c|c|c|c|c|c|c|c|c|c|c|c|c|c|}
\hline \multirow[b]{2}{*}{ Variable } & \multicolumn{2}{|l|}{ MSE } & \multicolumn{2}{|c|}{ BUS/PS } & \multicolumn{2}{|c|}{ LA/GS } & \multicolumn{2}{|l|}{ EDU } & \multicolumn{2}{|l|}{$\mathrm{HE}$} & \multicolumn{2}{|l|}{ PRE } & \multirow[b]{2}{*}{$d f$} & \multirow[b]{2}{*}{$F$} & \multirow[b]{2}{*}{$p$} & \multirow[b]{2}{*}{$\eta^{2}$} \\
\hline & $M$ & $S D$ & $M$ & $S D$ & $M$ & $S D$ & $M$ & $S D$ & $M$ & $S D$ & $M$ & $S D$ & & & & \\
\hline $\begin{array}{l}\text { CRSE5- Put together different } \\
\text { facts and ideas }\end{array}$ & 3.03 & .803 & 2.76 & .825 & 3.00 & .728 & 2.86 & .875 & 3.08 & .707 & 3.27 & .786 & $5 / 416$ & 2.174 & .000 & .03 \\
\hline $\begin{array}{l}\text { CRSE8- Apply class material to } \\
\text { other areas }\end{array}$ & 2.91 & .879 & 2.85 & .944 & 2.90 & .924 & 2.97 & .850 & 3.12 & .875 & 3.08 & .900 & $5 / 423$ & .873 & .000 & .01 \\
\hline $\begin{array}{l}\text { CRSE9- Use info from other } \\
\text { areas in class }\end{array}$ & 2.94 & .864 & 2.95 & .874 & 2.97 & .902 & 2.97 & .809 & 3.00 & .799 & 2.58 & 1.240 & $5 / 423$ & .490 & .000 & .01 \\
\hline $\begin{array}{l}\text { CNINF2- Explore different } \\
\text { ways of thinking }\end{array}$ & 2.83 & .846 & 2.68 & .839 & 2.97 & .830 & 2.86 & .789 & 2.86 & .873 & 2.91 & .831 & $5 / 412$ & 1.130 & .000 & .01 \\
\hline $\begin{array}{l}\text { CINIF5- Change opinion } \\
\text { because of others }\end{array}$ & 2.34 & .753 & 2.30 & .818 & 2.48 & .765 & 2.17 & .986 & 2.30 & .716 & 2.50 & 1.000 & $5 / 423$ & 1.074 & .034 & .01 \\
\hline
\end{tabular}

${ }^{*} \mathrm{p}<.05 . \eta^{2}$ is rounded. MSE-Math, Science and Engineering. BUS/PS-Business and Public Services. LA/GS-Liberal Arts/General Studies. EDU-

Education. HE-Healthcare. PRE-Pre-professional. 
Academic major/cultural and social understanding. Analysis of Variance (ANOVA) examined significant differences in Academic Major (independent variable) by means of the Cultural and Social Understanding CSXQ College Activity Items (dependent variables). This analysis yielded an overall statistically significant difference (at least $p<.05$ ) with one CSXQ item (see Table 49). For the item "CNTPS5- Topic: The arts--painting, poetry, etc.," this ANOVA produced a significant overall finding $\mathrm{F}(5 / 421)=2.501, p<.05$. When the Tukey multiple comparison follow-up test was computed $(p=.036)$, it indicated a significant difference in means between the groups of Liberal Arts/General Studies $(\mathrm{M}=2.63)$ and Business/Public Service $(M=2.21)$. This finding showed that students who intended to major in Liberal Arts/General Studies significantly more often expected to discuss "the arts (painting, poetry, theatrical productions, dance, symphony, movies, etc.)" than students who intended to major in Business and Public Service. 
Table 49

Means, Standard Deviations, and One-Way Analysis of Variance for the Effects of Academic Major on Cultural and Social

\section{Understanding CSXQ Variables}

\begin{tabular}{|c|c|c|c|c|c|c|c|c|c|c|c|c|c|c|c|c|}
\hline \multirow[b]{2}{*}{ Variable } & \multicolumn{2}{|c|}{ MSE } & \multicolumn{2}{|c|}{ BUS/PS } & \multicolumn{2}{|c|}{ LA/GS } & \multicolumn{2}{|l|}{ EDU } & \multicolumn{2}{|l|}{$\mathrm{HE}$} & \multicolumn{2}{|l|}{ PRE } & \multirow[b]{2}{*}{$d f$} & \multirow[b]{2}{*}{$F$} & \multirow[b]{2}{*}{$p$} & \multirow[b]{2}{*}{$\eta^{2}$} \\
\hline & $M$ & $S D$ & $M$ & $S D$ & $M$ & $S D$ & $M$ & $S D$ & $M$ & $S D$ & $M$ & $S D$ & & & & \\
\hline $\begin{array}{l}\text { CAMRE1- Go to exhibit- } \\
\text { gallery-performance }\end{array}$ & 1.74 & .847 & 1.83 & .979 & 1.95 & 1.023 & 1.63 & .890 & 1.84 & .966 & 2.00 & 1.000 & $5 / 425$ & .906 & .477 & .01 \\
\hline $\begin{array}{l}\text { CAMRE2- Attend a } \\
\text { concert or other music } \\
\text { event }\end{array}$ & 1.94 & .938 & 1.89 & .889 & 2.07 & 1.031 & 2.00 & 1.017 & 1.97 & .979 & 2.36 & .924 & $5 / 424$ & .713 & .614 & .01 \\
\hline $\begin{array}{l}\text { STACQ2- Acquainted: } \\
\text { students of diff } \\
\text { background }\end{array}$ & 2.85 & .789 & 2.96 & .823 & 3.06 & .873 & 3.20 & .805 & 2.93 & .865 & 2.92 & .900 & $5 / 425$ & 1.228 & .295 & .01 \\
\hline $\begin{array}{l}\text { STACQ3- Acquainted: } \\
\text { students of diff race }\end{array}$ & 3.11 & .787 & 3.12 & .802 & 3.17 & .857 & 3.20 & .847 & 3.29 & .754 & 3.17 & .835 & $5 / 426$ & .538 & .748 & .01 \\
\hline $\begin{array}{l}\text { STACQ6- Discussions: } \\
\text { students of diff values }\end{array}$ & 2.63 & .962 & 2.67 & .925 & 2.67 & .984 & 2.87 & 1.042 & 2.76 & .962 & 2.92 & .900 & $5 / 427$ & .505 & .773 & .01 \\
\hline $\begin{array}{l}\text { STACQ8- Discussions: } \\
\text { students of diff religious }\end{array}$ & 2.35 & 1.022 & 2.41 & 1.060 & 2.48 & 1.046 & 2.70 & 1.119 & 2.53 & 1.029 & 2.50 & 1.087 & $5 / 426$ & .716 & .612 & .01 \\
\hline $\begin{array}{l}\text { STACQ7- Discussions: } \\
\text { students of diff political }\end{array}$ & 2.26 & .921 & 2.18 & 1.022 & 2.46 & 1.050 & 2.43 & 1.104 & 2.25 & 1.079 & 1.82 & .751 & $5 / 416$ & 1.431 & .212 & .02 \\
\hline $\begin{array}{l}\text { STACQ9- Discussions: } \\
\text { students of diff race }\end{array}$ & 2.42 & 1.024 & 2.51 & .985 & 2.70 & 1.022 & 2.80 & 1.157 & 2.51 & .993 & 2.82 & 1.168 & $5 / 416$ & 1.365 & .236 & .02 \\
\hline $\begin{array}{l}\text { CNTPS2- Topic: Social } \\
\text { issues--peace,justice, etc. }\end{array}$ & 2.39 & .887 & 2.37 & .809 & 2.57 & .914 & 2.40 & .770 & 2.54 & 1.006 & 2.50 & .798 & $5 / 422$ & .837 & .524 & .01 \\
\hline
\end{tabular}


Table 49 (continued)

Means, Standard Deviations, and One-Way Analysis of Variance for the Effects of Academic Major on Cultural and Social

\section{Understanding CSXQ Variables}

\begin{tabular}{|c|c|c|c|c|c|c|c|c|c|c|c|c|c|c|c|c|}
\hline \multirow[b]{2}{*}{ Variable } & \multicolumn{2}{|l|}{ MSE } & \multicolumn{2}{|c|}{ BUS/PS } & \multicolumn{2}{|c|}{ LA/GS } & \multicolumn{2}{|l|}{ EDU } & \multicolumn{2}{|l|}{$\mathrm{HE}$} & \multicolumn{2}{|l|}{ PRE } & \multirow[b]{2}{*}{$d f$} & \multirow[b]{2}{*}{$F$} & \multirow[b]{2}{*}{$p$} & \multirow[b]{2}{*}{$\eta^{2}$} \\
\hline & $M$ & $S D$ & $M$ & $S D$ & $M$ & $S D$ & $M$ & $S D$ & $M$ & $S D$ & $M$ & $S D$ & & & & \\
\hline $\begin{array}{l}\text { CNTPS3- Topic: } \\
\text { Different lifestyles, } \\
\text { etc. }\end{array}$ & 2.43 & .846 & 2.53 & .826 & 2.69 & .944 & 2.72 & .882 & 2.62 & .806 & 2.75 & 1.055 & $5 / 415$ & 1.449 & .206 & .02 \\
\hline $\begin{array}{l}\text { CNTPS4- Topic: } \\
\text { Ideas of writers, etc. }\end{array}$ & 2.17 & .960 & 2.09 & .938 & 2.28 & 1.050 & 2.10 & 1.029 & 2.11 & .956 & 2.45 & .934 & $5 / 416$ & .598 & .701 & .02 \\
\hline $\begin{array}{l}\text { CNTPS5- Topic: } \\
\text { The arts--painting, } \\
\text { poetry, etc. }\end{array}$ & 2.29 & .930 & 2.21 & .939 & 2.63 & 1.029 & 2.53 & 1.042 & 2.26 & .888 & 2.36 & 1.027 & $5 / 421$ & $2.501 *$ & .030 & .03 \\
\hline $\begin{array}{l}\text { CNPTS9- Topic: } \\
\text { The economy-- } \\
\text { employment, etc. }\end{array}$ & 2.54 & .848 & 2.49 & .933 & 2.64 & .952 & 2.50 & .938 & 2.63 & .882 & 2.55 & .820 & $5 / 419$ & .381 & .862 & .00 \\
\hline $\begin{array}{l}\text { CNPTS10- Topic: } \\
\text { International } \\
\text { relations }\end{array}$ & 2.36 & .950 & 2.37 & .949 & 2.49 & .982 & 2.23 & .935 & 2.36 & 1.011 & 2.55 & .820 & $5 / 420$ & .489 & .785 & .01 \\
\hline
\end{tabular}


Academic major/quantitative reasoning. Analysis of Variance (ANOVA) examined significant differences in Academic Major (independent variable) by means of the Quantitative Reasoning CSXQ College Activity Items (dependent variables). This analysis yielded an overall statistically significant difference (at least $p<.05$ ) with both CSXQ items (see Table 50). For the item "SCI1- Memorize formulas-definitions-concepts" this ANOVA produced a significant overall finding $\mathrm{F}(5 / 418)=4.499, p<.05$. When the Tukey multiple comparison follow-up test was computed $(p=.002)$, it indicated significant difference in means between the groups of Liberal Arts/General Studies $(M=2.63)$ and Math, Science and Engineering $(M=3.09)$; and a significant difference $(\mathrm{p}=.010)$ between the groups of Liberal Arts/General Studies $(\mathrm{M}=2.63)$ and Healthcare $(M=3.10)$. This finding showed that students who intended to major in Math, Science and Engineering and Healthcare significantly more often expected to "memorize formulas, definitions, technical terms and concepts" than students who intended to major in Liberal Arts/General Studies.

For the item "SCI2- Express relationships using math terms" this ANOVA produced a significant overall finding $\mathrm{F}(5 / 418)=5.266, p<.05$. When the Tukey multiple comparison follow-up test was computed $(p=.017)$, it indicated significant difference in means between the groups of Liberal Arts/General Studies $(M=2.26)$ and Healthcare $(M=2.74)$; a significant differences $(p=.027)$ between the group of Math Science and Engineering $(\mathrm{M}=2.82)$ and the groups of Liberal Arts/General Studies $(\mathrm{M}=2.26)$; and a significant difference $(p=.000)$ between the groups of Math, Science and Engineering $(M=2.82)$ and Business/Public Services $(M=2.40)$. This finding showed that students who intended to major in Math, Science and Engineering and Healthcare significantly more often expected to "express a set of relationships using mathematical terms" than students who intended to major in Liberal Arts/General Studies. This 
finding also showed that students who intended to major in Math, Science and Engineering significantly more often expected to "express a set of relationships using mathematical terms" than students who intended to major in Business and Public Services. 
Table 50

Means, Standard Deviations, and One-Way Analysis of Variance for the Effects of Academic Major on Quantitative Reasoning CSXQ

Variables

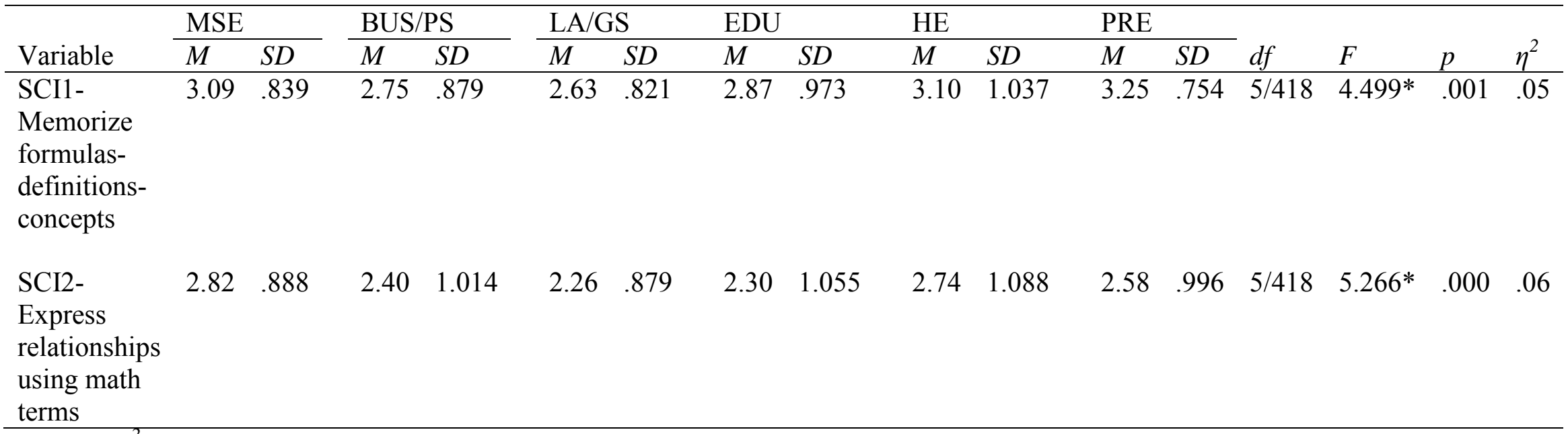

terms

${ }^{*} \mathrm{p}<.05 . \eta^{2}$ is rounded. MSE-Math, Science and Engineering. BUS/PS-Business and Public Services. LA/GS-Liberal Arts/General

Studies. EDU-Education. HE-Healthcare. PRE-Pre-professional. 
Academic major/scientific reasoning. Analysis of Variance (ANOVA) examined significant differences in Academic Major by means of the Scientific Reasoning CSXQ College Activity Items (dependent variables). This analysis yielded statistically significant differences (at least $p<.05$ ) with all three CSXQ items (see Table 51). For the item "SCI5- Complete an experiment w-sci methods" this ANOVA produced a significant overall finding $\mathrm{F}(5 / 417)=$ 2.722, $p<.05$. When the Tukey multiple comparison follow-up test was computed $(p=.023)$, it indicated a significant difference in means between the groups of Math, Science and Engineering $(M=2.59)$ and Liberal Arts/General Studies $(M=2.17)$. This finding showed that students who intended to major in Math, Science and Engineering significantly more often expected to "complete and experiment or project using scientific methods" than students who intended to major in Liberal Arts/General Studies.

For the item "CNTPS6- Topic: Science--theories, etc.," this ANOVA produced a significant overall finding $\mathrm{F}(5 / 417)=5.145, p<.05$. When the Tukey multiple comparison follow-up test was computed, it indicated a strong trend between the group of Math, Science, and Engineering $(\mathrm{M}=2.36)$ and the group of Business/Public Service $(\mathrm{M}=1.90 ; \mathrm{p}=.10)$. It also indicated a significant difference in means between the group of Math, Science and Engineering $(M=2.36)$ and the groups of Liberal Arts/General Studies $(M=1.94 ; p=.013)$ and Education $(\mathrm{M}=1.63 ; \mathrm{p}=.003)$. This finding showed that students who intended to major in Math, Science and Engineering significantly more often expected to discuss "science (theories, experiments, methods, etc.)" than students who intended to major in Business and Public Services, Liberal Arts/General Studies, and Education.

For the item "CNPTS8- Topic: Social-ethical issues re: science" this ANOVA produced a significant overall finding $\mathrm{F}(5 / 421)=2.933, p<.05$. When the Tukey multiple comparison 
follow-up test was computed $(p=.019)$, it indicated a significant difference in means between the groups of Math, Science and Engineering $(\mathrm{M}=2.49)$ and Education $(\mathrm{M}=1.90)$. This finding showed that students who intended to major in Math, Science and Engineering and significantly more often expected to discuss "social and ethical issues related to science and technology such as energy, pollution, chemicals, genetics, and military use" than students who intended to major in Education. 
Table 51

Means, Standard Deviations, and One-Way Analysis of Variance for the Effects of Academic Major on Scientific Reasoning CSXQ

Variables

\begin{tabular}{|c|c|c|c|c|c|c|c|c|c|c|c|c|c|c|c|}
\hline Variable & \multicolumn{2}{|c|}{ MSE } & \multicolumn{2}{|c|}{ BUS/PS } & \multicolumn{2}{|c|}{ LA/GS } & \multicolumn{2}{|c|}{ EDU } & \multicolumn{2}{|c|}{$\mathrm{HE}$} & \multicolumn{2}{|c|}{ PRE } & $d f$ & $F$ & $p$ \\
\hline
\end{tabular}

Complete

an

experiment

W-sci

methods

$\begin{array}{lllllllllllllllll}\text { CNTPS6- } & 2.36 & .994 & 1.90 & .917 & 1.94 & .938 & 1.63 & .718 & 2.17 & 1.035 & 2.55 & .934 & 5 / 417 & 5.145^{*} & .000 & .06\end{array}$

Topic:

Science--

theories,

etc.

$\begin{array}{llllllllllllllllllll}\text { CNPTS8- } & 2.49 & .856 & 2.17 & .798 & 2.26 & .954 & 1.90 & .885 & 2.33 & 1.088 & 2.64 & 1.027 & 5 / 421 & 2.933 * & .013 & .03\end{array}$

Topic:

Social-

ethical

issues re:

science

${ }^{*} \mathrm{p}<.05 . \eta^{2}$ is rounded. MSE-Math, Science and Engineering. BUS/PS-Business and Public Services. LA/GS-Liberal Arts/General

Studies. EDU-Education. HE-Healthcare. PRE-Pre-professional. 
Academic major/quantitative and scientific reasoning. Analysis of Variance

(ANOVA) examined significant differences in Academic Major (independent variable) by means of the Quantitative and Scientific Reasoning CSXQ College Activity Items (dependent variables). This analysis yielded an overall statistically significant difference (at least $p<.05$ ) with the both CSXQ items (see Table 52). For the item "SCI3- Explain scientific concept to others," this ANOVA produced a significant overall finding $\mathrm{F}(5 / 416)=6.805, p<.05$. When the Tukey multiple comparison follow-up test was computed, it indicated significant differences in means between the group of Math, Science and Engineering $(M=2.68)$ and the groups Liberal Arts/General Studies $(\mathrm{M}=2.07 ; p=.000)$ and Education $(\mathrm{M}=2.07 ; p=.016)$; and significant differences between the group of Healthcare $(\mathrm{M}=2.67)$ and the groups of Liberal Arts/General Studies $(\mathrm{M}=2.07 ; p=.001)$ and Education $(\mathrm{M}=2.07)$. This finding showed that students who intended to major in Math, Science and Engineering and Healthcare significantly more often expected to "explain understanding of some scientific or mathematical theory, principle or concept to someone else (classmate, co-worker, etc.)" than students who intended to major in Liberal Arts/General Studies and Education.

For the item "SCI4- Read articles about science not assigned," this ANOVA produced a significant overall finding $\mathrm{F}(5 / 417)=4.654, p<.05$. When the Tukey multiple comparison follow-up test was computed, it indicated significant differences in means between the group of Math, Science and Engineering $(\mathrm{M}=2.42)$ and the groups Liberal Arts/General Studies $(\mathrm{M}=1.90$; $p=.001)$ and Education $(\mathrm{M}=1.83 ; p=.033)$. This finding showed that students who intended to major in Math, Science, and Engineering significantly more often expected to "read articles about scientific or mathematical theories or concepts in addition to those assigned for a class" than students who intended to major in Liberal Arts/General Studies and Education. 
Table 52

Means, Standard Deviations, and One-Way Analysis of Variance for the Effects of Academic Major on Quantitative/Scientific Reasoning CSXQ Variables

\begin{tabular}{|c|c|c|c|c|c|c|c|c|c|c|c|c|c|c|c|c|}
\hline \multirow[b]{2}{*}{ Variable } & \multicolumn{2}{|l|}{ MSE } & \multicolumn{2}{|c|}{ BUS/PS } & \multicolumn{2}{|c|}{$\mathrm{LA} / \mathrm{GS}$} & \multicolumn{2}{|c|}{ EDU } & \multicolumn{2}{|l|}{$\mathrm{HE}$} & \multicolumn{2}{|l|}{ PRE } & \multirow[b]{2}{*}{$d f$} & \multirow[b]{2}{*}{$F$} & \multirow[b]{2}{*}{$p$} & \multirow[b]{2}{*}{$\eta^{2}$} \\
\hline & $M$ & $S D$ & $M$ & $S D$ & $M$ & $S D$ & $M$ & $S D$ & $M$ & $S D$ & $M$ & $S D$ & & & & \\
\hline $\begin{array}{l}\text { SCI3- } \\
\text { Explain } \\
\text { scientific } \\
\text { concept to } \\
\text { others }\end{array}$ & 2.68 & .992 & 2.33 & .930 & 2.07 & .844 & 2.07 & .907 & 2.67 & 1.007 & 2.33 & .778 & $5 / 416$ & $6.805^{*}$ & .000 & .000 \\
\hline $\begin{array}{l}\text { SCI4- Read } \\
\text { articles } \\
\text { about } \\
\text { science not } \\
\text { assigned }\end{array}$ & 2.42 & .990 & 2.05 & .899 & 1.90 & .975 & 1.83 & .834 & 2.32 & 1.019 & 2.18 & .751 & $5 / 417$ & $4.654^{*}$ & .000 & .000 \\
\hline
\end{tabular}

Studies. EDU-Education. HE-Healthcare. PRE-Pre-professional. 
In summary, the respondent information gleaned from the survey results represented an ethnically diverse group and traditional age college student population with $90 \%$ of students being age 19 or younger. Almost one-half (45\%) of the sample was first-generation college students, and 99\% were first-time college students beginning their academic studies at MultiCampus Community College.

One-half of the student respondents expected to enroll as a full-time student during the semester. An interesting finding was that although most students respondents (82\%) planned to enroll in between 12 to 17 (or more) credit hours for the semester, that only $12 \%$ of student respondents planned to spend over 21 hours a week on outside of class activities (including studying). Despite the majority (88\%) of respondents expecting to spend 20 hours or less on outside of class preparation, over half ( $58 \%$ ) of students still expected to receive a $\mathrm{B}+$ or higher grade point average.

Similar to the studies of community college student populations by the U.S. Department of Education, student respondents at MCC were most interested in the pursuit of professional degrees in Business (14\%), Healthcare (14\%), and Computer and Information Science (10\%) (Provasnik \& Planty, 2008). With most (86\%) student respondents indicating that they were interested in pursuing advanced degrees, there is most likely an interest amongst respondents in using the community college as an opportunity for transfer to a baccalaureate. 


\section{CHAPTER FIVE}

\section{Summary, Conclusions, and Recommendations}

\section{Overview}

The purpose of this study was to determine first year student expectations of general education goals at a large multi-campus urban community college. The study investigated what general education goals students expected to be emphasized in the community college environment. The study also asked students to share how much effort they expected to apply toward general education goals in the areas of Information Literacy, Communication, Critical Thinking, Cultural and Social Understanding, Quantitative Reasoning, Scientific Reasoning, and Quantitative/Scientific Reasoning. The College Student Expectations Questionnaire (1999) was used to measure environmental emphasis and expectations of community college students enrolled in special Student Development (SDV) courses for first-time college students. This chapter summarizes the results and conclusions from the study. Finally, recommendations for future practice and research are presented based upon significant findings.

\section{Summary of Results}

The first research question examined how much emphasis students believed the community college would place on learning goals. For the first research question, the main findings were:

- Students expected the community college environment to place moderate emphasis on general education goals indicated by the means of the CSXQ College Environment Scales. 
- Student respondents expected more emphasis on developing academic, scholarly, and intellectual qualities $(\mathrm{M}=5.40)$ than emphasis on developing vocational and occupational competence $(\mathrm{M}=4.99)$.

- Students expected the community college to provide the most emphasis on developing information literacy skills $(M=5.47)$ as well as reported an intention to participate the most in college activities that build information literacy skills.

- Items reporting the highest means on the CSXQ College Activity Scales included using "a computer or word processor to prepare reports or papers" $(M=3.54)$ and "Search the World Wide Web or Internet for information related to a course" $(\mathrm{M}=3.34)$.

The second research question examined how much effort students expected to apply toward general education goals. The study also investigated whether significant differences in quality of effort existed based upon Parents’ Education, Employment, College Opinion, and Academic Major (see Tables 53 and 54). For the second research question the main findings were:

- The CSXQ College Activity Scales indicated that most students expected to participate often in activities related to Information Literacy, Communication and Critical Thinking.

- Students expected to occasionally participate in the majority of activities related to Cultural and Social Understanding, Quantitative Reasoning, Scientific Reasoning, and Quantitative/Scientific Reasoning. The lowest means in the quality of effort scales consisted of items in the Cultural and Social Understanding cluster (related to participation in out of class activities) and Scientific Reasoning cluster.

- The analysis of variance (ANOVA) findings revealed significant differences in student expectations by the independent variables: Parents' Education, Employment, College Opinion, and Academic Major (see Tables 53 and 54). 
- The College Opinion variable had the most items with significant differences amongst groups in 32 out of the 35 CSXQ items. It was also the only independent variable with significant differences in group means of items within all seven general education clusters. Post hoc tests revealed significant differences between students who believed that they will be enthusiastic or like college (higher expectations) than students who were neutral/not like college (lower expectations).

- The Academic Major variable had the next highest amount of items with significant differences between groups in 10 out of the 35 CSXQ items that included six out of the seven general education clusters (excluding only Critical Thinking). Most of the significant differences in group means were concentrated in the Quantitative Reasoning, Scientific Reasoning, and Quantitative/Scientific Reasoning clusters. Post hoc tests in these three clusters identified multiple differences between the group means of Math, Science, \& Engineering and Healthcare students (higher expectations) and Liberal Arts/General Studies, Business \& Public Service, and Education students (lower expectations).

- The Parents' Education variable had few significant differences (6 out of 35 items) found amongst the CSXQ variables. The CSXQ items indicating a significant difference were primarily in the Quantitative/Scientific cluster and the Cultural/Social Understanding cluster. Most items with significant differences based on Parents' Education yielded post hoc results with the means of students with both parents as college graduates higher than the means of students with no parents as college graduates. 
- The Employment variable had the least significant differences in means between groups "none," "1 to 20 hours a week," and "21 or more hours a week" occurring in only two CSXQ items. 
Table 53

Total General Education CSXQ Items with Significant Differences in Group Means

\begin{tabular}{|c|c|c|c|c|c|}
\hline $\begin{array}{l}\text { General Education } \\
\text { Goal (Total Number } \\
\text { of CSXQ Items for } \\
\text { Each Goal) }\end{array}$ & $\begin{array}{l}\text { Parents } \\
\text { Education }\end{array}$ & Employment & $\begin{array}{l}\text { College } \\
\text { Opinion }\end{array}$ & $\begin{array}{l}\text { Academic } \\
\text { Major }\end{array}$ & $\begin{array}{l}\text { Total GE Goal } \\
\text { CSXQ Items } \\
\text { with Significant } \\
\text { Differences in } \\
\text { Means }\end{array}$ \\
\hline $\begin{array}{l}\text { Information Literacy } \\
\text { (5) }\end{array}$ & 0 & 0 & 4 & 1 & 5 \\
\hline Communication (4) & 1 & 0 & 3 & 1 & 5 \\
\hline Critical Thinking (5) & 0 & 1 & 5 & 0 & 6 \\
\hline $\begin{array}{l}\text { Cultural/Social } \\
\text { Understanding (14) }\end{array}$ & 2 & 1 & 13 & 1 & 17 \\
\hline $\begin{array}{l}\text { Quantitative } \\
\text { Reasoning (2) }\end{array}$ & 0 & 0 & 2 & 2 & 4 \\
\hline $\begin{array}{l}\text { Scientific Reasoning } \\
\text { (3) }\end{array}$ & 1 & 0 & 3 & 3 & 7 \\
\hline $\begin{array}{l}\text { Quantitative/Scientific } \\
\text { Reasoning (2) }\end{array}$ & 2 & 0 & 2 & 2 & 6 \\
\hline Total & 6 & 2 & 32 & 10 & 50 \\
\hline
\end{tabular}

Note. The total number in the column titled "Total GE Goal CSXQ Items with Significant Differences in Means" may include a repeated variable. 
Table 54

CSXQ General Education Items Indicating Significant Differences or Strong Trends in Group Means Based on Parents' Education, Employment, College Opinion and Academic Major

\begin{tabular}{|c|c|c|c|c|c|c|}
\hline CSXQ Item & Parents' Education & Employment & College Opinion & & \multicolumn{2}{|l|}{$\begin{array}{l}\text { Academic } \\
\text { Major }\end{array}$} \\
\hline & Groups & Groups & Groups & & \multicolumn{2}{|l|}{ Groups } \\
\hline \multicolumn{7}{|l|}{ Information Literacy } \\
\hline \multirow[t]{2}{*}{$\begin{array}{l}\text { Use of an index or database (computer, card catalog, etc.) to find } \\
\text { material on some topic }\end{array}$} & & & $\begin{array}{l}\text { Not Like/Neutral } \\
\text { Enthusiastic }\end{array}$ & * & & \\
\hline & & & $\begin{array}{l}\text { Not Like/Neutral } \\
\text { Like }\end{array}$ & $*$ & & \\
\hline Use a computer or word processor to prepare reports or papers & & & $\begin{array}{l}\text { Not Like/Neutral } \\
\text { Like }\end{array}$ & $*$ & & \\
\hline \multirow[t]{2}{*}{$\begin{array}{l}\text { Prepare a paper or project where you had to integrate ideas from } \\
\text { various sources }\end{array}$} & & & $\begin{array}{l}\text { Not Like/Neutral } \\
\text { Enthusiastic }\end{array}$ & $*$ & & \\
\hline & & & $\begin{array}{l}\text { Not Like/Neutral } \\
\text { Like }\end{array}$ & $*$ & & \\
\hline \multirow[t]{4}{*}{ Computers and other technologies } & & & $\begin{array}{l}\text { Not Like/Neutral } \\
\text { Enthusiastic }\end{array}$ & $*$ & $\begin{array}{l}\text { MSE } \\
\text { BUS/PS }\end{array}$ & $*$ \\
\hline & & & & & $\begin{array}{l}\text { MSE } \\
\text { LA/GS }\end{array}$ & $*$ \\
\hline & & & & & $\begin{array}{l}\text { MSE } \\
\text { EDU }\end{array}$ & \\
\hline & & & $\begin{array}{l}\text { Like } \\
\text { Enthusiastic }\end{array}$ & $*$ & & \\
\hline \multicolumn{7}{|l|}{ Communication } \\
\hline \multirow[t]{3}{*}{ Contribute to class discussions } & & & $\begin{array}{l}\text { Not Like/Neutral } \\
\text { Like }\end{array}$ & $*$ & & \\
\hline & & & $\begin{array}{l}\text { Not Like/Neutral } \\
\text { Enthusiastic }\end{array}$ & $*$ & & \\
\hline & & & $\begin{array}{l}\text { Like } \\
\text { Enthusiastic }\end{array}$ & $*$ & & \\
\hline
\end{tabular}


Table 54 (continued)

CSXQ General Education Items Indicating Significant Differences or Strong Trends in Group Means Based on Parents' Education, Employment, College Opinion and Academic Major

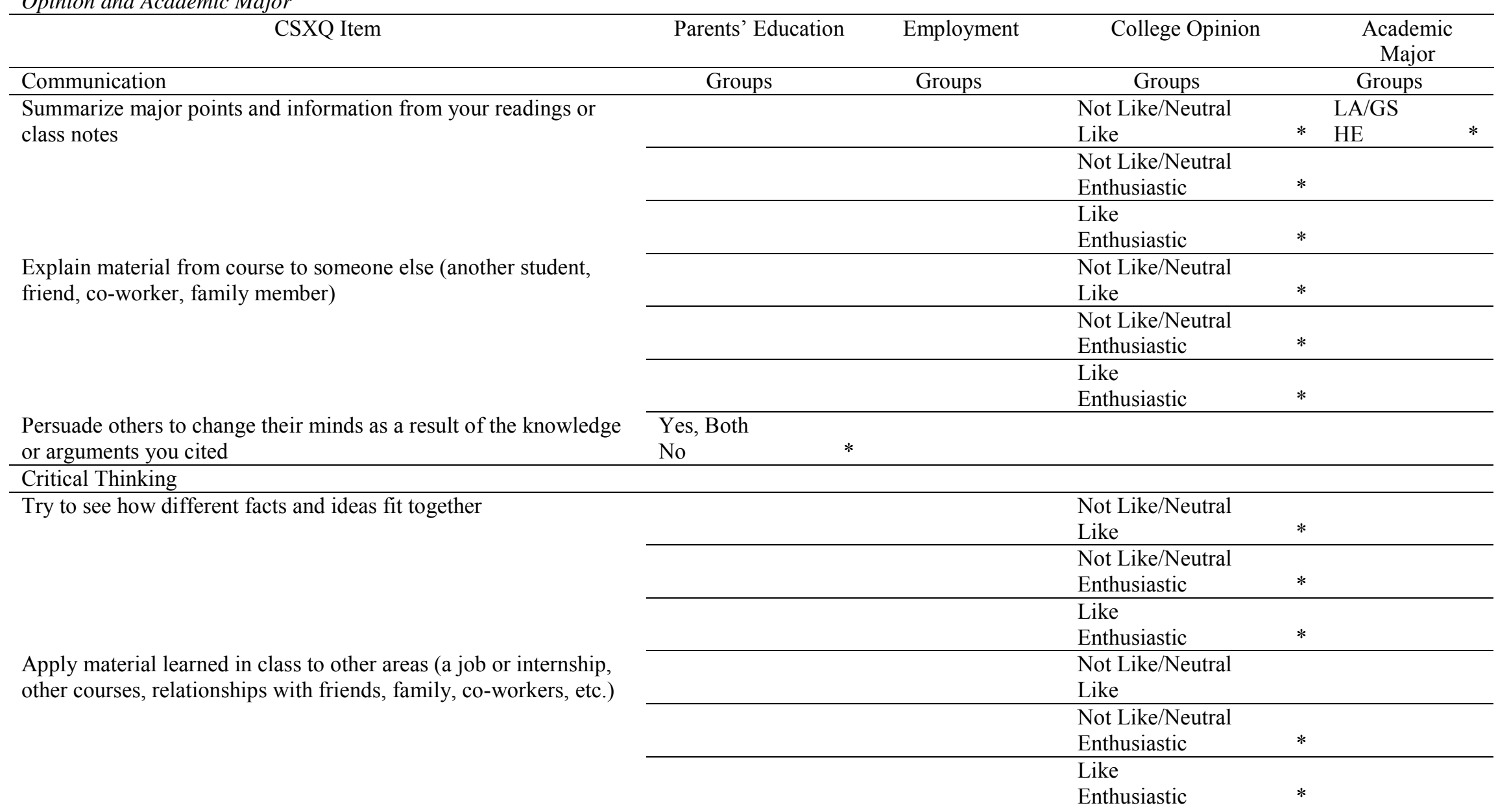


Table 54 (continued)

CSXQ General Education Items Indicating Significant Differences or Strong Trends in Group Means Based on Parents' Education, Employment, College Opinion and Academic Major

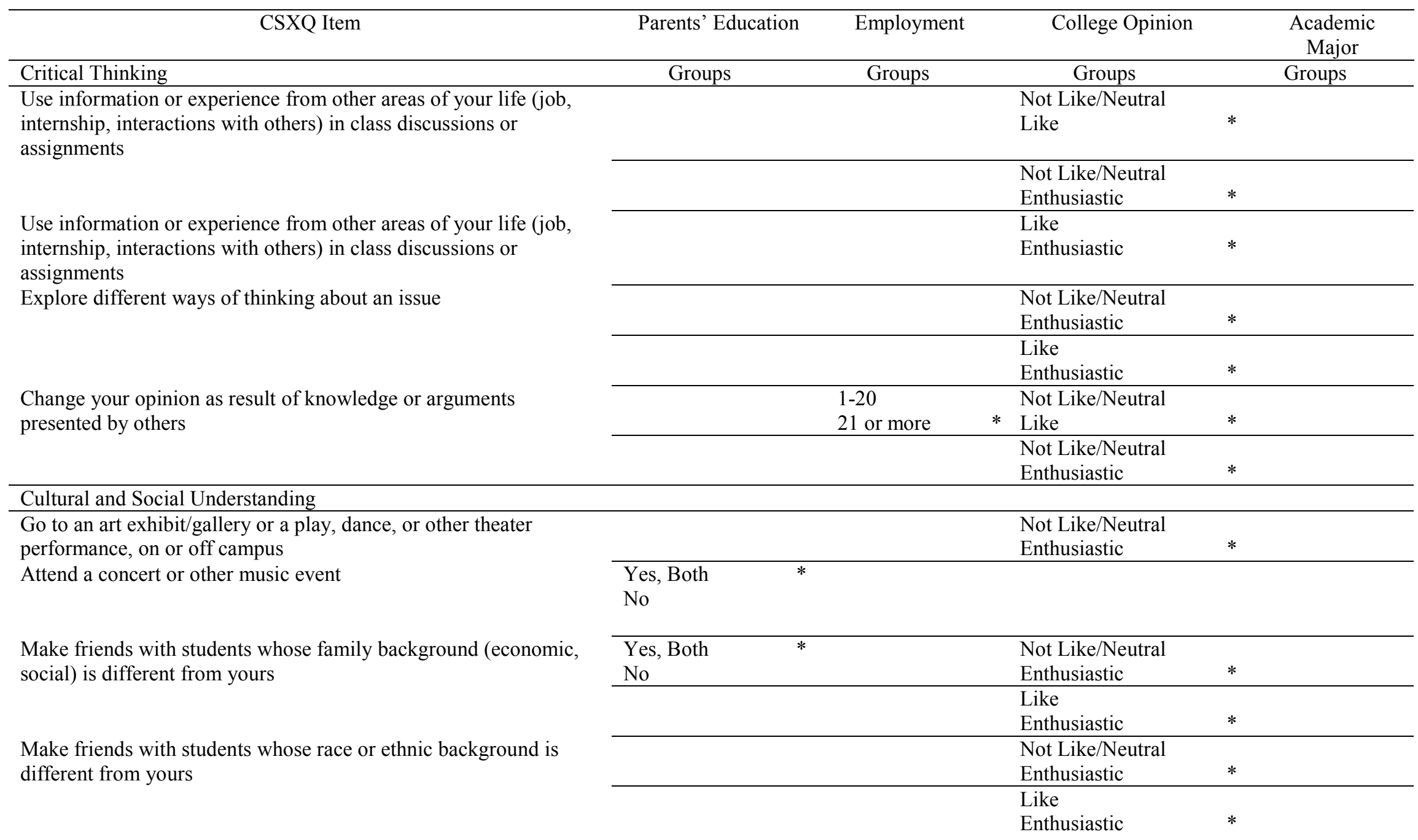


Table 54 (continued)

CSXQ General Education Items Indicating Significant Differences or Strong Trends in Group Means Based on Parents' Education, Employment, College Opinion and Academic Major

\begin{tabular}{|c|c|c|c|c|}
\hline CSXQ Item & Parents' Education & Employment & College Opinion & $\begin{array}{l}\text { Academic } \\
\text { Major }\end{array}$ \\
\hline Cultural and Social Understanding & Groups & Groups & Groups & Groups \\
\hline \multirow[t]{2}{*}{$\begin{array}{l}\text { Have serious discussions with students whose philosophy of life or } \\
\text { personal values are very different from yours }\end{array}$} & & & $\begin{array}{l}\text { Not Like/Neutral } \\
\text { Enthusiastic }\end{array}$ & * \\
\hline & & & $\begin{array}{l}\text { Like } \\
\text { Enthusiastic }\end{array}$ & * \\
\hline \multirow[t]{2}{*}{$\begin{array}{l}\text { Have serious discussions with students whose religious beliefs are } \\
\text { very different from yours }\end{array}$} & & & $\begin{array}{l}\text { Not Like/Neutral } \\
\text { Enthusiastic }\end{array}$ & $*$ \\
\hline & & & $\begin{array}{l}\text { Like } \\
\text { Enthusiastic }\end{array}$ & * \\
\hline \multirow[t]{2}{*}{$\begin{array}{l}\text { Have serious discussions with students whose political opinions are } \\
\text { very different from yours }\end{array}$} & & & $\begin{array}{l}\text { Not Like/Neutral } \\
\text { Enthusiastic }\end{array}$ & $*$ \\
\hline & & & $\begin{array}{l}\text { Like } \\
\text { Enthusiastic }\end{array}$ & * \\
\hline \multirow[t]{2}{*}{$\begin{array}{l}\text { Have serious discussions with students whose race or ethnic } \\
\text { identification is very different from yours }\end{array}$} & & & $\begin{array}{l}\text { Not Like/Neutral } \\
\text { Enthusiastic }\end{array}$ & $*$ \\
\hline & & & $\begin{array}{l}\text { Like } \\
\text { Enthusiastic }\end{array}$ & $*$ \\
\hline \multirow[t]{2}{*}{$\begin{array}{l}\text { Social issues such as peace, justice, human rights, equality, race } \\
\text { relations }\end{array}$} & & $\begin{array}{l}\text { None } \\
21 \text { or more }\end{array}$ & $*$ & \\
\hline & & $\begin{array}{l}1-20 \\
21 \text { or more }\end{array}$ & $*$ & \\
\hline \multirow[t]{3}{*}{ Different lifestyles, customs, and religions } & & & $\begin{array}{l}\text { Not Like/Neutral } \\
\text { Like }\end{array}$ & $*$ \\
\hline & & & $\begin{array}{l}\text { Not Like/Neutral } \\
\text { Enthusiastic }\end{array}$ & $*$ \\
\hline & & & $\begin{array}{l}\text { Like } \\
\text { Enthusiastic }\end{array}$ & $*$ \\
\hline
\end{tabular}


Table 54 (continued)

CSXQ General Education Items Indicating Significant Differences or Strong Trends in Group Means Based on Parents’ Education, Employment, College

Opinion, and Academic Major

\begin{tabular}{|c|c|c|c|c|c|c|}
\hline CSXQ Item & Parents' Education & Employment & College Opinion & & \multicolumn{2}{|l|}{$\begin{array}{l}\text { Academic } \\
\text { Major }\end{array}$} \\
\hline & Groups & Groups & Groups & \multicolumn{3}{|c|}{ Groups } \\
\hline The ideas and views of writers, philosophers, historians & & & $\begin{array}{l}\text { Not Like/Neutral } \\
\text { Enthusiastic }\end{array}$ & * & & \\
\hline \multirow{4}{*}{$\begin{array}{l}\text { The arts (painting, poetry, theatrical productions, dance, symphony, } \\
\text { movies, etc.) } \\
\text { The economy (employment, wealth, poverty, debt, trade, etc.) }\end{array}$} & & & $\begin{array}{l}\text { Like } \\
\text { Enthusiastic }\end{array}$ & * & & \\
\hline & & & $\begin{array}{l}\text { Not Like/Neutral } \\
\text { Enthusiastic }\end{array}$ & * & $\begin{array}{l}\text { LA/GS } \\
\text { BUS/PUS }\end{array}$ & * \\
\hline & & & $\begin{array}{l}\text { Not Like/Neutral } \\
\text { Like }\end{array}$ & * & & \\
\hline & & & $\begin{array}{l}\text { Not Like/Neutral } \\
\text { Enthusiastic }\end{array}$ & * & & \\
\hline \multirow{3}{*}{$\begin{array}{l}\text { International relations (human rights, free trade, military activities, } \\
\text { political differences, etc.) }\end{array}$} & & & $\begin{array}{l}\text { Like } \\
\text { Enthusiastic }\end{array}$ & * & & \\
\hline & & & $\begin{array}{l}\text { Not Like/Neutral } \\
\text { Enthusiastic }\end{array}$ & * & & \\
\hline & & & $\begin{array}{l}\text { Like } \\
\text { Enthusiastic }\end{array}$ & * & & \\
\hline \multicolumn{7}{|l|}{ Quantitative Reasoning } \\
\hline \multirow[t]{2}{*}{ Memorize formulas, definitions, technical terms and concepts } & & & $\begin{array}{l}\text { Not Like/Neutral } \\
\text { Enthusiastic }\end{array}$ & * & $\begin{array}{l}\text { MSE } \\
\text { LA/GS }\end{array}$ & * \\
\hline & & & & & $\begin{array}{l}\mathrm{LA} / \mathrm{GS} \\
\mathrm{HE}\end{array}$ & * \\
\hline \multirow[t]{3}{*}{ Express a set of relationships using mathematical terms } & & & $\begin{array}{l}\text { Not Like/Neutral } \\
\text { Enthusiastic }\end{array}$ & * & $\begin{array}{l}\text { LA/GS } \\
\mathrm{HE}\end{array}$ & * \\
\hline & & & & & $\begin{array}{l}\mathrm{MSE} \\
\mathrm{LA} / \mathrm{GS}\end{array}$ & * \\
\hline & & & & & $\begin{array}{l}\text { MSE } \\
\text { BUS/PS }\end{array}$ & $*$ \\
\hline
\end{tabular}


Table 54 (continued)

CSXQ General Education Items Indicating Significant Differences or Strong Trends in Group Means Based on Parents' Education, Employment, College

Opinion and Academic Major

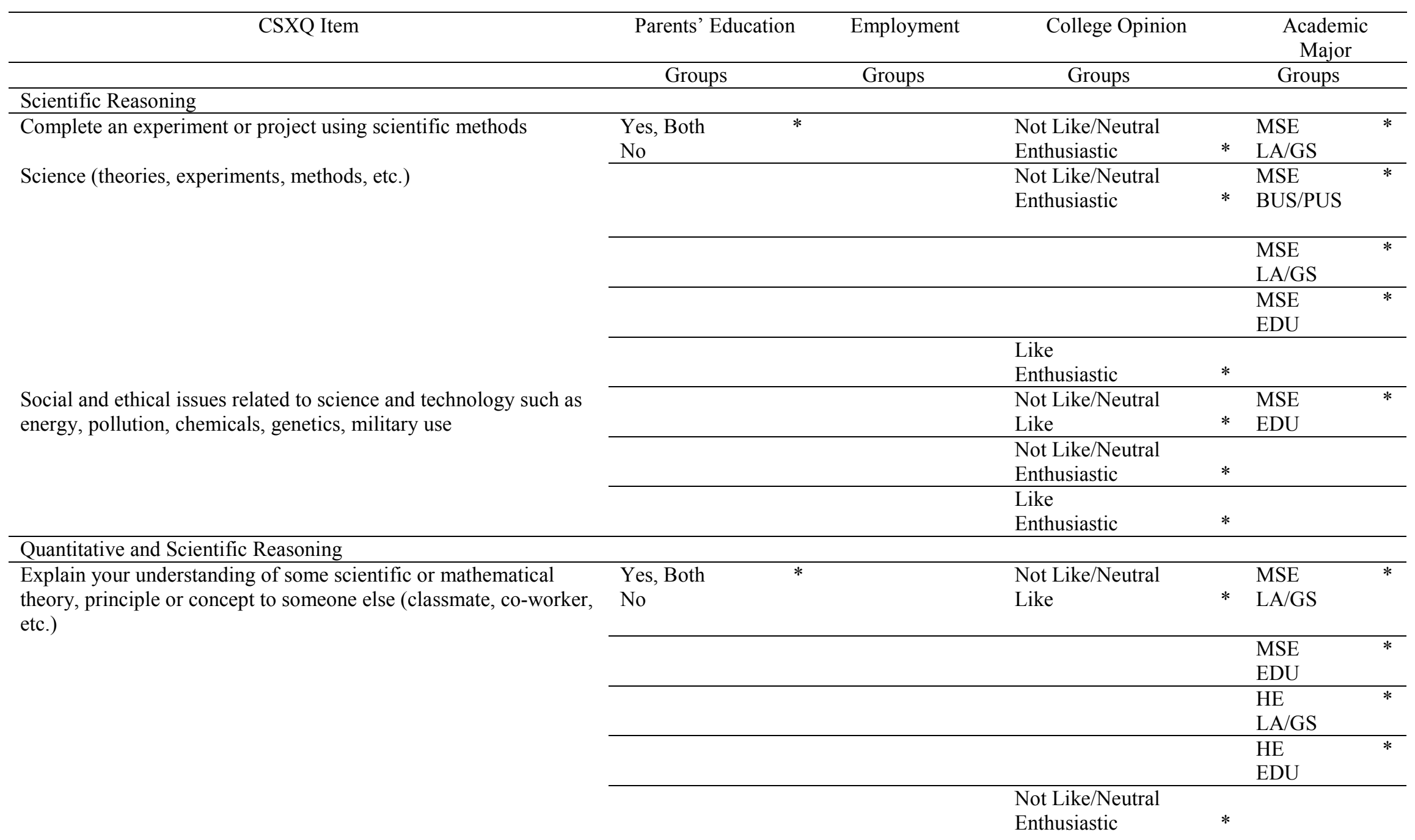


Table 54 (continued)

CSXQ General Education Items Indicating Significant Differences or Strong Trends in Group Means Based on Parents' Education, Employment, College

Opinion and Academic Major

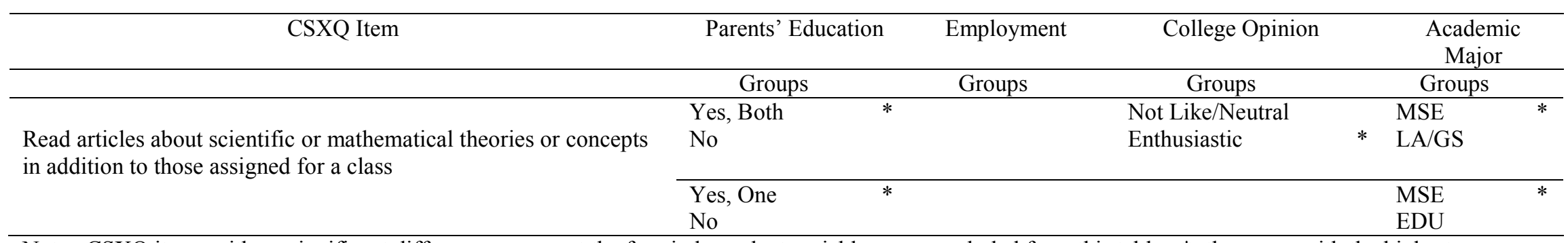

Note. CSXQ items with no significant differences amongst the four independent variables were excluded from this table. ${ }^{*}=$ the group with the highest mean. Remaining groups have significant differences/strong trends with the group identified by the * symbol. MSE-Math, Science and Engineering. BUS/PS-Business and Public Services. LA/GS-Liberal Arts/General Studies. EDU-Education. HE-Healthcare. PRE-Pre-professional. 


\section{Conclusions}

\section{Environmental Emphasis}

Student respondents believed that their community college environment would provide a moderate to strong emphasis upon learning goals. Considering the history of community colleges and the expectations of students to expect training in job skills, a surprising finding was that most students expected the community college to provide more emphasis developing academic, scholarly, and intellectual qualities than on developing vocational and occupational competence. Previous research on student expectations discussed that students attend community college because they view the institution as a place to develop job skills (Horn \& Griffith, 2006; Provasnik \& Planty, 2008). Therefore, the results of this study reveal that MCC students may have a better understanding that the academic, scholarly, and intellectual skills are contributory to their intended professional careers.

The majority of respondents particpating in this study were transfer-oriented students. Most students intended to major in professional fields with Healthcare, Business, and Computer and Information Sciences having the highest interest. Therefore, participants may have believed (to their satisfaction or disatisfaction) that the community college will emphasize less the vocational and occupational competence. They may anticipate that this emphasis will be stronger after transfer to a university when they are able to take more courses in their major.

\section{Information Literacy}

Gratch-Lindauer (2008) found a positive correlation between engagement in information literacy and practical competence. In this study, respondents believed the community college would emphasize information literary skills more than the other seven learning goals. Concurrently, students most expected to participate in activities which developed information 
literacy skills more than all other activities. As information literacy skills will have an impact on both academic and professional success of current students and graduates, it appears as if the respondents expected to be provided opportunities to develop as well as utilize these skills at the community college.

\section{Cultural and Social Understanding}

The Cultural and Social Understanding cluster consisted of items relating to attending events, discussions with certain groups, and conversations about various topics. Students expected to often participate in activities pertaining to engaging in discussions with individuals from different: family backgrounds, race/ethnic backgrounds, and philosophies or values. Students also expected to often converse about different lifestyles, customs, and religion. However, students expected to only occasionally participate in activities which included attending cultural and social events (exhibits, performances, concerts, etc.).

Students believed the community college would provide an emphasis on developing an understanding and appreciation of human diversity. Therefore, the student respondents are most likely expecting growth in this area from academic learning and social interactions with students in the classroom or through acquaintances. As Green and Siaya (2005) contended that community colleges have difficulty in achieving goals for international literacy in the curriculum, students may more often have opportunities to develop these skills with class discussions and social interactions amongst students in the classroom settings. A significant challenge of student activity programming for community college students is that their nonresidential/commuter status provides barriers for attendance in out-of-class activities. However, MCC has a very diverse racial/ethnic student population which would provide those opportunities for cross-cultural and social exchange inside of the classroom. 


\section{Quantitative and Scientific Reasoning}

The findings in the categories related to Quantitative and Scientific Reasoning supports previous research that students are intimidated by mathematics and science (Ramaley \& Haggett, 2005; Bluestone, 2007). The college activities in Qualitative Reasoning, Scientific Reasoning and Quantitative/Scientific Reasoning students only expected to do occasionally with the exception of memorizing formulas, definitions, and concepts (Quantitative Reasoning) where students expected to do often. Significant differences based upon Parents' Education, College Opinion, and Academic Major was found within all three general education clusters.

Parents' education. The educational attainment of parents had a significant effect on the expected quality of effort in activities related to quantitative and scientific reasoning. Students who had one or both parents that attended college consistently expected to participate more in quantitative and scientific reasoning activities more than students who were first generation college students. Significant differences were found amongst both items in the quantitative/scientific reasoning cluster and one item (out of two items) in the scientific reasoning cluster between students who had both parents graduate from college and students who had no parent graduate from college.

Academic major. Students who major in Math, Science and Engineering and Healthcare more often expected to participate in Quantitative and Scientific Reasoning activities than other majors. Liberal Arts/General Studies and Education majors consistently had lower expectations to participate in these activities. Although it may be understandable that students in Science and Healthcare majors would expect to become involved in these learning activities more often, the Liberal Arts/General Studies and Education students only expected to engage in these activities involving critical thinking, application, reading, and discussing science/mathematics 
occasionally. The only activity that all majors expected to do often was related to memorization of formulas, facts, and concepts.

\section{College Opinion}

This study's most significant finding was the impact of community college students' opinion of college on their quality of effort in activities that develop general education goals. In 32 out of 35 college activities, students who were neutral or did not like college expected to exert less quality of effort than students who liked or were enthusiastic about college. All activities in Critical Thinking, Quantitative Reasoning, Scientific Reasoning, and Quantitative/Scientific Reasoning had significant differences between groups. All but one activity in Information Literacy, Communication, and Cultural and Social Understanding also had significant differences between groups.

Pace's Quality of Effort Theory $(1979,1984)$ identifies entrance measures which are subject to change as a result of college experiences: knowledge, critical thinking, interests, values, and personal traits. Students' expected opinion of college (whether they believe they will be enthusiastic, like, neutral or not like college) in this study appeared to be very strong indicator of potential quality of effort in the academic year. The enthusiasm of attending college proved to have a significant effect on having higher expectations for engaging in college experiences that develop general education learning outcomes.

\section{Recommendations for Practice}

\section{Enhancing College Marketing Materials}

The first recommendation for practice is to enhance marketing materials to communicate expectations and share with prospective students what learning goals will be emphasized at community colleges. Marketing resources including admissions materials, commercials (radio 
and television) should provide information to students about essential learning outcomes. Admissions counselors and recruiters can also make an effort to articulate this message to prospective student and parent audiences. Just a basic explanation would not provide motivation for student engagement; therefore, community colleges should also connect learning outcomes to knowledge/skills needed for transfer to the baccalaureate and future employment. As recent literature has demonstrated the types of college graduates they wish to hire, marketing and recruitment can be enhanced to give prospective students the message that the community college will provide opportunities for the development of skills beyond technical expertise. Materials used for matriculating college students (i.e. academic catalog, college website, and advising materials) can also be enhanced for continuing communication of the importance of essential college outcomes throughout students' academic careers.

\section{Coordinating First Year Experience Programs}

The second recommendation for practice is to require all first-time/degree-seeking students to participate in some form of First Year Experience (FYE) programming prior to registering for courses. FYE programs at colleges may include new student orientation, first year advising, convocation, first year seminar courses, and/or specialized student activity events for first-time college students. All of the initiatives are opportunities to increase engagement opportunities for new students with current students, faculty and staff. Therefore, they provide the chance to communicate the college's expectations for learning and more importantly describe how the learning goals are to be realized (through study in general education courses and major courses, participation in student activities, etc.).

Tinto $(1975,1987,1993)$ emphasized in his theory the importance of academic and social integration of college students and its impact on students' decision to withdraw. With 
community college students, both academic and social integration experiences appear to go hand in hand as a commuter student population. Therefore, First Year Experience programs such as new student orientations, first year seminar courses, and learning communities provide students with the chances to learn more about the general education goals of the college and the general education curriculum which they will study in order to complete their degree. It provides an opportunity to answer students' questions and also to make connections between goals and the curriculum. FYE programs are also important to encourage students to participate in out-of-class activities and also promote ways in which they can engage in the campus community with students from different backgrounds for additional learning experiences.

With the findings of this study indicating a strong connection between college opinion and quality of effort, FYE programs can attempt to improve students' attitudes towards attending community college early. We understand that all students are not excited about attending community college because for some students it was not their first choice institution. Due to financial constraints, inability to become accepted at a preferred university, or need for developmental education, some students chose to attend community college to transition to a university as quickly as possible. Therefore, they arrive at the community college with a neutral or negative opinion and are sometimes embarrassed that they did not begin at a university with peers. Exciting and engaging FYE programs which address students' interests and how the community college can assist with their goals (including transfer) may incite more enthusiasm about enrolling and exerting more effort towards learning goals. FYE programs at the community college are typically retention initiatives to encourage students to complete the associate's degree and/or certificate; however, there has to be an acknowledgement that some students are planning for early transfer which is also an indicator of student success. 
A challenge which remains is that some community colleges are still very reluctant to make programs such as new student orientation mandatory prior to registration for the fear of negatively affecting enrollment. Consequently, the enthusiastic students or students who expect to like college may already be inclined to attend and participate in FYE events. Unfortunately, the students who are neutral or expect to not like college will most likely decline to participate when provided with an option for attendance in FYE programming (particularly students without strong parental encouragement).

\section{Enhancing Academic Advising Services}

The third recommendation for practice is to enhance academic advising at the community college to help students make connections between their general education courses and the general education learning goals. Also, it is recommended that advisors communicate the importance of knowledge and skills learned through the study of general education to areas that interest students such as study in the academic major, transfer, and employment.

In this study, the expectation to just occasionally participate in college activities that develop general education goals may be a result of students viewing these activities as a barrier or peripheral to their career/vocational interests (especially students who expect to be neutral or not to like college). As successful completion of general education courses is mandatory for successful completion of a degree, the guidance of an advisor, counselor, or faculty member in the selection of courses is a key element in student retention. As community colleges generally follow the distribution model of general education, helping students make informed choices in the selection of courses to meet occupational/vocational or personal interests is recommended. It is also equally important to help students identify the knowledge and skills they will receive as a result of their studies in general education. 
As students will often inquire, "Why do I have to take this course?" advisors/counselors should be able to provide students with an explanation as to how study in English, Speech, Humanities/Fine Arts, Social Sciences, and Natural Sciences will help students develop skills needed for transfer and their professional careers. Advisors/counselors should also be able to help students find connections between courses in the distribution list and their academic major. For example, the students in this study majoring in Education reported a low quality of effort on items related to quantitative and scientific reasoning. However, students who pursue careers in teaching will eventually be assessed in these areas with graduate school admissions tests or state assessments for teacher licensure. In their professional careers, they will also be responsible for teaching these same skills to their future pupils (particularly if they are interested in elementary education).

\section{Making Science and Mathematics Relevant}

The final recommendation for practice calls for the inclusion of quantitative and scientific literacy courses in the general education distribution of community colleges and the initiation of transfer of these courses to the baccalaureate. It is also recommended that faculty help students to see the relevancy of mathematics and science in their academic, professional and personal lives.

Understanding the intimidation of students enrolling in mathematics and natural/physical science courses and the offering of "plain vanilla" courses (repetitive of the same topics in secondary school), community colleges should consider quantitative and scientific literacy courses that make connections between the disciplines and real-life application. The challenge would be overcoming the issue of "transferability". Community colleges would have to 
simultaneously collaborate with universities to develop these courses and ensure that students could use them to meet general education requirements after transfer.

As processes dealing with academic reform and initiating transfer agreements can become lengthy, instructors can immediately consider adopting pedagogy that demonstrates the utility of mathematics and science in their current courses. Creating learning communities and connecting with other disciplines will provide additional opportunities for students to demonstrate the real world application of science and mathematics as future professionals and citizens. Also academic advisors/counselors and faculty communicating to students the transferable skills (critical thinking, research, etc.) developed from study in these disciplines will provide them with a perspective of why these courses are included in their general education curriculum.

\section{Recommendations for Research}

\section{Investigating Significant Differences by Race and Ethnicity}

The first recommendation for research is to conduct a similar study with the College Student Expectations Questionnaire (1999) and see if there are significant differences in students' expectation toward general education goals by race/ethnicity. This study was inclusive of a very diverse racial/ethnic population. Understanding the concerns for the retention of ethnic minorities in community college, it would be an interesting finding to understand their expectations of college as first-time college students. It would also be useful to make comparisons with students who identify themselves as Caucasian and also compare the outcomes of the survey amongst different minority groups (Asian, Black/African American and Hispanic).

In addition, it would be valuable information to understand if there are differences in college opinion based upon race/ethnicity and gender of participants. For instance if 
Black/African American and Hispanic expected to be neutral or not like college significantly more than Asian and Caucasian males, then additional qualitative research could be done with students to investigate reasons behind their lowered expectations.

\section{Conducting Qualitative Research on College Opinion}

The second recommendation for research is to investigate further what factors affect students' positive opinion of college. In study, students were able to report whether they believed they would be enthusiastic, like, neutral, or not like college. Over one quarter (27.3\%) reported that they would be neutral or not like college. The nearly one half (46.5\%) of student respondents believed that they would like college. The remainder of student respondents (26.1\%) felt as if they would be very enthusiastic about attending college.

What the survey is not designed to explain is why students have formulated their opinions at the beginning of their studies. A qualitative research study could determine whether students' neutral or negative opinion could be attributed to college selection, finances, employment constraints, negative family opinion, placement into development education, or other factors. It could also investigate why students anticipate being enthusiastic about attending a community college. Are they happy they are closer to home and family? Relieved about cost savings? Interested in transfer opportunities? Are students eager to study high-demand professional programs (i.e., healthcare)?

A research study can also investigate which best practices affect first-time community college students' positive opinion of college. It could be that a student was initially neutral and due to his/her attendance at a new student orientation program changed his/her opinion. Therefore, initiatives that target prospective students (open houses, high school visits, etc.), preenrolled students (orientation, advising, etc.) and enrolled students (convocation, first year 
experience programming, freshman seminar, etc.) could be studied to see which ones have a greater affect on student opinion of college after their first semester of attendance.

Quality of effort can also be measured as well to compare if students who expect to be enthusiastic or like college participated in first year student advising and programming to students who anticipated being neutral or like college. This information can help provide data indicating that unless certain activities are mandated, community colleges may not reach the population in most need of student development programming (students with negative opinion and lower expectations).

\section{Studying the Quality of Effort of Adult Community College Students}

The third recommendation for research would be to investigate whether significant differences exist in the expected quality of effort toward general education goals between traditional and non-traditional college aged students. The researcher did not find significant differences in expected quality of effort based upon off campus employment in this study. A possible explanation could be that the majority of students were first-time and traditional aged college students $(90 \%$ were 19 or younger). Students were most likely recent high school graduates.

Therefore, more adults over the age of 23 included in a similar study could allow for a comparison between the two groups (traditional and non-traditional aged students). Also the inclusion of working adult students could affect variable of Employment. It could be investigated whether students who work full-time off campus will expect to exert less quality of effort towards learning goals than students who plan to only work part-time off-campus. This information would be useful because it would provide insight as to whether adult independent 
students' quality of effort is sacrificed as a result of balancing multiple responsibilities (work, home, family, finances, etc.).

\section{Investigating Community College Student Expectations and Experiences}

A fourth recommendation for research would be to measure whether there were differences in community college student expectations versus their actual experiences. Earlier literature suggested that students saw the importance of learning outcomes and related activities; however, they experienced a disconnection between learning goals and their experiences in the classroom and college environment. The College Student Expectations Questionnaire (1999) and the College Student Experiences Questionnaire (1998) have been used as pretest and posttest to measure expected quality of effort at the beginning of the semester with the reported quality of effort at the end of the semester or academic year.

\section{Conducting Qualitative Research on General Education in Community Colleges}

The final recommendation for research would be to use qualitative research methods to study community college student experiences and general education. There is still a lack of research explaining whether community college students believe they have received the opportunity to develop and achieve competences in essential learning outcomes through study in the general education curriculum. A qualitative study at community colleges would be appropriate using interviews and focus groups to investigate whether: (1) students see a connection between learning outcomes and the general education curriculum, (2) students value essential learning outcomes, (3) faculty or classroom experiences have affected their opinion of general education, and (4) if students perceive general education courses as a barrier to their academic major or professional career. 


\section{References}

Anderson, M. W., Teisi, M., Criner, G., Tisher, S., Smith, S., Hunter, M., et al. (2007). Attitude changes of undergraduate university students in general education courses. The Journal of General Education, 56(2), 149-168.

Association of American Colleges and Universities. (2007). College learning for the new global century report. Washington, DC.

Association of American Colleges and Universities. (2002). Greater expectations: A new vision for learning as a nation goes to college. Washington, D.C.

Association of College and Research Libraries. (2000). Information literacy competency standards for higher education. Chicago, IL: American Library Association.

Attinasi, L., \& Nora, A. (1992). Diverse students and complex issues: A case for multiple methods in college research. In F. Stage (Ed.), Diverse methods for research and assessment (pp. 13-28). Alexandria, VA: American College Personel Association.

Bean, J., \& Metzner, B. (1985). A conceptual model of nontraditional undergraduate student attrition. Review of Educational Research, 55(4), 485-540.

Berger, J. B., \& Braxton, J. M. (1998). Revising Tinto's interactionalist theory of student departure through theory elaboration: Examining the role of organizational attributes in the persistence process. Research in Higher Education, 39(2), 103-118.

Bers, T. (2005). Assessing critical thinking in community college. New Directions for Community Colleges, (130), 15-25.

Bers, T., \& Smith, K. (1991). Persistence of community college students: The influence on student intent and academic and social integration. Research in Higher Education , 32 (5), 529-556. 
Bluestone, C. (2007). Infusing active learning into research methods unit. College Teaching , 55 (3), 91-95.

Braxton, J. M., Hirschy, A., \& McClendon, S. (2004). Toward understanding and reducing college student departure: ASHE-ERIC Higher Education Report (Vol. 30). San Francisco: Jossey-Bass.

Braxton, J., Sullivan, A., \& Johnson, R. (1997). Appraising Tinto's theory of college student departure. In J. Smart (Ed.), Higher education: Handbook of theory and research (pp. 107-164). New York: Agathon.

Brookfield, S. D. (2005). Overcoming impostorship, cultural suicide, and lost innocence: Implications for teaching critical thinking in community college. New Directions for Community College (130), 49-57.

Byrd Murphy, M. (2008). Students' perceptions of academic experiences related to student retention at community colleges (Doctoral dissertation). Retrieved from ProQuest, UMI Dissertations Publishing (3334637).

Cabrera, A., Castaneda, M., Nora, A., \& Hengler, D. (1992). The convergence between the two theories of college persistence. Journal of Higher Education , 63(2), 143-164.

Cejda, B., \& Kaylor, A. (2001). Early transfer: A case study of traditional aged community college students. Community College Journal of Research and Practice, 25(8), 621-638.

Cohen, A., \& Brawer, F. (2008). The american community college (5th ed.). San Francisco: Jossey-Bass.

Cox, R. (2009). I would have rather paid for a class I wanted to take: Utilitarian approaches to a community college. The Review of Higher Education , 32(3), 353-382. 
Dallinger, J., \& Mann, K. (2000). Assessing student knowledge of and attitudes towards the humanities. College Teaching , 48(3), 95-102.

Dietz, T. L. (2006). The effect of data analysis modules in the introductory sociology course: Lessons for the social sciences. Innovative Higher Education, 31(1), 27-42.

Dunbar, N. E., Brooks, C. F., \& Kubicka-Miller, T. (2006). Oral communication skills in higher education: Using a performance-based rubric to assess communication skills. Innovative Higher Education , 31(2).

Durkheim, E. (1951). Suicide: A study in sociology. New York: Free Press.

Engleberg, I. N., Emanuel, R. C., Van Horn, T., \& Bodary, D. L. (2008). Communication education in U.S. community colleges. Communication Education , 57(2), 241-265.

George, L. A. (2010, March/April). Increasing scientific literacy about global climate change through a laboratory-based feminist science course. Journal of College Science Teaching, 39(4), 28-34.

Glanzer, P. L., Ream, T. C., Villarreal, P., \& Davis, E. (2004). The teaching of ethics in christian higher education: An examination of general education requirements. The Journal of General Education, 53(3-4), 184-200.

Gratch-Lindauer, B. (2008). College student engagement surveys: Implications for information literacy. New Directions for Teaching and Learning, (14), 101-114.

Green, M., \& Siaya, L. (2005). Measuring internalization at community colleges. Washington, D.C.: American Council on Education.

Halpin, R. (1990). An application of the Tinto model to the analysis of freshman persistence in a community college. Community College Review, 17(4), 22-32. 
Halx, M. D., \& Reybold, L. E. (2005). A pedagogy of force: Faculty perspectives of critical thinking capacity in undergraduate students. The Journal of General Education , 54(4), 293-315.

Hammer, C., \& Dusek, V. (2006). The rationale and challenge for the intergration of science studies in the revision of general education curricula. The Journal of General Education, 55(1), 1-16.

Harmes, J. C., \& Miller, B. (2007). What do college students think about general education and assessment? Rocky Hill, CT: Paper presented at the annual meeting of the Northeastern Educational Research Association.

Hart Research Associates. (2004). Key findings among the focus groups of college students and college-bound high school seniors. Washington, DC: Association of American Colleges and Universities.

Hart Research Associates. (2005). Key findings from focus groups of college students and college-bound high school students in Wisconsin. Washington, DC: Association of American Colleges and Universities.

Hart Research Associates. (2006). Report of findings based on focus groups of business executives. Washington, DC: American Association of Colleges and Universities.

Hart Research Associates. (2009). Learning and assessment: Trends in undergraduate education. Washington, DC: The Association of American Colleges and Universities.

Hart Research Associates. (2010). Raising the bar: Employers' views on college learning in the wake of the economic downturn. Washington, DC: The Association of American Colleges and Universities. 
Hastings, A., Arzberger, P. B., Collins, S., Ives, A. R., Johnson, N. A., \& Palmer, M. (2005). Quantitative bioscience for the 21st century. Bioscience, 55(6), 511-517.

Hennessey, D. (2005). Reforming writing among students in community colleges. Community College Journal of Research and Practice, 29(4), 261-275.

Higginbottom, G. H., \& Romano, R. M. (2006). Appraising the efficacy of civic education at the community college. New Directions for Community College, (136), 23-32.

Hill, C. (2007). Using popular culture to teach quantitative reasoning. PRIMUS , XVII(1), 36-43.

Hodge, G., Lewis, T., Kramer, K., \& Hughes, R. (2001). Collaboration for excellence: Engaged scholarship at Collin County Communty College. Community College Journal of Research and Practice, 25(9), 675-690.

Horn, L., \& Griffith, J. (2006). Profile of undergraduates in U.S. postsecondary education institutions: 2003-04: With a special analysis of community college students (NCES 2006-184). Washington, DC: National Center for Education Statistics, Institute of Education Sciences, U.S. Department of Education.

House, J. D. (2006). Using the college student survey to assess student perceptions and achievement. Assessment Update, 18(6), 7-9.

Johnson, D. R. (1991). Formulating a conceptual model of nontraditional student attrition and persistence in postsecondary education programs. Berkeley, CA: National Center for Research in Vocational Education.

Jones, E. (2002). Transforming the curriculum: Preparing students for a changing world, ASHEERIC Higher Education Report (Vol. 29). San Francisco: Jossey-Bass. 
Jordon, J., \& Haines, B. (2003, Summer). Fostering quantitative literacy: Clarifying goals, assessing student progress. Peer Review, 5(4), 16-19.

Jurgens, J. C., \& Robins-O'Connell, C. (2008). A comparitive study of intercultural and global competency opportunities on American and Irish campuses. International Education, 38(1) 66-75.

Kelly, G., \& Bazerman, C. (2003). How students argue scientific claims: A rhetorical-semantic analysis. Applied Linguistics, 24(1), 28-55.

King, P. M., \& Mayhew, M. (2002). Moral judgement development in higher education: Insights from the defining issues test. Journal of Moral Education, 31(3), 247-270.

Kleinke, J. (2005). General education focus group report. Office of Analysis, Assessment and Accreditation. Logan: Utah State University.

Kuh, G. D., Gonyea, R. M., \& W1lliams, J. M. (2005). What students expect from college and what they get. In T. E. Miller, \& B. E. Bender (Eds.), Promoting reasonable expectations: Aligning student and institutional views of the college experience (pp. 3464). San Francisco: Jossey-Bass.

Laanan, F. S. (2003). Degree aspirations of two year college students. Community College Journal of Research and Practice, 27(6), 495-518.

Lampert, N. (2007). Critical thinking dispositions as an outcome of undergraduate education. The Journal of General Education , 56(1), 17-33.

Latiner Raby, R., \& Valeau, E. J. (2007). Community college international education: Looking back to forecast the future. New Directions for Community Colleges (138), 5-14. 
Liu, R. (2002, June). A methodological critique of Tinto's student retention theory. Paper presented at the Annual Forum of the Association for Institutional Research, Toronto, Canada.

Lupton, M. (2008). Evidence, argument and social responsibility: first-year students' experiences of information literacy when researching an essay. Higher Education Research \& Development , 24(4), 399-414.

Mackey, T. P., \& Jacobson, T. E. (2004). Integrating information literacy in lower-and upperlevel courses: Developing scalable models for higher education. The Journal of General Education, 53(3-4), 201-224.

Maxwell, W., Hagedorn, L. S., Cypers, S., Moon, H. S., Brocato, P., Wahl, K., et al. (2003). Community and diversity in urban community colleges: Coursetaking among entering students. Community College Review, 30(4), 21.

McClure, G., Rao, A., \& Lester, W. L. (1999, May/June). Comparing student perceptions of general education and personal growth outcomes at HBCU and non-HBCU institutions. Paper presented at the Annual Forum of the Association for Institutional Research, Seattle, WA.

Meyer, J., \& Dwyer, C. (2005/2006). Improving quantitative reasoning through analysis of news stories. International Journal of Learning, 12(6), 165-173.

Miller, B., \& Sundre, D. (2008). Achievement goal orientation toward general education versus overall coursework. The Journal of General Education, 57(3), 152-169. 
Miller, T. E., Bender, B. E., \& Schuh, J. H. (2005). What students expect from college and what they get. In G. D. Kuh, R. M. Gonyea, \& J. M. Williams (Eds.), Promoting reasonable expectations: Aligning student and institutional views of the college experience (pp. 1064). San Francisco: Jossey-Bass.

Monahan, K. (2003). Critical thinking and pedagogy: What is critical thinknig? Retrieved April 12, 2010, from National University of Singapore Centre for Development of Teaching and Learning: http://www.cdtl.nus.edu.sg/ctp/critical.htm

Monroe, A. (2006). Non-traditional transfer student attrition. The Community College Enterprise, 12(2), 33-47.

Muffo, J. (2001, Spring). Focus group: Student attitudes toward the core curriculum. Retrieved October 23, 2009, from Virginia Polytechnic Institute and State University: H:Dissertation $\backslash \mathrm{CH}-2$ Literature Review $\backslash$ Student Perception $\backslash V$ Tech Focus Group Student Attitudes Toward the Core Curriculum.mht

Nora, A., Attinasi, L., \& Matonak, A. (1996). Testing qualitative indicators of precollege factors in Tinto's retention model: A community college student population. In F. Stage, G. Anaya, J. Bean, D. Hossler, \& G. Kuh (Eds.), College students: The evolving nature of research (pp. 174-185). Needham Heights, MA: Simon and Schuster.

Obama, B. (2009, July 14). The Briefing Room-Press Office-Remarks by President on the American Graduation Initiative. Retrieved September 23, 2009, from The White House: http://www.whitehouse.gov/blog/Investing-in-Education-The-American-GraduationInitiative/ 
Ostrander, S. A. (2003). A developmental framework for university civic engagement?

Relationships between local factors and key program components. Applied Developmental Science, 7(2), 112-113.

Pace, C. R. (1979). Measuring the outcomes of college: Fifty years of findings and recommendations for the future. San Francisco: Jossey-Bass.

Pace, C. R. (1984). Measuring the quality of student experiences. Los Angeles: Higher Education Research Institute, Graduate School of Education, University of California Los Angeles.

Pace, C. R., \& Kuh, G. (1999). College student expectations questionnaire: Second edition. Bloomington: Indiana University: Center for the Study of Postsecondary Education Research.

Pace, C. R., \& Kuh, G. (1998). College student experiences questionnaire: Fourth edition. Bloomington: Indiana University: Center for the Study of Postsecondary Research.

Pascarella, E., \& Terenzini, P. (2005). How college affects students. San Francisco: Jossey-Bass.

Path, B. R., \& Hammons, J. O. (1999). General education in community colleges: A time for reexamination. Community College Journal of Research and Practice, 23(5), 467-480.

Paul, R., \& Elder, L. (2009). Defining critical thinking. Retrieved April 12, 2010, from Foundation for Critical Thinking: http://www.CriticalThinking.org

Perlman, B., \& McCann, L. (1993). The place of mathematics and science in psychology education. Teaching Psychology, 20(4), 205-208.

Pierce, W. P. (2005). The year of critical thinking at Prince Georges Community College: An integrated professional development program. New Directions for Community Colleges, (130), 79-85. 
Pinter, M. (2007). Some mathematical elements of a first-year seminar course. PRIMUS , XVII (1), 44-51.

Plata, M. (2008). Beyond undergraduates attitude about a university-wide writing requirement. Journal of Instructional Psychology, 35(4), 365-375.

Prentice, M. (2007). Social justice through service learning: Community colleges at ground zero. Equity \& Excellence in Education, 40(3), 266-273.

Provasnik, S., \& Planty, M. (2008). Community colleges: Special supplement to the condition of education 2008. Statistical analysis report. NCES 2008-033. National Center for Educational Statistics (ED) (ERIC Document Reproduction Service No. ED502349), 65.

Ramaley, J., \& Haggett, R. R. (2005, Winter). Engaged and engaging science: A component of a good liberal education. Peer Review, 7(2), 8-12.

Rockman, I. (2002). Strengthening connections between information literacy, general education and assessment efforts. Library Trends, 51(2), 185-198.

Sacks, P. (2009, Summer). Tearing down the gates: Confronting the class divide in American education. Liberal Education, 95(3), 14-19.

Schuyler, G. (1999). A historical and contemporary view of the community college curriculum. (G. Schuyler, Ed.) New Directions for Community Colleges (108), 3-15.

Scriven, M., \& Paul, R. (2009). Defining critical thinking. Retrieved April 12, 2010, from Foundation for Critical Thinking: http://www.CriticalThinking.org

Sellen, M. (2002). Information literacy in general education: A new requirement for the 21st century. The Journal of General Education , 51(2), 115-126. 
Serotkin, P. B. (2005/2006). The effectiveness of ten years of values education: A case study of a small, private comprehensive institution. International Journal of Learning, 12(9), 155166.

Simmons, A. (2005). Beyond the premedical syndrome: Premedical student attitudes towards liberal education and implications for advising. NACADA Journal, 25(1), 64-73.

Spiezio, K. E., Baker, K. Q., \& Boland, K. (2005). General education and civic engagement: An empirical analysis of pedagogical possibilities. Journal of General Education, 54(4), 273292.

Stahl, V. V., \& Pavel, D. M. (1992). Assessing the Bean and Metzner Model with Community College Data. Annual Meeting of the American Educational Research Association (p. 49). San Francisco, CA: American Educational Research Association.

Steen, L. A. (2004, Summer). Everything I need to know about averages...I learned in college. Peer Review, 6(4), 4-8.

Stephan, K. D. (2003, Fall). How ethics was specialized away. Academic Questions, 16(4), 3140.

Sterns, P. (2004, April 10). Teaching culture. Retrieved April 10, 2010, from Liberal Education: http://www.aacu.org/liberaleducation/le-su04/le-su04feature1.cfm

Storrs, D., \& Clott, L. (2008, March 1). A qualitative study of honor students' learning orientations: The rare liberal scholar. Retrieved August 31, 2009, from College Student Journal:

http://search.ebscohost.com.ezproxy.vccs.edu:2048/login.aspx?direct=true\&db=eric\&AN $=$ EJ816861\&site $=$ ehost-live 
Taylor, T. (2009). Writing program administration at the two year college: Ghosts in the machine. Writing Program Administrators, 32(3), 120-139.

Tierney, W. (1992). An anthropological analysis of student participation in college. Journal of Higher Education, 63(6), 603-618.

Tinto, V. (1975). Dropout from higher education: A theorectical synthesis of recent research. Journal of Higher Education, 45(1), 687-700.

Tinto, V. (1987). Leaving college: Rethinking the causes and cures of student attrition. Chicago: Chicago University Press.

Tinto, V. (1993). Leaving college: Rethinking the causes and cures of student attrition. Chicago: Chicago University Press.

Tsui, L. (1999). Courses and instruction affecting critical thinking. Research in Higher Education, 40(2), 185-200.

Tsui, L. (2003). Reproducing social inequities through higher education: Critical thinking skills as valued capital. Journal of Negro Education, 72(3), 318-332.

Udodvic, D., Morris, D., Dickman, A., Postlethwait, J., \& Wetherwax, P. (2002). Workshop biology: Demonstrating the effectiveness of active learning in an introductory biology course. BioScience, 52(3), 272-281.

Van Gennep, A. (1960). The rites of passage. Chicago: University of Chicago Press.

Zeszotarski, P. (1999). Dimensions of general education requirements. New Directions for Community Colleges, 108, 39-48. 
Appendix A

College Student Expectations Questionnaire (CSXQ)

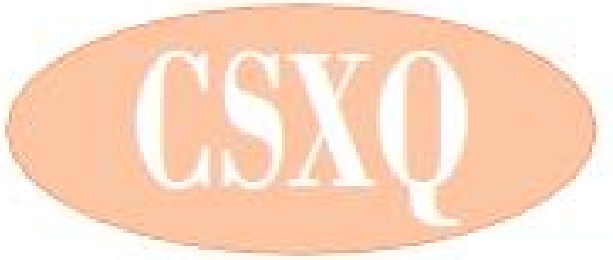

\section{College Student Expectations Questionnaire}

Weicomel

You have not yet experienced life as a student here. But you have some Idess about how you will spend your time, what you will be doing and 80 forth. We are interested in these ideas. More specifically, what do you expect to do thls year as a student? Please complete the Items on the following few pages in a way that answers thls question. It takes less than 15 minutes to complete thls survey.

Your responses are confidentlal. Ke日p in mind that the questionnaire will be read by an electronic scanning device, 80 be careful in marking your responses. Please use a \pm 2 black lead pencil. Marks made by ink pens cannot be scanned. Do not write or make any marks on the questionnalre outside the spaces for your answers. Erase cleanly any responses you want to change.

The benents from thls or any other survey depend on the thoughtful responses of those who are asked to help. Your willingness to perticipate ls very important and very much appreclated. Thank you!

\section{COLLEG ACTIVITIES}

DlitECIKOWS: During the comling year in college, how orten do you expect to do the followinge?

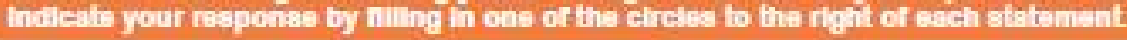

Lbrary and Information Toohnology

Use the lbrary as a quiet place to read ar shocj Ues an inder or databse (compuler, card catalog elt.) to fnd materias on some tople.

Read aselgned materiais other than tertbooks in the Mrary ineserve readings, etc.

Develop a biblography or ast of references for a tem paver or other report.

Use a computer or wond croceseor to prepare reports or papers.

Use email to communicale with an instructor of dasemates.

Participate in dass decussions using an eiectronit medurn (e-mal, lat-serve, chat group, etc) Bearch the World Whse Web or internet for fiformation relsted is a coirne.

Une a compuler to retreve malerlais from a litron not at thes ingtitulton.

Experlencec with Faoulty Ave your indinictor for information related to 3 course you are taking igrades, makeup wort, assigrments, etc.

Discuss your acodemic program or course selection wth a facuity member

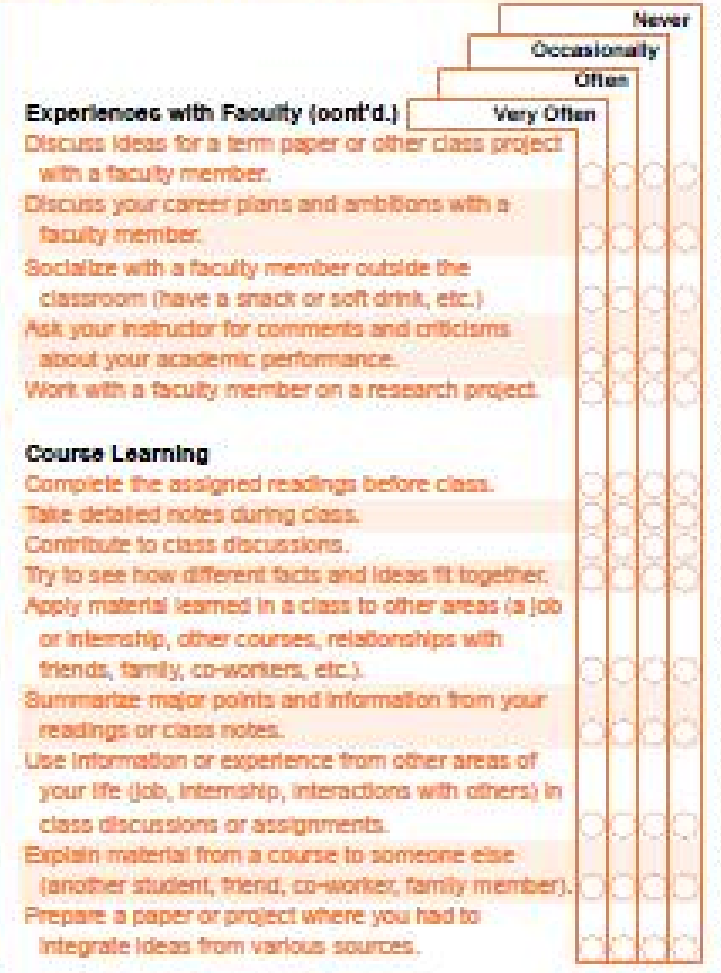

integrate idess from various sourres. 


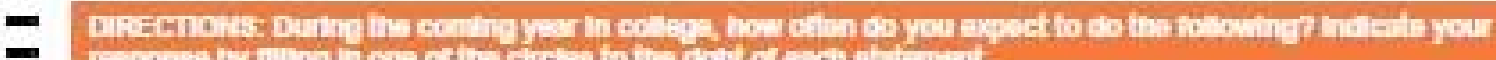

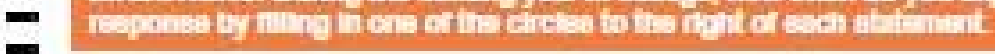

0

- Writing

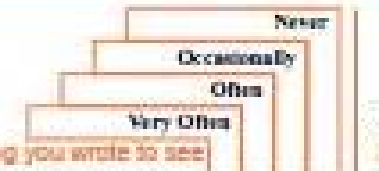

student Aoquaintanoec (cont'd)

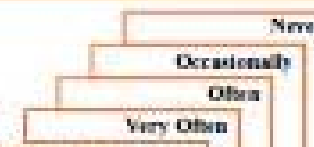

- Aar diner pecpe to read sumething you wrate is as

- itrisclear to ther

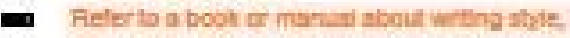
gammar, etc

- Revise a paper or composition two or mare lires

- before yograre satiaffed withe

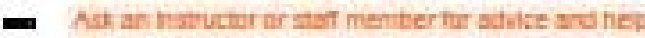

- in improve your witing:

Write a major repont for a cons lad pages or more:

\section{Campuc Foollitioc}

$=$

Oo to sn art exhbtopiery or a play dance or othe theate pertomance, on ur att canpus.

- Alterd a cuncert or other musc evert

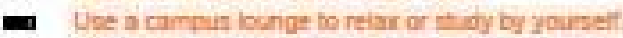

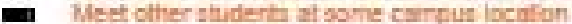

m (canpurs cenie; elic) for a discission.

- Averit a echare or pansi deculation.

- Une a leaming lab or center to

- impreve stuaty ar acadernic shiss ireading.

ne witing eit:

n. Loe recrealional facilites pool, thiness equinmer:

n courta eicy.

- Fay a team nort (iniramura, ciub, miercoleglate)

- Folaw a reguar wohetule of erercise or proctice for

- same recreationa ar woring activity.

\section{a Clubs, Organizatione, Servioe Projeote}

a Niterid a meetine of a camcus cub, organdation.

a or aludent paverument group

- Wort an a carpiz conmines, studert

- aryartiabion, ar service propect ipucilcabonat

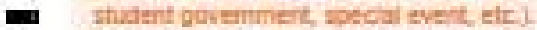

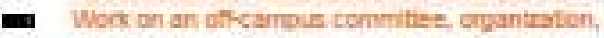

a or service preject inve grap, purch group,

a community everit. etc. i.

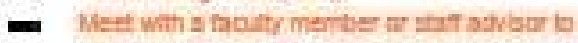

- dscims the activities of a grove ar organiation.

- Mansoe or provide iesdership faran croanizalion

n tor servece praject, on or of the camcus.

\section{a student Acqualntanoes}

- Ifake trends with atuderts whose interests arr

- diflerent torm yours

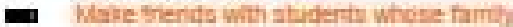

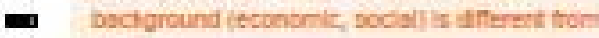

n yours

a Make thends wath students whose race or ethric

m bociground is stterent frim yours

- Have acroue disountions with atudernts whose

n phlicoschy of life or personal values ave wer?

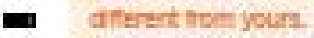

nave serous olecossions with atudents whoss

a relpous beliets are very different from yours

$=$

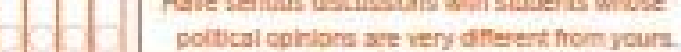

Have serlous docuintons with stardents whose race or edrnic laentncaton is very dneteit ffors yours.

\section{Molentiflo and Quantitative Experienooc}

Mernarte furmuas, defirifins, lechucal iems and conceptr.

Expess a set of reintionshpe uning martematcai terma.

Expain your undersianding af some sderenc or matheriabial theory, princple, w concept in somecne eise (classmate, co-wonter, etc) Rexd articles about scienthc or maheraltex theories or concepts in axtilion ib thnte arsigned foraclase

Complele an expertnent ar poject uning scieminc melhods.

\section{CONVERSATIONS}

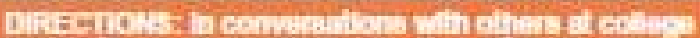

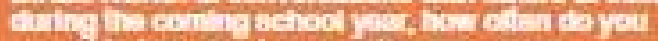

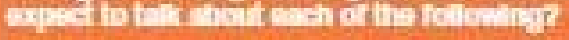

Current events in the newn.

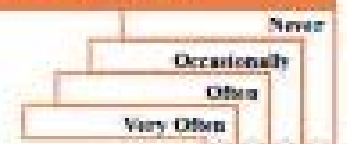

Boclal isues such as peace, justice, human notth equaify, race teatlons.

Diferent Itestylex, cuetomm, and relpions.

The uess and weas of arten, phliosophers. pistertars.

The arts igainting. poetry, Theairical proourbons, dance, aymohony, moviea, elc).

Bcience (fenenes, expetrents, meitrods, etc) Computers and other bechnciogits.

Soclal and entcal laties reiated to sclence and fectriology such as enery, potition, chemras. oenerica, milary ane.

The ecronorry iemplogment, weath, poverty, deht. trade, ete)

imternabonai relabors ithirman ingte , the irade miltary acthentes, polkca difherences, sbi)

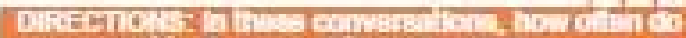

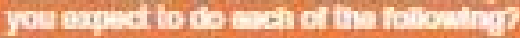

Reter b tnowedoe you armalred in your reading or ciasse:

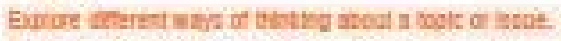
Refer to somethang one of your instructorn sald about a topec or bsue.

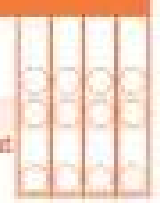




\section{CONVERSATIONS, cont.}

\section{OARECTIONS: In these conversationa, how onten do you expect to do each of the tollowing?}

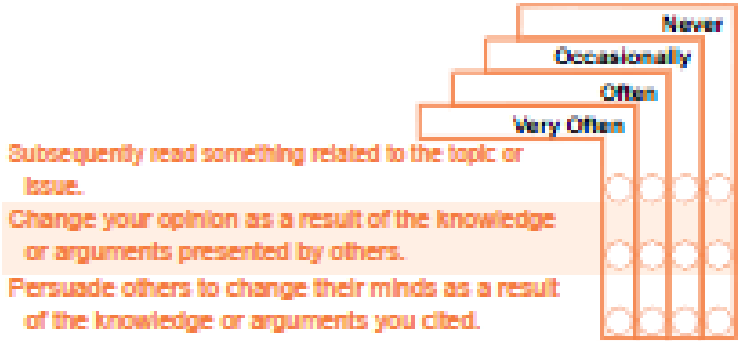

\section{READING/WRITING}

During the comling solhool year, about how much readling and wrting do you axpeot to do? FIII lin one recponce for saoh Item llictod bolow.

Non-aseigned books Textbocks or assigned books

Term papers or other written report: Evesy exama for your coures
Mora then 20 Betrease 11 and 20 Between 6 and 10 Mono

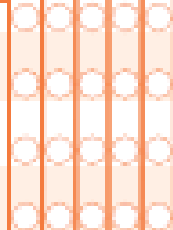

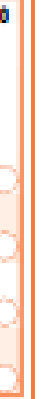

\section{OPINION ABOUT COLLEGE}

How well do you think you will Ike oollege?

O I will be enthusiastic about it:

O I wil ilke it.

O I will be more or less neutral about i.

O I wont like it.

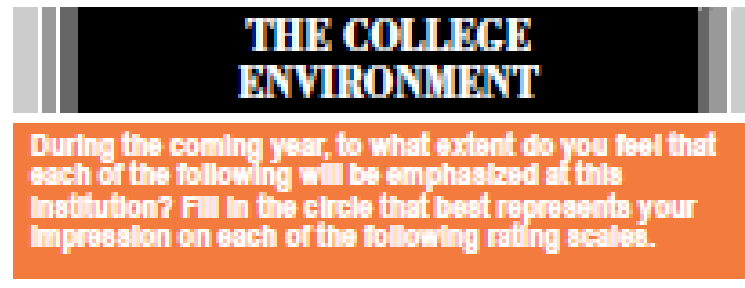

Emphask on developing acadenic, acholaty, and Intelectual qualties strong amphacle (D)(9)(3) (1) Waak omphacle

Emphask on developing aesthelic, expresslve, and creative qualties strong omphack (D) (1) () (2) (2) (1) Waak omphack Emphasls on developing ortical, evalustive, and anshytcal qualties strong omphack 0 (1) (9) (1) Woak emphaclo Emphasis on developing an understanding and appredation of human diversty

strong amphack (D)(D) (D) (1) (1) Wask omphack

Emphasts on developing information Iteracy skils (using computers, other information resources)

strong amphack (D) (6) (2) (2) (1) Woak emphaclo

Emphasls on developing vocational and occupational competence. strong amphack (D)()(2)(1) Wask omphacle

Emphasts on the personal relevance and praclical value of your course: strong amphack (D) (D) (하 (3) (2) (1) Woak emphacle

\section{Tha nast three ratinga reflar to relationehlpg among pacple at thils collage. To whet extent do you feal that each of the

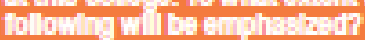

Friendy.

Supportive.

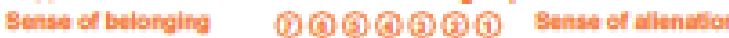

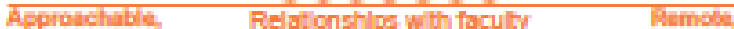

Heloful, members Discouraging.

Understanding. (D)(D)(D)(1) Unsympathefic

Encouraging

Helchil, Consideraie, Relationships wth rogd

Flesible

administrative

Impersonal, Bound

personnel and offices by rogulations

(b)(1) (3) (3) (1)

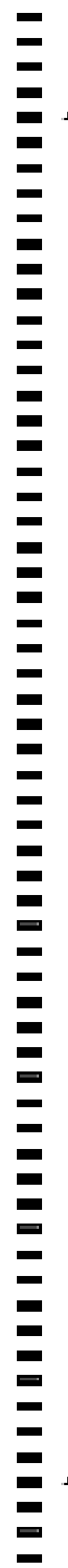

므므 
Where will you llve during thic cohool year?

dormilory or other campus housing inot fratemilytsorority house)

fratemilty or sorority house

O residence (house, apartment, etc.) within walking distance of the instlution

O residence (nouse, apartment, etic.) within difiving distance What do you expeot your college grade point averape to be at the ond of your flret yoar?
OA
O B-, C-
$\mathrm{OA}, \mathrm{B}+$
C, C, or lower

O

Did either of your parentc graduste from college?
no
O yes, mother only.
yes, both parents
dont know

yes, fatiner only

Do you expeot to enroll for an advaneed degree when, or If, you oomplete your undergraduate degree?

Oyes Ono

How many oredit houre will you take thic firet term?
6 orfewer
O $15-16$
7-11
Q $12-14$
O 17 or more

Which of the following oomec olocect to decoribing the neld you oxpoot to major in?

Noriculture

Blologlcalint sclences (blologx, blochenistry, botanx, avologx, eic)

O Bushess (accountho, bushess atrinlatrotion, natiethy manegenent, etc)

Communication (speech, Joumslem, televishonirafle, elc)

Computer and intomition sdences

Oducalion

Engineoting

Elhric, cultural studes, and avea studes

Forelgn langusges and literature (Fiench, Sparleh, elc)

Hesthrelated folds (nurehy, physlcal fherapy, hesth lechnology, etc)

O Hetory

Humartles (Englsh, llersture, phlosophy, religlon, exc)

L Lterallgeneral thudes

Mothenalics

Murinterdeclpinary studles (ntbenstionsi nelistons, ecology. enwionmental studes, etc)

Parts, recieation, letaure studes, sports manspement:

Phyalcal actences (phyalca, chemletry, atronomy, earh adence, elc)

O Pre-podesalonal (pre-dental, pre-medical, preveterhary!

Publk administrablon (clty management, law enforcemert, elc)

sodal sciences (anthopology, ecconomics, poiftcas sclence, peychology. soclology, etc.]

$O$ Vaus and pettming arts (sit, muek, thesles, elc)

Undeclded

$O$ oher: Whap h

During the time cohool ic In cecclon thic coming yosr, about how many hourc a weok do you expeot to epend gutalde of

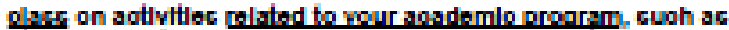
ctudying, writing, resading, lab work, rehesrelng, oto.?

a 05 or fewer hours a week 0 21-25 hours a weelt

6 - 10 hours a week

O 11 - 15 hours a week.

O $16-20$ hours a week

O 25-30 hours a week.

more than 30 hours a week
During the time cohool is In cecclen thic eoming year, about how many hourc a woek do you plan to work on a Job? Fil in one oral in wach oolumn.

nn.

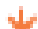
ON-CAMPUS OFF-CANPUS

none; I won't have a job

1 - 10 houre a weak

11 - 20 houre

$21-30$ hours

31 - 40 houre

more than 40 hours

About how muoh of your oollege expencec thic year will be provided by your parente or famlly finoluding your own oontribution|?
all or nearty all
O leas than haif
P more then hal
none or very litie

What le your raolal or ethnlo Identiflostion? (FIII In all that apply)

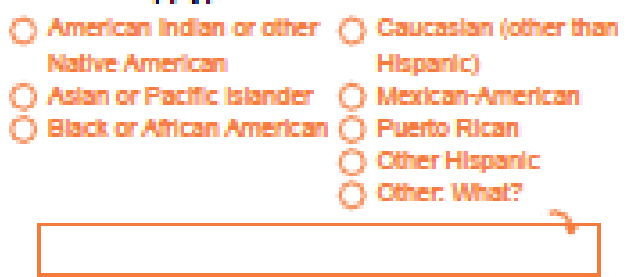

\section{ADDITIONAL QUESTIONS}

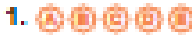

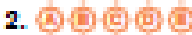

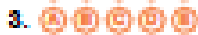
4. (6)(2)
6. (2)(19)(1)
8. (3)(6)(1) (1)
7. (10)(하잉
8. (8)다잉

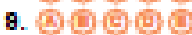
10. @ல@@

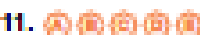

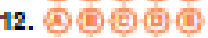

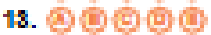
14. (9)@®)

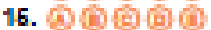
18. (4) (6) (6) (1)

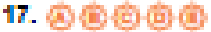

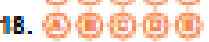

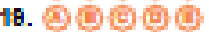
20. 0696

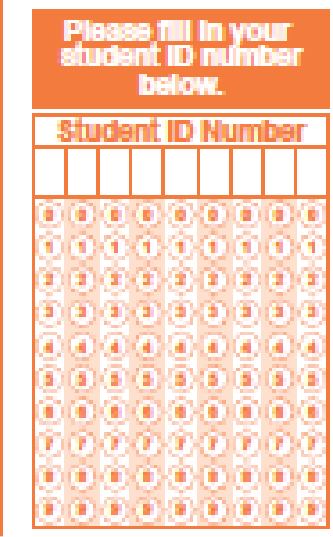

This questunfaire is aveletise fiom the indaria Uriversiny Carter for Pastaecindary Remearol 1000 East Tarth Streat Egarmann Hal Sula 419 Elsomingen N 47456.7512 E-mell ancagindent ed.

Sacund Edisen 1 002

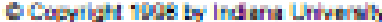
Authos Geuge D Kuh ard c. Roben Pase

\section{THANK YOU}




\section{Appendix B}

Approval for Dissertation Research Study by Participating Institution

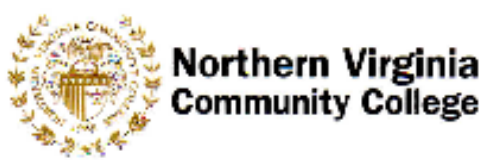

September 7,2010

Ms. Sherri Anna Robinson

6699 Springfield Center Drive

Springfield, VA 22150

Dear Ms. Robinson:

Your proposal to conduct research at Northern Virginia Community College (NOVA) has been approved. This research project will consist of administering the College Student Expectations Questionnaire (CSXQ) to NOVA students. Please ccordinate your research activities with Mr. Brian Foley: Medical Education Campus Provost

Participation in any research project is purely voluntary on the part of students and faculty. Please make sure that the students and faculty are aware of their options.

Please feel free to give me a call if you have any other questions or concerns.

Sincerely

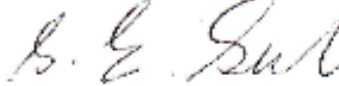

George Gabriel, Ph.D.

Vice President

Office of Institut onal Research, Planning. and Assessment

Cc: Mr. Brian Foley 


\title{
Appendix C
}

\section{Cover Letter to Participants}

\author{
Nest VirginiaUniversity \\ College of Human Resources and Education
}

\author{
September/October 2010
}

Dear Student:

My name is Sherri Anna Robinson and I am a doctoral student at West Virginia University. If you are 18 years of age or older, I invite you to complete the College Student Expectations Questionnaire (CSXQ), a survey about what students expect from their college experience. The survey takes about 15 minutes to complete, and results will be used by faculty and administrators at Northern Virginia Community College (NOVA) to improve the college experiences of students in First Year Experience (FYE) programs. This is a research study and the results will be included in my doctoral dissertation at West Virginia University (WVU).

The West Virginia University's Institutional Review Board (IRB) has acknowledgement of this study on file. The primary investigator of this research study is Dr. Elizabeth Jones. She is a Professor in the Department of Educational Leadership Studies in the College of Human Resources and Education at West Virginia University. Her contact information is 26506-6122.

Your participation in this study is voluntary; you may refuse to participate or withdraw without penalty (class standing). You may skip any question that you do not choose to answer and may discontinue at any time. Your responses will remain confidential and no information associated with your name will ever be released publicly. Please do not provide your Student ID Number at the end of the survey. You must be 18 years or older in order to participate.

If you have questions about this study or the procedures used, you may contact me at 703-8226546 or at srobinson@nvcc.edu.

I thank you very much for your time and attention.

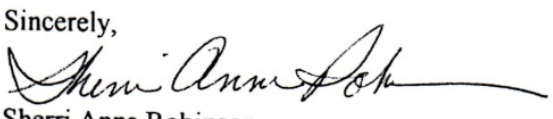

Sherri Anna Robinson

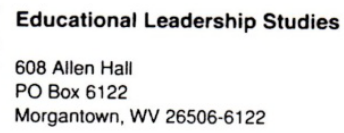

Equal Opportunity/Aftirmative Action Institution

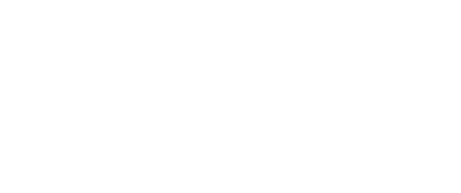

